\title{
TWENTY NEW SPECIES OF FIFTEEN GENERA OF THE AFROTROPICAL SPHAEROCERIDAE (DIPTERA)
}

\author{
LÁSZLÓ PAPP
}

H-1182 Budapest, Beremend u.43, Hungary. E-mail: flyer.papp@gmail.com

Twenty new species of fifteen genera of the Afrotropical Sphaeroceridae are described and illustrated in two subfamilies Achaetothorax mahunkaorum sp. n. (Kenya) and Norrbomia paragravis sp. n. (R.S.A.) in Copromyzinae and Ceropterella mirifica sp. n. (Namibia), Elachisoma simillimum sp. n. (R.S.A.), Gonitella inornata sp. n. (R.S.A.), Gonitella structuralis sp. n. (D.R. Congo), Minilimosina (M.) selecta sp. n. (R.S.A.), Minilimosina (Svarciella) rohaceki sp. n. (R.S.A.), Nudopella erratica sp. n. (R.S.A.), Nudopella marshalli sp. n. (R.S.A.), Nudopella pseudoperta sp. n., (R.S.A.), Paraminilimosina similis sp. n. (Tanzania, Nigeria), Parapoecilosomella formosa sp. n. (D.R. Congo), Philocoprella africana sp. n. (R.S.A.), Phthitia incognata sp. n. (R.S.A.), Phthitia (Kimosina) vulgaris sp. n. (R.S.A), Piliterga africana sp. n. (Nigeria, Tanzania), Setositibiella secunda sp. n. (Burundi), Spelobia foldvarii sp. n. (Tanzania), Terrilimosina improvisa sp. n. (Congo) in Limosininae. New records are provided for some other species. With 173 original figures.

Key words: Sphaeroceridae, Copromyzinae, Limosininae, 15 genera, 20 new species, Afrotropical region

\section{INTRODUCTION}

Along the preparation of the chapter of Sphaeroceridae for the Manual of Afrotropical Diptera (PAPp \& RoHÁčEK 2017), we met the problem despite the effort made on the group for the various biogeographical regions (for the apterous and brachypterous genera, see PAPP \& RoнÁč́K 2017), that the knowledge of the family is still rather uneven. We are now much ahead than when HACKMAN (1965) published his chapter on the Sphaeroceridae of South Africa. Nevertheless, the status now is still not satisfactory. Speciesrich genera have been revised at earlier stages (Ischiolepta, Lotobia, genera of Copromyzinae (but Dudaia), Bifronsina, Chaetopodella, Coproica, Leptocera, Opacifrons, Paralimosina, Poecilosomella), while some others have been revised most recently (Dudaia, Ceroptera, Pseudocollinella). There are several speciose genera (Aptilotus, Minilimosina, Pullimosina, Rachispoda, Spelobia, Spinilimosina, Trachyopella) that still wait for revision. In addition, there are several genera not assigned for the Afrotropical region for which we have material available. The species of these genera are described here, together with some others, for which only the type-species was previously known. In this paper 20 new species of 15 sphaerocerid genera of the subfamilies, Copromyzinae and Limosininae are described and illustrated. 


\section{MATERIAL AND METHODS}

This paper is based on studies of many double mounted - mostly minuten pinned specimens of sphaerocerid from the Sub-Saharan Africa. Part of the material belongs to the HNHM, particularly so, which had been captured by soil traps yellow pan traps, were kept in $70 \%$ ethanol for a period of time. Almost all of them are faded and some body parts are wrinkled after pinning and drying.

The types and other specimens are housed in the: Diptera Collection of the Department of Zoology, Hungarian Natural History Museum, Budapest (HNHM); Institut Royal des Sciences Naturelles, Brussels (IRSNB); Namibian National Insect Collection, State Museum, Windhoek; National Museum of Bloemfontein - Nasional Museum wa Setjhaba (BMSA); Department of Natural Sciences, KwaZulu-Natal Museum, Pietermaritzburg, R.S.A. (NMSA). Other institutes of importance are: Entomologie, Muséum National d'Histoire Naturelle, Paris, France (MNHN); Muséum Royal d'Afrique Central, Tervuren, Belgium (MRAC).

All specimens from the Bloemfontein Museum bear a blue label “Entomology Dept., National Museum P.O. BOX 266, Bloemfontein 9300, South Africa". All specimens from Namibia bear a second blue label "Namibian National Insect Collection, State Museum, P.O.Box 1203, WINDHOEK, Namibia". The data from these labels are not repeated along the descriptions, except for holotypes. For terminology, abbreviations, and techniques of genital preparation, preservation, etc., see PAPP (2008a). In the data of examined material, label data are quoted letter by letter; hand-written label data are given between quotation marks, whereas my annotations of label data are in square brackets. Data on subsequent labels are separated by a "_..

\section{TAXONOMY}

\section{Achaetothorax mahunkaorum sp. n.}

(Figs 1-7)

Holotype male (HNHM): KENYA: Shimba Hills Nat. Park, 2003. 02. 20-25., leg. Mahunka S.[ándor] - Papp L.[ujza].

Paratypes (HNHM): 2 males (one of them with gen. prep.): same label data.

Size (in mm): body length 1.96 (holotype), 1.75-2.00 (paratypes); wing length 1.78 (holotype), 1.56-1.69 (paratypes); wing width 0.60 (holotype), 0.60-0.64 (paratypes).

Description. Male. Head all shiny black, most parts with fine hachure, except frontal triangle and a postocular area. First flagellomere dirty yellow, pedicel and scape grey with some yellowish hue. Arista bare, $0.53 \mathrm{~mm}$ long. Inner vertical seta medium long, $0.13 \mathrm{~mm}$. Gena with strong longitudinal hachure, narrowest (below eye) width $0.10 \mathrm{~mm}$, longitudinal axis of eye $0.35 \mathrm{~mm}$. Genal seta short, $0.04 \mathrm{~mm}$. Clypeus large. Prothorax small, hardly discernible in dorsal view, 1 pprnt, 2 reclinate $n p, 1-1$ pre- and post-sutural sa ( $i a$, the latter small), $1 \mathrm{pa}$ (large, $0.24 \mathrm{~mm}$ long). No kepst. Apical sc $0.41-0.42 \mathrm{~mm}$, basal sc $0.23 \mathrm{~mm}$ long. Legs mostly black, fore coxa and trochanter, base of fore tibia and fore tarsomeres $2-5$ yellow. Male mid trochanter normal (without conical ventroapical lobe), slightly extended ventrally. Mid coxa and trochanter as well as basal $2 / 5$ to half of mid femur yellow. Mid tarsus dirty yellow. Hind coxa, trochanter, basal $1 / 3$ of hind femur, tarsomeres $3-5$, yellow. Hind femur strongly thickened with usual antero- and postero-ventral short setae 
and an anteroventral row of short thick thorns (pegs). Hind basitarsus not modified. Wing membrane hyaline, veins ochrous [holotype's yellow due to fading on alcohol). Halter wax yellow.

Abdominal sternite 5 (Figs 1-2) much broader than long, with sparse long setae, including a pair of very long sublateral-subapical setae of $0.15 \mathrm{~mm}$. Sternite 5 with a medio-

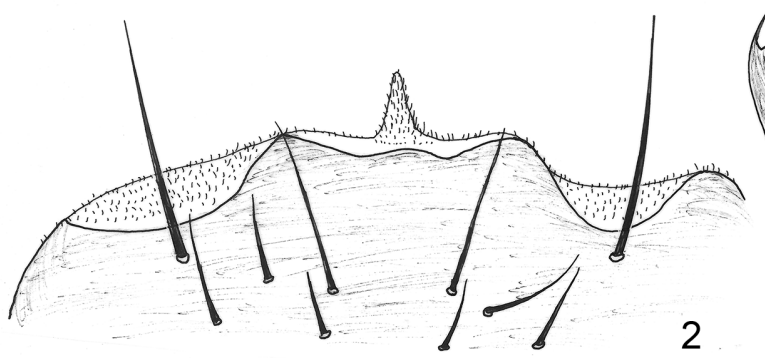

2
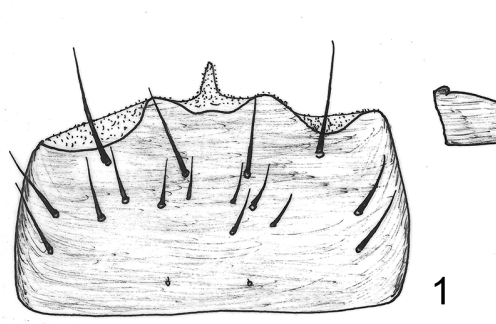
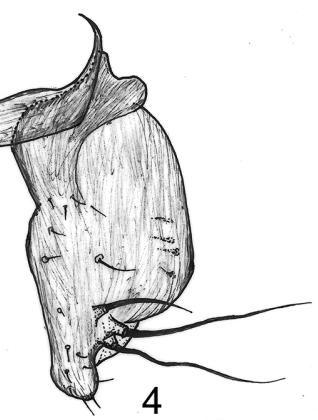

4
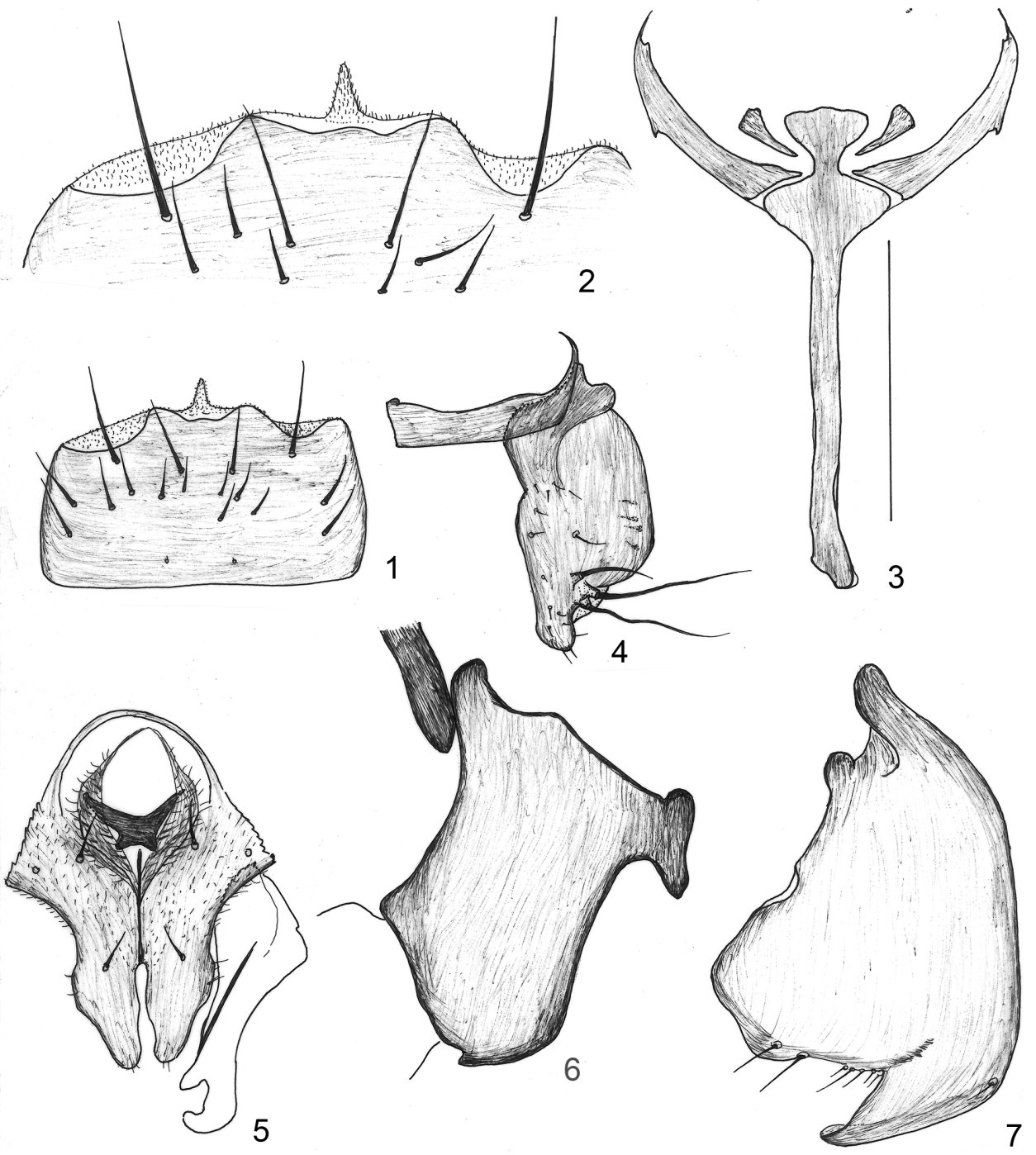

Figs 1-7. Achaetothorax mahunkaorum sp. n., male sternite 5 and genitalia. $1=$ sternite 5 , ventral view, 2 = caudal half of sternite 5 in higher magnification, $3=$ hypandrium, ventral view, $4=$ surstylus and caudal part of hypandrium, lateral view, $5=$ anus, subepandrial sclerite and cerci, caudal view, $6=$ basiphallus with base of phallapodeme, lateral view, $7=$ postgonite, in broadest extension (sublateral view). Scale bar: $0.4 \mathrm{~mm}$ for Fig. 1, $0.2 \mathrm{~mm}$ for Figs 2-5, $0.1 \mathrm{~mm}$ for Figs 6-7 
caudal narrow and sharp process, though less sclerotised. Male genitalia (Figs 3-7) characteristic with robust, apically rounded cercus (Fig. 5). Hypandrium (Fig. 3) large, with long medial apodeme and narrow arms. Surstylus (Fig. 4) short, broad in lateral view, apex almost sharp in caudal view (Fig. 5), thorn rather small. Basiphallus (Fig. 6) robust with a booth-shaped ventro-caudal process. Postgonite (Fig. 7; paramere of PAPP \& NorRBom 1992) broad with widely rounded caudal edge and a short broad (much narrowing), caudally no sharp ventral process.

Female. Abdominal sternite $2-5$ evenly sclerotised. Longest seta of tergite 5 at margin, $0.20 \mathrm{~mm}$. Cercus with two long down curved setae plus one medium size seta besides several shorter, straight, hair-like setae.

Etymology. I named this new species after the collectors: the late Mrs Mahunka (née Lujza Papp) and the late Prof. Dr. Sándor Mahunka.

Comments. This species runs into couplet 9 in Norrbom and PAPP's (1994) key, where it would go into a third case, wing with microtrichose area entirely covering cells $r_{2+3}$ and $d$, and only part of basal cells is non-microtrichose. The male genitalia are peculiar, with its surstylus short and broad bearing a sharp apex and very small thorn.

In the paper comparing of the flies captured on elephant dung and cattle dung in the R.S.A. (PAPP 2008b) one may notice that there I listed a species "Achaetothorax bovinus sp. n.". Studying the specimens again, I came to the conclusion that those specimens are conspecific with $A$. grootaerti, with only minor differences.

\section{Norrbomia paragravis sp. $\mathrm{n}$.}

(Figs 8-24)

Holotype: male (BMSA), sweeping cattle/horse dung - RSA: Free State, Harrismith, Geluhsdal farm at: $27^{\circ} 54^{\prime} 7.05^{\prime \prime}$ S, $29^{\circ} 23^{\prime} 31.9^{\prime \prime}$ E, 9-10.xi.2009, A. H. Kirk-Spriggs - [blue] Entomology Dept. National Museum, P.O.Box 266, Bloemfontein 9300, South Africa BMSA(D) 13395.

Paratypes: 8 males 10 females (BMSA): data same as for holotype; 1 male (HNHM): Eastern Cape Prov., Shamwari Game Reserve, on elephant dung, Jan 11, GPS10, S33 $24^{\prime}$ 47.0" E26 05' 45.0”', 301 m, No. 14, leg. L. Papp \& M. Földvári.

Size (in mm): body length 2.13 (holotype), 1.65-2.75 (paratypes); wing length 2.17 (holotype), 1.67-2.46 (paratypes); wing width 0.80 (holotype), 0.71-0.92 (paratypes).

Description. Male. Frontal triangle with some shine (less dusted), 4 pairs of comparatively short interfrontal setae, shorter than $0.10 \mathrm{~mm}$. Postocellars ca. half ocellars length. Gena with subtriangular bare area below eye, very narrow near vibrissa. Arista rather short: $0.35-0.45 \mathrm{~mm}$ (0.40 $\mathrm{mm}$ on holotype). Mesonotum thickly microtomentose. $1+3$ dorsocentral pairs, acrostichal setae sparse in two regular rows. Katepisternum with a large ventral caudal shiny spot reaching only mid of katepisternum. Wing membrane light brownish, veins light brown. Legs dark, microtomentose, except fore knee and mid basal tarsomeres, dark yellowish. Mid tibia with setae as follow: 2 strong ventro-apical, 2 


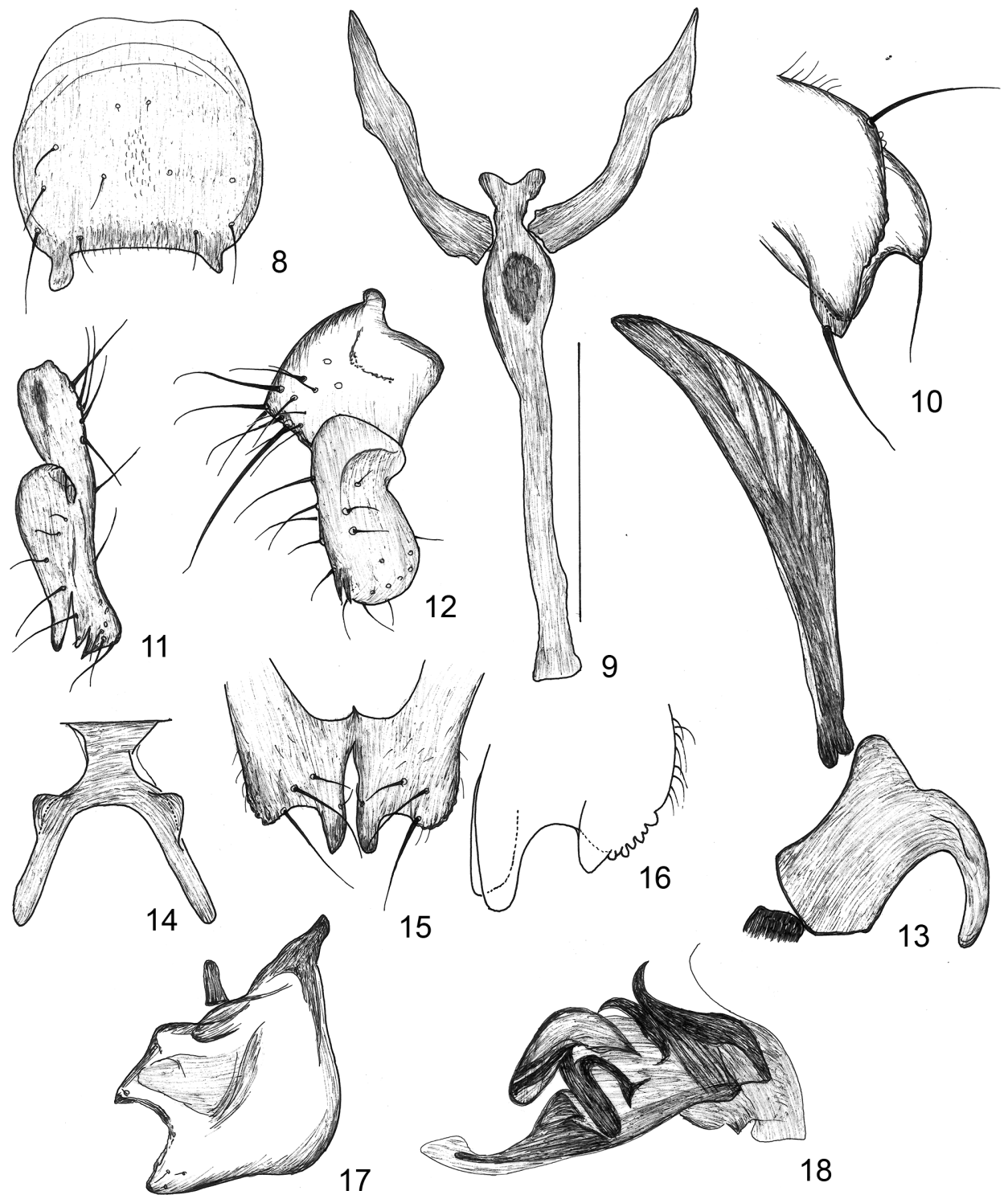

Figs 8-18. Norrbomia paragravis sp. n., male sternite 5 and genitalia. $8=$ sternite 5 , ventral view, $9=$ hypandrium, ventral view, $10=$ cercus and apex of epandrium in high magnification, lateral view, $11=$ surstylus in caudal view, $12=$ surstylus, inner (medial) view, $13=$ basiphallus and phallapodeme, lateral view, $14=$ subepandrial sclerite, ventral view, $15=$ cerci in caudal view, 16 = contours of cercus and apex of epandrium with apex of subepandrial sclerite, lateral view in higher magnification, $17=$ postgonite in broadest extension (sublateral view), 18 = distiphallus, lateral view. Scale bar: $0.4 \mathrm{~mm}$ for Fig. $8,0.2 \mathrm{~mm}$ for Figs 9, 11-15, $0.1 \mathrm{~mm}$ for Figs 10, 16-18 


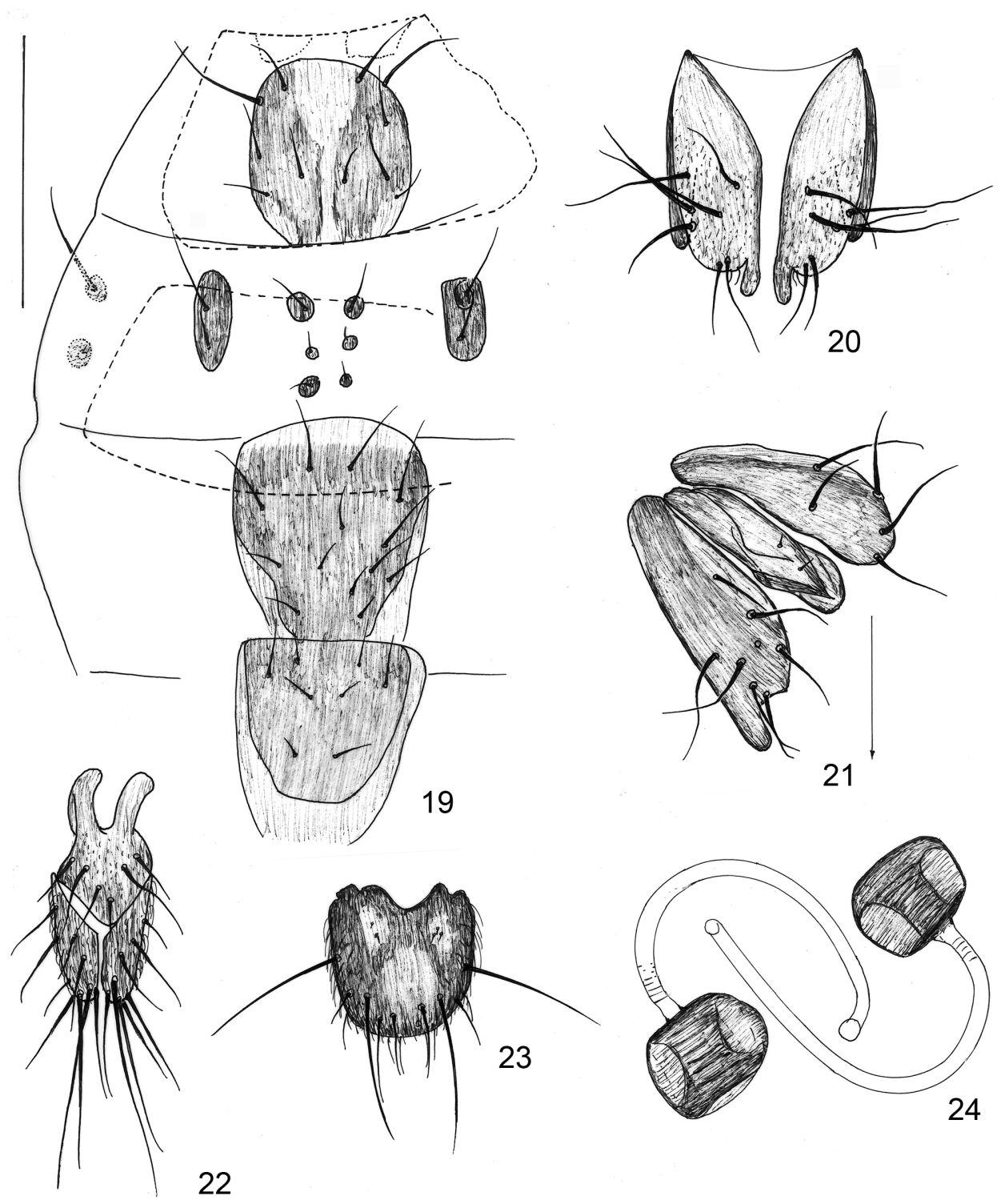

Figs 19-24. Norrbomia paragravis sp. n., female postabdomen and genitalia. $19=$ preabdominal sternites, ventral view, $20=$ sternite 8 , ventral view, $21=$ tergite 8 and sternite 8 , lateral view (arrow: positioning to body axis), 22 = epiproct and cerci, dorsal view, 23 = hypoproct, ventral view, 24 = spermathecae. Scale bar: $0.4 \mathrm{~mm}$ for Fig. 19, $0.2 \mathrm{~mm}$ for Figs 20-23, 0.1 mm for Fig. 24 
anterior apical, a medium-long anterodorsal at $2 / 3$, and a preapical anterodorsal as well as a posterodorsal at $5 / 6$. Hind tibia with a large $(0.21 \mathrm{~mm})$ long curved ventral spur, with a long $(0.20-0.22 \mathrm{~mm})$ anterodorsal seta at $7 / 9$ and a $0.20-0.21 \mathrm{~mm}$ long dorsal preapical seta.

Preabdominal tergites not particularly small, with thick light microtomentum: sternite 4 c. $1 / 4$ as broad as opposite tergite, sternite 3 c. $1 / 5$ as broad as opposite tergite. Sternite 5 (Fig. 8) shield-shaped, about as long as broad (28:30) with a caudal sublateral pair of processes $0.06 \mathrm{~mm}$ long, out of the plane of sternite though not perpendicular to it. Sides of sternite 6 and 7 rather large. Postabdominal sclerites moderately shiny. Hypandrium (Fig. 9) rather long, medial part (rod, continued to apex of caudal process) $0.37 \mathrm{~mm}$, arms (from rod to lateral apex) $0.21 \mathrm{~mm}$. Subepandrial sclerite (Fig. 14) with a trapezoid base and with a pair of digitiform ventral processes. Cercus (Figs 10, 15-16) bilobed, medial lobe with a blunt cranial and caudal process each, lateral lobe subtriangular. Surstylus (Figs 11-12) actually short, very broad, with rounded apex, with rather few setae, but two apical teeth. Phallapodeme (Fig. 13) rather high for its diameter. Basiphallus (Fig. 13) with an extremely large (but not thick) anteriorly curved caudal process. Distiphallus (Fig. 18) with complex shape: a dorsally curved black sub-basal process and an anteriorly curved blunt medial process; apex not sharp. Postgonite broad (Fig. 17) medial part broadly lengthened, actually not ventral process, since ventral edge broader than sub-basal part but apex not protruding.

Female. Sternite 4 (Fig. 19) with peculiar shape, mostly membranous, a pair of elongated lateral sclerites, three pairs of round mesial sclerites sclerotised. Sclerites 6 to 8 strongly shiny. Sternite 8 (Figs 20-21) divided in two parts, deeply protruding (in some specimens almost perpendicularly); ventral part with a narrow apically rounded process. Hypoproct (Fig. 23) shield-shaped, with 2 pairs of very long setae. Epiproct (Fig. 22) small, with a pair of basal, anteriorly directed processes, body of epiproct triangular, with 3 pairs of partially asymmetrical setae. Cercus (Fig. 22) regular, with two pairs of long apical setae and several pairs of medium to long setae subapically and laterally. Spermathecae (Fig. 24) not globular, definitely shorter than broad with a cylindrical mesal part and a lateral cavity; no hairs or scales on spermathecae.

Comments. N. paragravis sp. n. is a quite peculiar species, although it has all diagnostic features of Norrbomia listed by PAPP (1988: 394). In PAPP's (1988) key, it meets a conflict at couplet 1 , mesonotum thickly microtomentose. Our species has $4(1+3)$ dorsocentral pairs. The high number of strong dorsocentral setae is shared with $N$. gravis, but it differs from $N$. gravis (Adams) due to its mat (microtomentose) mesonotum. N. gravis has mostly 5 pairs of dorsocentrals. As for the male genitalia, the new species is easily separated from the remaining species due to its bilobed cercus.

Etymology. The specific epithet of this new species ('paragravis' = beside gravis) refers to its relation to $N$. gravis (Adams).

\section{Ceropterella mirifica sp. $n$.}

(Figs 25-33)

Holotype: male (BMSA), Namibia, TSUMKWE DIST., $3 \mathrm{~km} \mathrm{~N}$ of Kano Vlei, 19 $17^{\prime}$ $15^{\prime \prime} \mathrm{S} 20^{\circ} 21^{\prime} 03^{\prime \prime}, 19 . x i i .1998$, A.H. Kirk-Spriggs, Marais \& Mann, at light dry woodlands 
- [blue] Namibian National Insect Collection, State Museum, P.O.Box 1203, WINDHOEK, Namibia.

Paratypes (BMSA): 2 females: same data as for holotype; 1 male (HNHM, abdomen and genitalia prepared and kept in a plastic microvial with glycerol, right wing prepared between 2 pieces of cover glass): ibid., RUNDU DIST., $20 \mathrm{~km}$ E Rundu, 17 55' 46' ${ }^{\circ} \mathrm{S} 19^{\circ} 58^{\prime}$ 43", 17-18.x.1999, Kirk-Spriggs Pape Hauwanga, Malaise trap sample - 2).

Size (in mm): body length 3.41 (holotype), 3.3-3.8 (paratypes), wing length 3.13 (holotype), 3.48-4.05 (paratypes), wing width 1.40 (holotype), $1.38-1.40$ (paratypes).

Description. Male. Body ratio: head $0.9 \mathrm{~mm}$; thorax $1.3 \mathrm{~mm}$; abdomen $1.6 \mathrm{~mm}$ (body lenght paratype male $3.8 \mathrm{~mm}$ ). A broad epistoma present. Scutum flat, scutellum concave mesally. Anepimeron large bulging (strongly convex), black and shiny. Wing membrane very light greyish yellow, veins yellowish. Second costal section $1.42-1.45 \mathrm{~mm}$, third section $0.70-0.705 \mathrm{~mm}$, costal index 2.00 . Vein $\mathrm{R}_{4+5}$ strongly upcurved, reaching $C$ far $(0.25-0.28$ $\mathrm{mm}$ ) from wing apex. Costal vein fringe about $0.3 \mathrm{~mm}$. Two strong setae $(0.30,0.25 \mathrm{~mm})$ on proximal $C$ to costal break. Costagial setae of $0.30 \mathrm{~mm}, 0.20 \mathrm{~mm}$. Inter-crossvein section of $\mathrm{M}_{1+2^{\prime}} 0.37 \mathrm{~mm}, \mathrm{M}-\mathrm{M}$ crossvein oblique $0.26-0.27 \mathrm{~mm}$, discal cell edged, definitely larger than $90^{\circ}$. Vein $\mathrm{M}_{1+2}$ reaching wing margin, vein appendage of $\mathrm{M}_{3+4}$ visible $0.36-0.37 \mathrm{~mm}$, vein almost reaching wing margin. Anal vein distinct on a section of ca. $0.3 \mathrm{~mm}$. Alula broad, 0.20 $\mathrm{mm}$, broadly rounded apically, cilia $0.15 \mathrm{~mm}$ long, also present on ventral margin of wing.

Abdominal membrane with dense thick setae emerging from dark globular sockets. Tergites 1+2, 3 and 4 reduced; sternites 3 and 4 short, half width of sternite 5 . Width of syntergite $1+2,0.9 \mathrm{~mm}$, length, $0.60 \mathrm{~mm}$. Tergite 5 with 4 pairs of long black marginal setae $(0.35 \mathrm{~mm})$, otherwise tergite 5 with sparse thin seta only, central part bare. Sternite 5 (Fig.

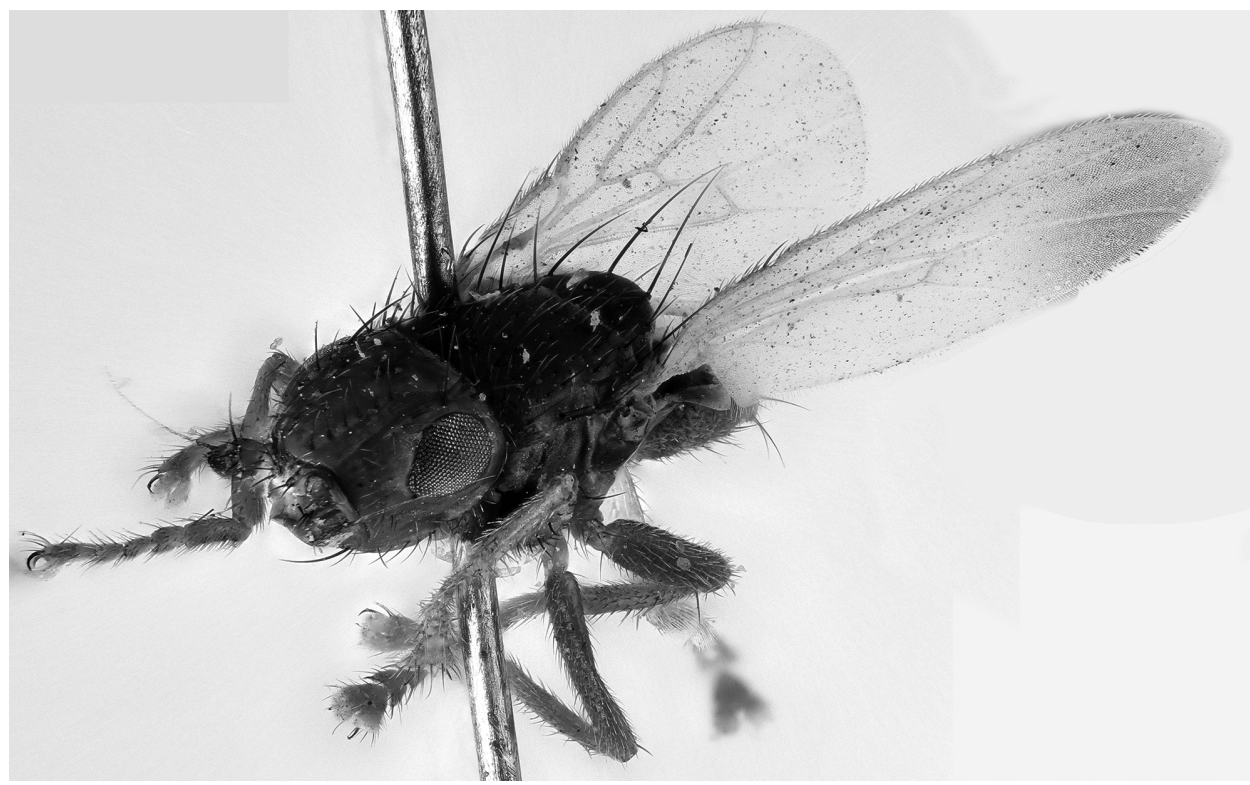

Figs 25. Ceropterella mirifica sp. n., male paratype, subdorsal view (photo: Dr. T. Zatwarnicki) 
26) concave (less broad there when pressed down), mesially bare, medio-caudally with an angulated process. Medio-caudal edge with dense short sharp setae (Fig. 26 outset). Sternite 8 portion dorsally $0.50 \mathrm{~mm}$. Epandrium not large, cercus large, not fused along the sagittal line (Fig. 29). Subepandrial sclerite (Fig. 28) broad rounded, left and right parts

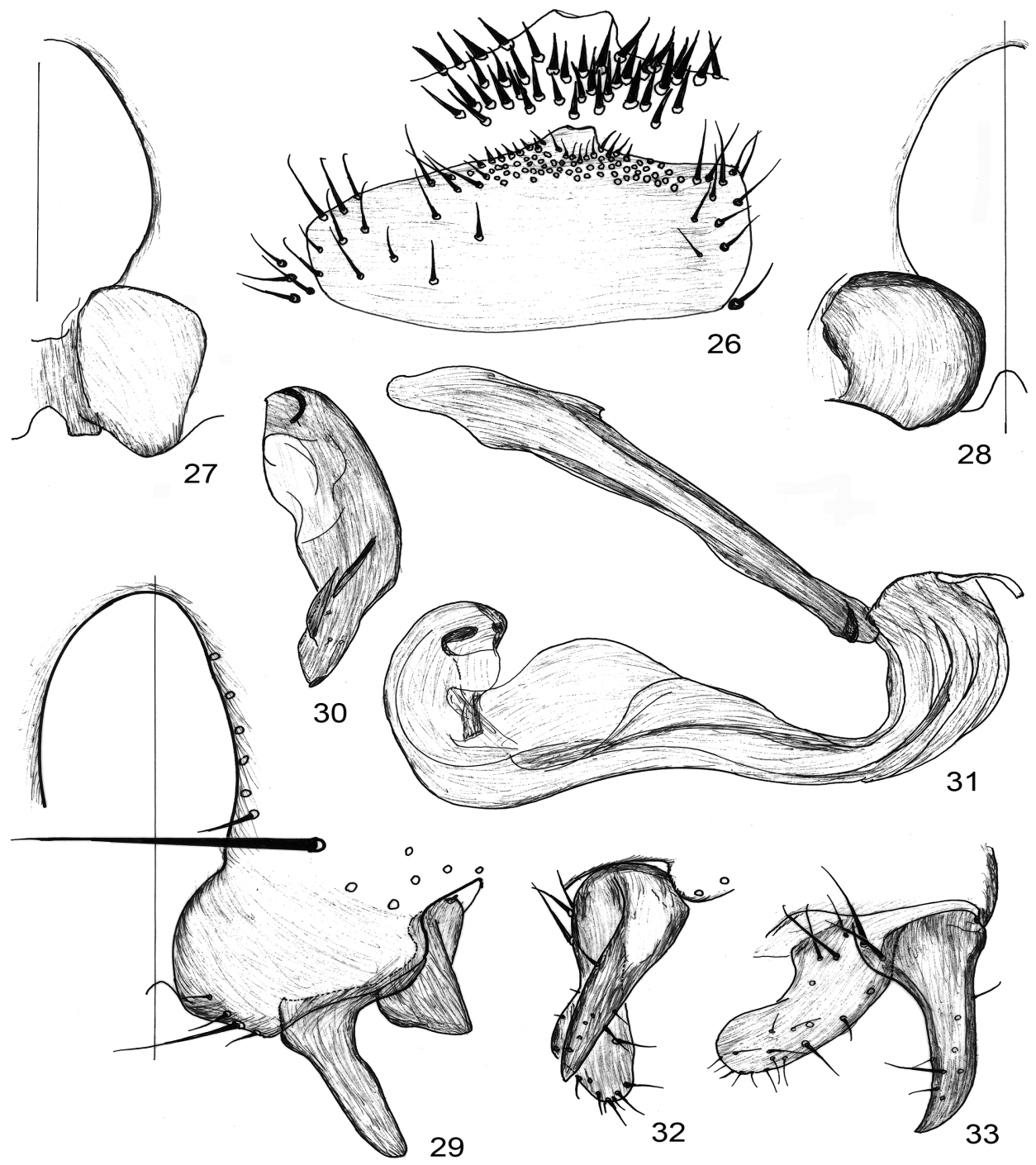

Figs 26-33. Ceropterella mirifica sp. n., male paratype, postabdomen and genitalia. $26=$ sternite 5, ventral view (outset: medial part in higher magnification), 27 = cercal part, ventral view, $28=$ subepandrial sclerite, anterior view, 29 = cercus and surstylus, caudal view, $30=$ postgonite, broadest (sublateral) view, $31=$ phallus and phallapodeme, lateral view, $32=$ surstylus, longest (subcaudal) view, $33=$ surstylus, broadest (sublateral) view. Scale bar: $0.4 \mathrm{~mm}$ for Fig. 26, $0.2 \mathrm{~mm}$ for the rest 
broadly separated. Surstylus (Figs 32-33) divided in two parts (not possible to represent in a single view). Anterior part broadly rounded apically (Fig. 33), posterior lobe slightly longer, with an apex anteriorly. Postgonite (Fig. 30) rather short, with a broad base, narrowing towards apex. Phallapodeme large (Fig. 31, cf. Fig. 35). Phallus not divided into disti- and basiphallus, the line of fusion not detectable (Fig. 31).

Female. Abdominal tergites 3 and 4 membranous with strong setae emerging from dark sockets. Tergite $50.55 \mathrm{~mm}$ long, $0.6 \mathrm{~mm}$ broad, shield-shaped with 2 pairs of $0.35 \mathrm{~mm}$ long lateral and sublateral marginal setae. Postabdomen short, partly telescopic. Hypoproct and epiproct short, cercus with only medium (max. $0.20 \mathrm{~mm}$ ), pale setae.

Etymology. I named this new species as 'mirifica' (wonderful, in Latin) for its vivid colours and conspicuous setosity.

Comments. For a comparison, the male genitalia of C. nitidosa (Richards) - the type species of the genus - were also studied. The phallapodeme in $C$. mirifica slightly larger than in C. nitidosa. The distiphallus is slightly shorter and much higher in lateral view (Fig. 35), narrowing basally (Fig. 34). The phallus is not divided to distiphallus and basiphallus; and this feature may be a strong apomorphy separating it from other Ceroptera species.

\section{Elachisoma simillimum sp. n.}

(Figs 36-42)

Holotype: male (HNHM), RSA: Eastern Cape Prov., Sandvlakte Farm nr. Paterson, cattle pasture, cow pats - Jan 12, 2007, No. 18, GPS 11, S3326 $14.2^{\prime \prime}$ E2556 $54.8^{\prime \prime}$, L. Papp \& M. Földvári.

Paratypes (HNHM): 39 males 12 females: same data as for holotype. 2 males: ibid., farmlands nr Happy Lands, Jan 11, S33 ${ }^{\circ} 28^{\prime} 38.1^{\prime \prime}$ E25 $5^{\circ} 35^{\prime}$ 49.7', $51 \mathrm{~m}$ (No. 15, on cattle

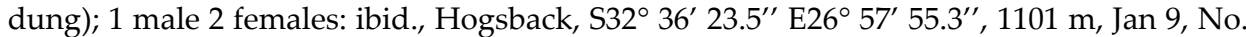
11 (cattle dung); 16 males 17 females: ibid., Shamwari Game Res[erve], on elephant dung,

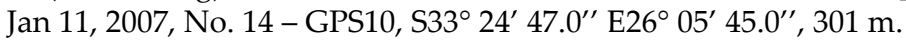

Size in mm: body length 0.71 (holotype), $0.70-0.75$ (paratypes); wing length 0.675 (holotype), $0.67-0.73$ (paratypes); wing width 0.30 (holotype), $0.30-0.31$ (paratypes).

Description. Male. Head as broad as thorax $(0.30 \mathrm{~mm})$, sub-pentagonal in dorsal view. Facial plate short, antennal foveae deep, 6-7 pairs of short interfrontals, a complete row of inclinate inner orbitals. Longitudinal axis of eye $0.105 \mathrm{~mm}$. First flagellomere subconical. Arista $0.24-0.25 \mathrm{~mm}$ with long cilia. Legs short, thick. Mid tibia with a mid ventral seta and a ventro-apical seta, as well as a distinct antero-apical. Mid basitarsus as long as 2 nd tarsomere $(0.06 \mathrm{~mm})$. Mid tibia with anterodorsals at 11/34, 23/34 and 14/17. No posterodorsal seta on mid tibia. Hind tibia with some dorsal setae. Wing membrane light greyish, costal and radial veins light brown, other veins as greyish as membrane. Costa not reaching wing apex. Cs1 with 0.033 long setae. Cs2, $0.125 \mathrm{~mm}, \mathrm{Cs} 3,0.23 \mathrm{~mm}$, costal index 0.54 . Vein $R_{2+3}$ oblique, apical half mostly parallel to costal vein. $R_{4+5}$ arched, apex reaching $\mathrm{C}$ in acute, i.e. not at $90^{\circ}$. Radial index (see Papp 1983), 1.862. Cross-vein M-M, 0.063, RM to $\mathrm{MM}, 0.025 \mathrm{~mm}$. Anal vein kicked. Fringe on margin of wing $0.03 \mathrm{~mm}$. Alula comparatively large, $0.09 \mathrm{~mm}$ broad, apex broadly rounded. 
Genitalia (Figs 36-42) structurally as in E. aterrimum. Sternite 5 (Fig. 36) with broad U-shaped, with a pair of long digitiform lateral processes. That process bears medially directed setae not to long on its medial edge. Sternite 5 meso-caudally with a pair of membranous processes, which serve as base for three rows of small blunt, comparatively long pegs.
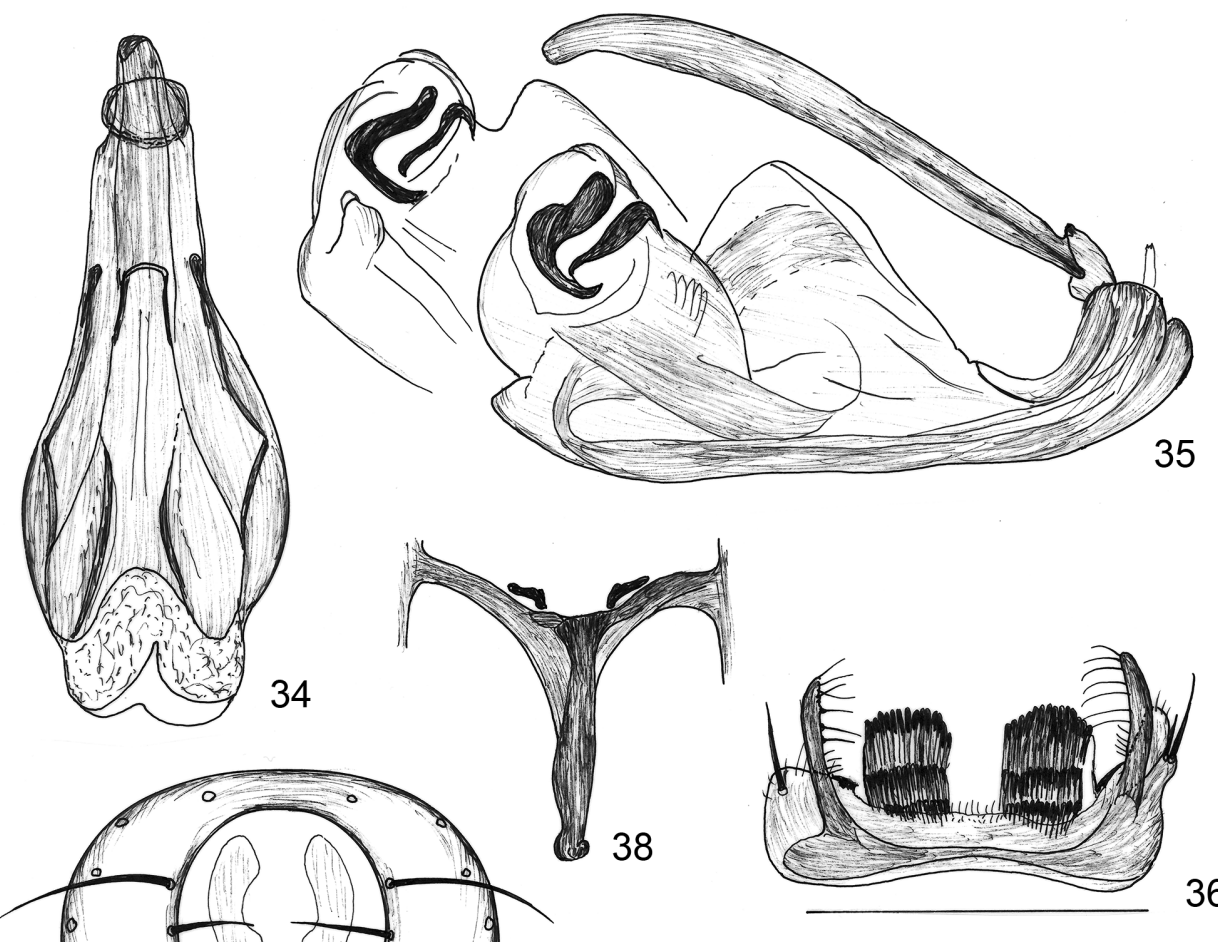

34
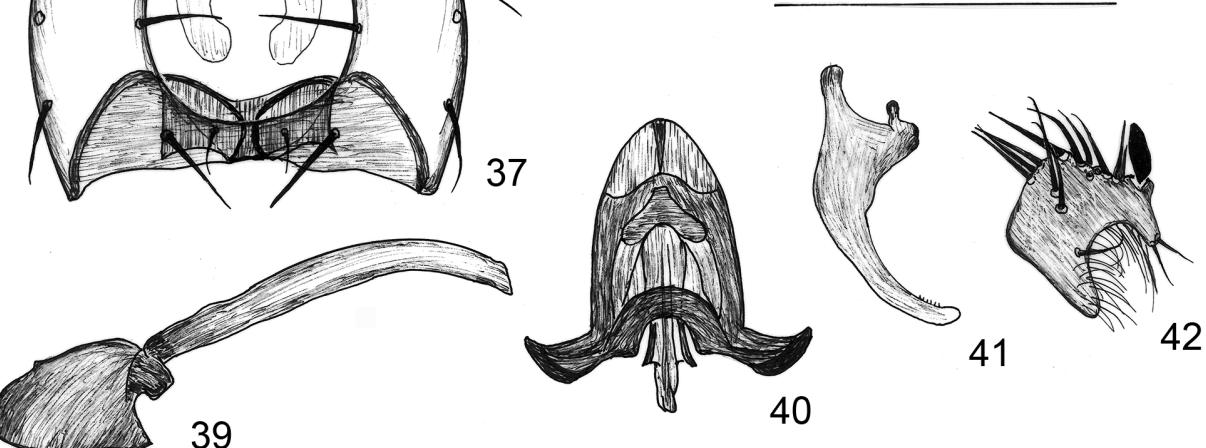

Figs 34-42. 34-35 = Ceropterella nitidosa (Richards), male genitalia: $34=$ phallus in ventral view, 35 = phallus and phallapodeme, lateral view (outset: apex of distiphallus of another specimen). $36-42=$ Elachisoma simillimum sp. n., male postabdomen and genitalia: $36=$ sternite 5 , ventral view, 37 = epandrium with cerci and subepandrial sclerite, caudal view, $38=$ hypandrium, ventral view, 39 = basiphallus and phallapodeme, lateral view, $40=$ distiphallus, ventral view, 41 = postgonite, lateral view, $42=$ surstylus, broadest (sublateral) view.

Scale bar: $0.2 \mathrm{~mm}$ for Figs 34-35, $0.1 \mathrm{~mm}$ for Figs 36-42 
Synsternite not large, left part of sternite 8 convex, right portion to sagittal line very short. Cercal part of epandrium reduced, i.e. ventral edge of cerci almost straight. Subepandrial sclerite small, not projecting dorsally above cercal part (Fig. 37). Hypandrium (Fig. 38) fused to epandrium, hypandrium arms fused with medial appendage; medial appendage (rod) long, reaching tip of phallapodeme in lateral view. Surstylus (Fig. 42) with two 2 lobes, on opposite side with a large black tooth. Phallapodeme slightly curved ventrally. Basiphallus (Fig. 39) compact. Distiphallus (Fig. 40) rather short, apically with a short thin process sagittally, with a pair of broad recurved processes laterally. Postgonite with rather thin apical part, which is definitely proclinate.

Etymology. The specific epithet (Latin: 'simillimum' = most similar) refers to the body features of the new species very similar to those of the wide-spread species E. aterrimum.

Comments. E. simillimum sp. n. is similar to the wide-spread E. aterrimum (Haliday). The radial index of wing venation is smaller than in the $E$. aterrimum - E. bajzae complex, and much lower than that of E. braacki. Reliable differences are in the fine structure of male sternite 5 and those of the male genitalia. The broad processes bearing rows of pegs in this new species are more widely separated (Fig. 36, cf. PAPP 1983: fig. 12). The surstyli are also different in both species: the length of lobes is markedly different from each other in E. aterrimum, while they are almost equal length in E. simillimum. The anal vein is as kicked as in E. aterrimum.

\section{Gonitella inornata sp. $n$.}

(Figs 43-49)

Holotype: male (BMSA, genitalia prepared), Malaise traps, indigenous forest - RSA:

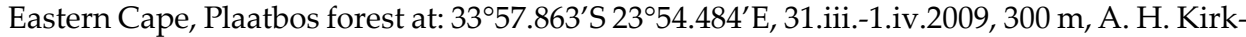
Spriggs \& S. Otto - [blue] Entomology Dept. National Museum, P.O.Box 266, Bloemfontein 9300, South Africa - BMSA(D) 06933.

Size (in mm): body length 1.78 , wing length 1.75 , wing width 0.75 .

Description. Male. Black, subshiny, body strongly sclerotised. Legs black except for yellowish tarsi, three weak pairs of ifr setae. Outer and inner occipitals and postocellar pair of setae are reduced. Anterior fronto-orbitals, $0.05 \mathrm{~mm}$, i.e. comparatively long, pro- and latero-clinate. Gena comparatively broad, $0.08 \mathrm{~mm}$. Vibrissa $0.24 \mathrm{~mm}$. First flagellomere with cilia up to $0.05 \mathrm{~mm}$ long. Arista $0.98 \mathrm{~mm}$, with $0.035-0.04 \mathrm{~mm}$ long cilia. Pedicel setae long, its ventral seta strongly curved, $0.15 \mathrm{~mm}$ from base to tip. Presutural and anterior intra-alar setae, well discernible. Anterior katepisternal seta not discernible, posterior pair normal. Wing membrane light brown, veins ochre. Second costal section $0.69 \mathrm{~mm}$, third section $0.50 \mathrm{~mm}$, ratio 1.375. Discal cell edgy, without vein appendages. Vein $\mathrm{M}_{1+2}$ continuing beyond discal cell halfway to margin as a colourless fold. Alula small. Ventro-apical seta on mid tibia short, no mid ventral seta, but mid tibia with a complete row of short thick black setae ventrally, i.e. no long setae or hairs. Armature of mid tibia: antero-dorsals at $15 / 43$ (strong), 37/43, postero-dorsals at 19/43 (weak), 35/43. Subdorsal setae at 10/43 and $35 / 43$. There is a long dorsal preapical seta on hind tibia. Hind tibia with long dorsal preapical seta of $0.15 \mathrm{~mm}$. 
Sternites 2 to 4 large. Tergite 5 normally developed. Sternite 5 with long caudal marginal setae (Fig. 43), with a large medio-caudal concavity, embracing an intricately sclerotised, divided sclerite (Fig. 44). Sternite $6+7$ portions of synsternite complex, extending to the right side, reaching edge of sternite 8 . Sclerotised parts of penis capsule below sternite 5. Epandrium with a pair of very long subdorsal lateral setae and a pair of long subventral setae. Ventral structures of epandrium symmetric, a flat trapezoid medial part and a ventrally elongated lateral part, with four separate setae (Fig. 45). Hypandrium small, without rod (medial appendage). Subepandrial sclerite (Fig. 45) about as broad as high, dorsally (sagittally) with a deep incision. Surstylus (Figs 48-49) with a transverse body and three lobes: a broad rounded lateral caudal lobe, and a narrower curved, caudally divided, medial lobe with several apical setae, and an anterior lobe with a proclinate large, black blunt ventral thorn. Basiphallus robust, curved in lateral view (Fig. 46), distiphallus small, compact. Postgonite large (Fig. 47), long but without anterior medial process, instead with a blunt caudal process; ventral process small.
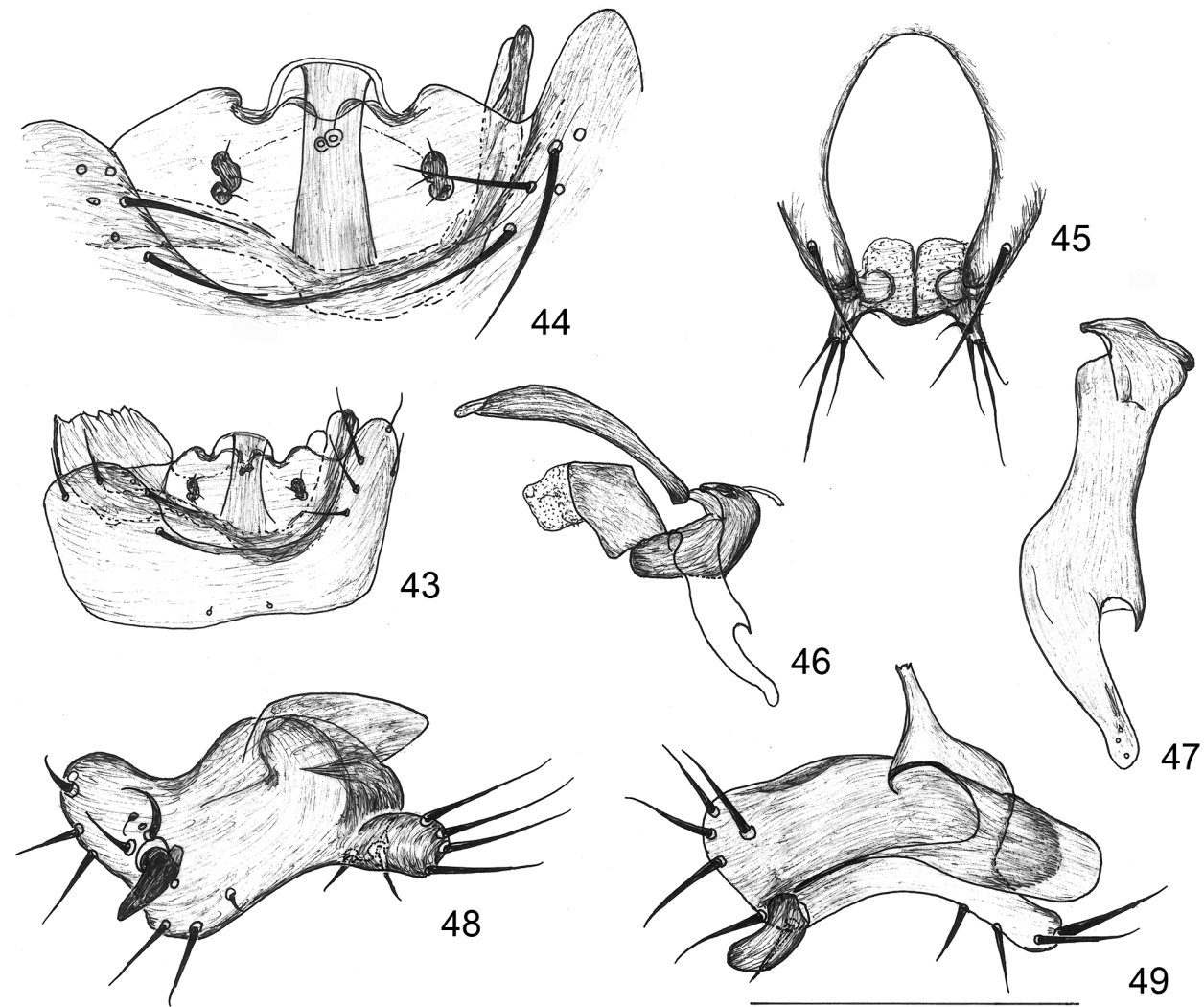

Figs 43-49. Gonitella inornata sp. n., holotype male, postabdomen and genitalia. $43=$ sternite 5 and ventral parts of sternite 6 portion, ventral view, $44=$ same, in higher magnification, $45=$ ventral part of epandrium, cerci and subepandrial sclerite, caudal view, $46=$ phallus and phallapodeme with contours of postgonite, lateral view, $47=$ postgonite, broadest (a sublateral view), $48=$ surstylus, ventral view, $49=$ surstylus, lateral view. Scale bar: $0.2 \mathrm{~mm}$ for Figs 43, 45-46, $0.1 \mathrm{~mm}$ for Figs 44, 47-49 
Etymology. The specific epithet (Latin: 'inornatus' = unadorned, simple) refers to its comparatively simple body and male genital features.

Comments. G. inornata sp. n. is related to the type species of the genus, G. flavipes L. Papp, 2008. Diagnosting features are to be found in the male genitalia (Figs 43-49, cf. PAPp's figs 239-240, 242-247). The anterior fronto-orbitals, as in its congeners, are pro- and lateroclinate. The presutural and anterior intra-alar setae are well discernible, although shorter than in G. structuralis. The alula is small, as in the other species of Gonitella. There is a long dorsal preapical seta on hind tibia, a generic feature of Gonitella. The large size of tergites 2 to 4 is as in G. flavipes. Differently from G. flavipes, the sternite 5 mediocaudal concavity embraces a sclerotised divided sclerite. The robust, curved in lateral view basiphallus is like in G. flavipes. The distiphallus in G. inornata is small and compact, not bifid, as in G. flavipes.

\section{Gonitella structuralis sp. n.}

(Figs 50-59)

Holotype: male (IRSNB), Malaise traps, lowland evergreen swamp forest - D.R. CONGO: Oriental Prov., Eyolo forest, ca. 2 km E. Lieki, 0.69642, 24.24186, 25-29. v. 2010, A.H. Kirk-Spriggs - [yellow] Boyekoli Ebale Congo Expedition 2010 - BECE02373.

Paratypes: 1 male (BMSA, genitalia prepared): ibid., secondary forest - Bomane village area at: $01^{\circ} 16.283^{\prime} \mathrm{N} 23^{\circ} 43.994^{\prime} \mathrm{E} 20-24$. v. - BECE1442; 1 male (HNHM, genitalia prepared): labels same data as holotype, BECE02375.

Size: body length 2.13 (holotype), 2.10, 2.22 (paratypes); wing length 1.71 (holotype), $1.65,1.76$ (paratypes); wing width 0.71 (holotype), 0.70, 0.72 (paratypes).

Description. Male. Head. Three weak pairs of ifr setae. No postocellar seta, outer and inner occipitals minute and very separate from each other. Anterior fronto-orbital slightly proclinate. First flagellomere twice as high as long. Arista very long $(1.00 \mathrm{~mm})$, cilia $0.03-$ $0.04 \mathrm{~mm}$ long; cilia of similar length on slightly conical first flagellomere. Gena narrow, $0.06 \mathrm{~mm}$ below eye. Vibrissa $0.23 \mathrm{~mm}$ long. Scutum with a presutural and a medium-long prealar inclinate seta. Acrostichals in 6-8 unarranged rows. Anterior katepisternal seta inconspicuous, posterior pair $0.20-0.21 \mathrm{~mm}$ long. Wing membrane light brown, as well as veins. Second costal section, $0.54 \mathrm{~mm}$, third section, $0.46 \mathrm{~mm}$, costal ratio 1.16. RM-MM section and M-M crossvein equal, $0.125 \mathrm{~mm}$. Discal cell edged, no vein appendages. $\mathrm{M}_{1+2}$ continuing beyond discal cell halfway to wing margin as a colourless fold. Alula small, very narrow $(0.06 \mathrm{~mm})$, with long cilia apically and medially. Legs yellow, dorsal side of tibiae and femora darker dirty yellow. Dorsal preapical on fore tibia not longer than tibial diameter at that point. A row of strong black setae postero-ventrally on mid femur. Mid tibial armature: anterodorsals at 15/45 (weak), 37/45 (strong), posterodorsals at 16/45 (weak), 36/45 (strong), a weaker sub-dorsal at 33/45, other setae on mid tibia comparatively strong. No mid ventral seta, ventro-apical short $(0.05 \mathrm{~mm})$, some $2-3$ longer ventral setae subapically. Hind tibia with very strong and long dorsal preapical seta of $0.14-0.15 \mathrm{~mm}$ with some long dorsal hairs, up to $0.10 \mathrm{~mm}$. Hind basitarsus swollen, 2nd tarsomere very large, length of tarsomeres 1+2 $0.26 \mathrm{~mm}$, tarsomeres 3-5, $0.21 \mathrm{~mm}$. 
Sternite 5 (Fig. 50) with a definite, broad, with a slightly emarginated medio-caudal extension (contrarily to G. inornata). Synsternite (Figs 51-53) of an extremely intricate shape: sternite 8 portion normal, sternite 7 portion narrow with a blunt curved ventral part, which reaches sagittal plane of the body. Sternite 6 portion with huge anterior lobes, hidden under pregenital sternites (Fig. 52), ventral part with ca. 10 very long setae (Figs 51-53). Medio-caudal part with a sagittal process, directed anteriorly and towards body cavity. Epandrium with 2 pairs of thick blunt setae $0.15-0.17 \mathrm{~mm}$ long plus one even longer seta on the right side. Surstylus is highly structured (Figs 56-59): 3-lobed, anterior one with an anterior peculiar black thorn, at apex of a ventrally curved process; lateral lobe similar to a raptor-bird leg with 4 "talons" (Fig. 58); medial lobe (Fig. 56) broadened caudally, with numerous thin hairs. Body of surstylus rounded caudally (Fig. 59). Phallapodeme (Fig. 54) with a very high dorsal sagittal lamella. Basiphallus (Fig. 54) large and curved, distiphallus very long. No ventral process on border of distiphallus. Postgonite (Figs 54-55) very large, caudally curved, with a shovel-shaped apex and a large caudal process in its apical 2/5.

Etymology. The specific epithet (Latin: 'structuralis' = structured) refers to its intricately 'built' male genitalia.

Comments. There are females of two other species in the collection of the National Museum of Bloemfontein and BECE from D.R. Congo \& Burundi. I am afraid, however, one cannot successfully identify them in possession of larger material from Central Africa. The large and curved basiphallus is as in G. inornata, while the distiphallus is much longer than in G. inornata, more similar to that of G. flavipes (L. PAPP, 2008a: fig. 243). The disti- and basiphallus has no ventral process on the border is as in G. flavipes. In G. structuralis, the sternite 5 has a slightly emarginated medio-caudal extension, contrarily to $G$. inornata.

It is obvious that Gonitella and Setositibiella are related genera. Shared characters of the genera Gonitella and Setositibiella include:

- body strongly sclerotised,

- postocellar seta reduced (hardly or not at all discernible),

- $\quad$ head setae occe and occi small,

- anterior fr-orb seta weak and partly proclinate,

- gena very narrow,

- first flagellomere ca. 2 times higher than long,

- arista extremely long with long cilia,

- $\quad$ anterior katepisternal seta minute or lacking,

- two pair of long $d c$, no prsc,

- $\quad$ no mid ventral seta on mid tibia.

Gonitella species differ, however, from Setositibiella, in having 2 additional setae in the intra-alar row: a presutural one and a prealar one (this later definitely incurved). Differences included in PApP's key (2008a: 188) stand, except for second costal section longer or much longer than third). The main distinctive features are in the male genitalia. 


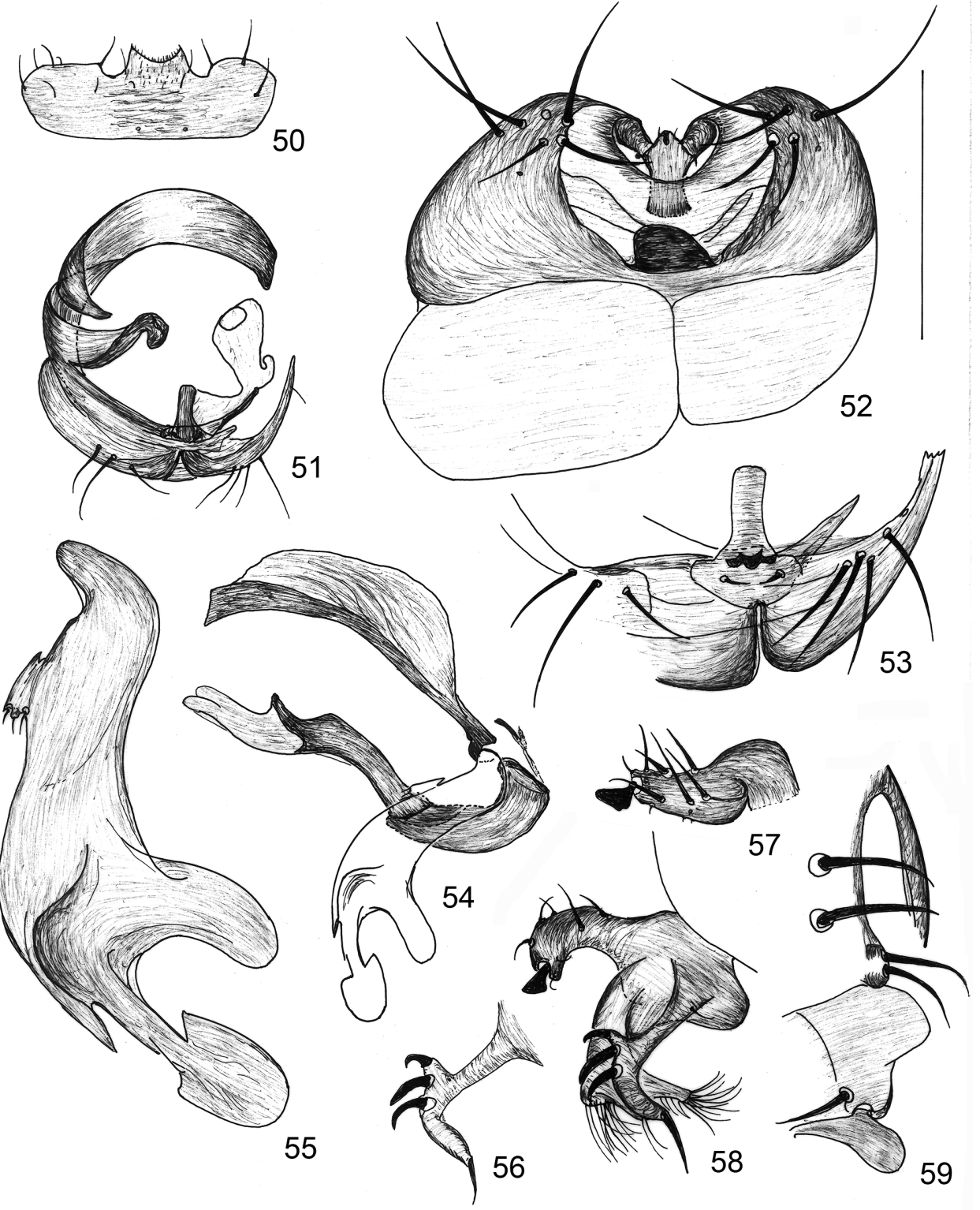

Figs 50-59. Gonitella structuralis sp. n., male postabdomen and genitalia. $50=$ sternite 5 , ventral view, $51=$ synsternite, caudal view, $52=$ ventral parts of synsternite, ventral view, $53=$ ventral parts of synsternite, caudal view, $54=$ phallus and phallapodeme with contours of postgonite, lateral view, $55=$ postgonite, in broadest (sublateral) view, $56=$ surstylus, lateral view, $57=$ anterior lobe of surstylus, anterior view , $58=$ medial lobe of surstylus, broadest (sublateral) view, 59 = posterior part of surstylus with caudal part of epandrium and left cercus, broadest (sublateral) view. Scale bar: $0.4 \mathrm{~mm}$ for Fig. 50, $0.2 \mathrm{~mm}$ for Figs 51-54, 56-59, $0.1 \mathrm{~mm}$ for Fig. 55 


\section{Minilimosina (M.) selecta sp. n. \\ (Figs 60-65)}

Holotype: male (HNHM), RSA: Eastern Cape Prov., Bloukrans Pass, in a side valley, Jan 14-16, 2007, No. 23 - GPS16, S33 57' 09.6" E23 37' 59.4”', 70 m, leg. L. Papp \& M. Földvári.

Paratypes (HNHM, 1 male with genitalia prepared): 3 males, same data as holotype; 1 female: ibid., in a forest nr R102, Jan 15-16, 2007, No. 25 - GPS19, S33 56' 57.3' 'E23 $36^{\prime}$ $20.8^{\prime \prime}, 224 \mathrm{~m}$.

Size (in mm): body length 1.87 (holotype), 1.65-2.08 (paratypes); wing length 1.78 (holotype), 1.60-1.87 (paratypes), wing width 0.77 (holotype), $0.63-0.80$ (paratypes). Description. Male. Entire facial plate and frontal triangle bright black. Scutum and scutellum shiny, black, pleura not shiny. Two pairs of latero-clinate fronto-orbitals, anterior one slightly longer than half length of posterior pair. Parafacialia narrow, with some minute hairs. Lunule large, triangular. Four pairs of moderately long interfrontal pairs. Antenna with minute medial scape seta $(0.035 \mathrm{~mm})$. First flagellomere with long $(0.035 \mathrm{~mm})$ cilia. Arista $0.65-0.70 \mathrm{~mm}$ long with long $(0.025-0.03 \mathrm{~mm})$ cilia. A single pair of longer dorsocentral setae present, second pair slightly anteriorly, $0.08 \mathrm{~mm}$ only; one postpronotal, two notopleural, one long postalar at supra-alar row, one short presutural near to notopleural seta, one long posterior pa and some short intra-alars discernible. One tiny katepisternal seta present. Acrostichals relatively scarce and long, in 6-8 rows between dorsocentrals. Prescutellar seta moderately long. Wing membrane greyish, veins light brown. Costal vein extending beyond tip of $\mathrm{R}_{4+5}$ by $0.15-0.18 \mathrm{~mm}$; Cs2 section, $0.375 \mathrm{~mm}, \mathrm{Cs} 3,0.49 \mathrm{~mm}$, costal index, 0.77 . $R_{2+3}$ largely parallel to costa, apex bent up towards $C$. Discal cell edgy, $\mathrm{M}_{1+2}$ and $\mathrm{M}_{3+4}$ continuing beyond M-M for 0.07-0.09 mm. RM-MM section, $0.15 \mathrm{~mm}$, MM cross-vein $0.14 \mathrm{~mm}$. Alula not very narrow $(0.085-0.09 \mathrm{~mm})$, apex rounded. No mid ventral seta on mid tibia, ventro-apical seta moderately long, no row of thick black setae ventrally on mid tibia. Antero-dorsals on mid tibia at 10/32, 22/32 (weak), 26/32 (large and slightly more dorsal), postero-dorsals seta at 25/32.

Epandrium medium large. Sternite 5 (Fig. 60) twice wider than long, medio-caudally with a long row (comb) of flat black spines (pegs). Cercal area (Fig. 61) short, sagittal fusion very short. Subepandrial sclerite (Figs 61-62) much higher than cercal portion. Surstylus (Fig. 65) broad-based, sub-triangular, with numerous long setae on its caudal part, but without a large black peg; apical part strongly narrowed, bare of setae. Postgonite (Fig. 64) long, slender, with a proclinate apex. Phallapodeme long and slender (Fig. 63), almost straight. Basiphallus rather large and compact. Distiphallus short and high (Fig. 63) apically, with well sclerotised sharp processes.

Etymology. The specific epithet (Latin, 'selecta' = chosen) refers to the fact that I have seen several undescribed species of Minilimosina in materials from the Afrotropical region and I have selected and described one of them in order to demonstrate the occurrence of the genus in the Afrotropical region.

Comments. M. (Minilimosina) selecta sp. $\mathrm{n}$. is an easily recognisable species by its male genitalia. Its surstylus is without a large black peg and its distiphallus has sharp processes apically. I found no species with this kind of character combination among the Palaearctic species. In addition, there is 
a comb of flat black spines medio-caudally on male sternite 5 . The cercal area with a very short sagittal fusion is as in some other species of Minilimosina (see e.g., RoнáčEK 1983, fig. 253). The rather large compact basiphallus is also as in numerous species of M. (Minilimosina) (see Roнáčé 1983, figs 243, 275).

\section{Minilimosina (Svarciella) rohaceki sp. $\mathrm{n}$. \\ (Figs 66-72)}

Holotype (HNHM): male, RSA: Eastern Cape Prov., Bloukrans Pass, in a side valley, Jan 14-16, 2007, No. 23 - GPS16, S33 57' 09.6"' E23 37' 59.4', 70 m, L. Papp \& M. Földvári.

Paratypes (HNHM): 1 male and 5 females: same data as holotype; 1 female: ibid., Hogsback, in a park, No. 8, Jan 8-9, 2007 - GPS05, S32 35' 18.0”' E26 56' 56.0”', 1298 m.
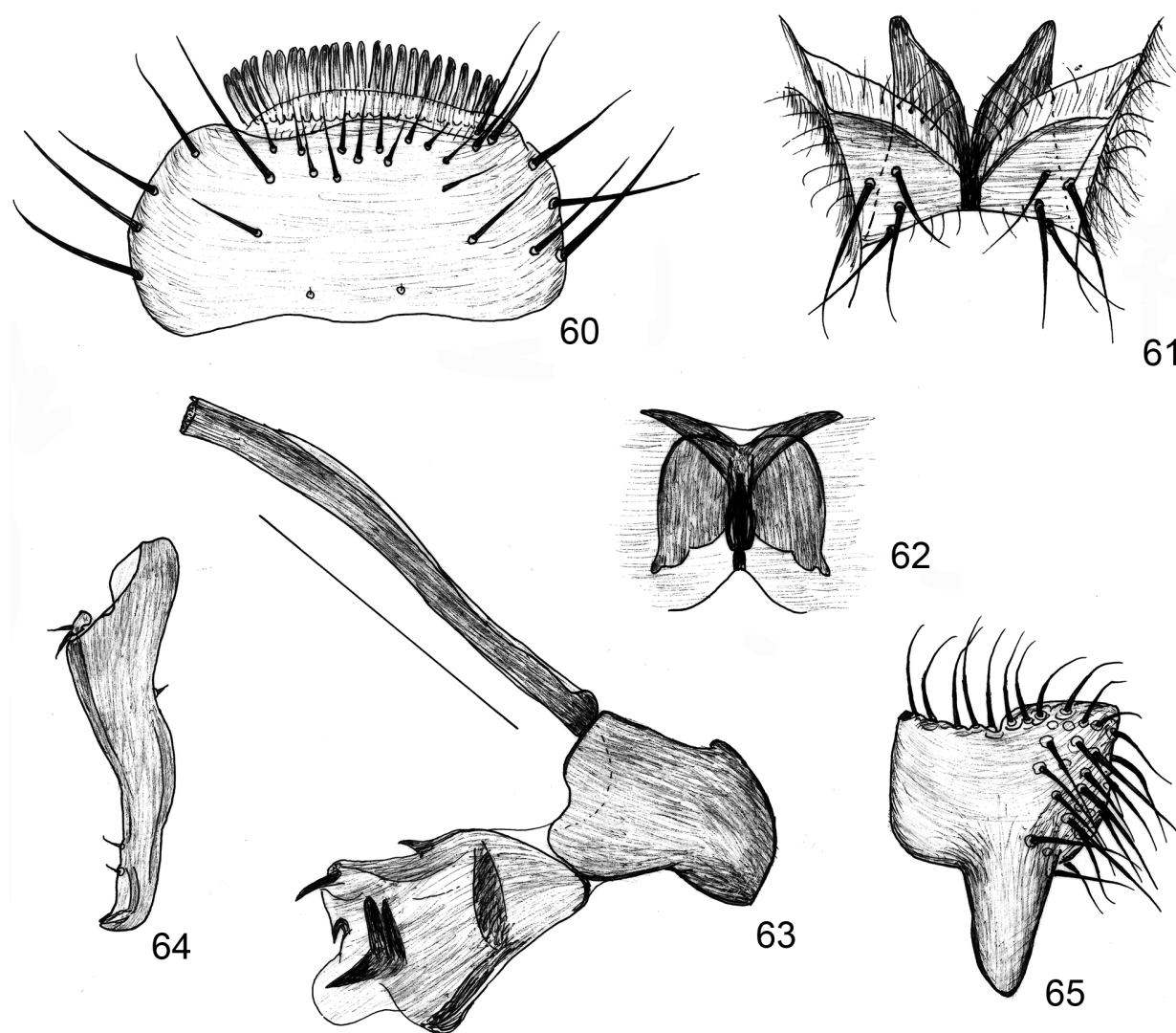

62

63

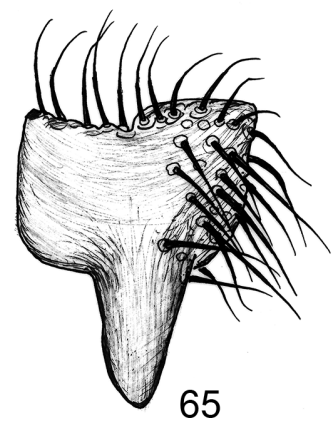

Figs 60-65. Minilimosina (M.) selecta sp. n., male postabdomen and genitalia. $60=$ sternite 5 , ventral view, 61 = cerci and epandrial sclerite, ventral view, $62=$ subepandrial sclerite, anterior (!) view, 63 = phallus and phallapodeme, lateral view, $64=$ postgonite, lateral view , $65=$ surstylus, broadest (sublateral) view. Scale bar: $0.2 \mathrm{~mm}$ for Fig. 60, $0.1 \mathrm{~mm}$ for Figs 61-65 
Size (in mm): body length 1.90 (holotype), 1.88-2.10 (paratypes); wing length 1.80 (holotype), 1.75-2.04 (paratypes); wing width 0.71 (holotype), 0.70-0.78 (paratypes).

Description. A beautiful species with shiny black body and bright yellow legs. Head 0.33 (0.31-0.34) $\mathrm{mm}$ long, facial plate definitely convex in lateral view. Parafacialia very narrow and with extremely thin white hairs. Posterior fronto-orbital very strong $(0.175-$ $0.19 \mathrm{~mm}$ ), anterior pair thin and only $0.08 \mathrm{~mm}$. Frontal vitta shiny black. Interfrontal seta minute, only 2 (3) pairs most anteriorly. Ocellar, outer and inner vertical pairs strong, occipitals and postocellars not developed. Vibrissa $0.20-0.22 \mathrm{~mm}$ long, peristomals $0.08 \mathrm{~mm}$ or shorter. Genal seta fine, $0.10 \mathrm{~mm}$, several short genal setae also discernible. Scape minute, pedicel large, longer than 1st flagellomere, with a wreath of long apical setae, longest one is the ventral one $(0.11 \mathrm{~mm}$, dorsal one $0.10 \mathrm{~mm})$. First flagellomere more conical with a distinct (though not sharp) dorsal apex. Arista very long, $0.74-0.79 \mathrm{~mm}$, its cilia only $0.02 \mathrm{~mm}$ long, or somewhat less. Anepisternum and katepisternum are without any shining black spots. Two pairs of very long dorsocentrals, postpronotal short and thin, 2 notopleurals (posterior pair on a callus), 1 long supra-alar, post-alar and prescutellar pairs hardly or not differentiable from thoracic small setation. Apical scutellar seta $0.41 \mathrm{~mm}$ (holotype) to $0.56 \mathrm{~mm}$ (female paratype), basal scutellar seta $0.25 \mathrm{~mm}$ (holotype) to 0.23 $\mathrm{mm}$ (paratype female), both scutellar setae emerging from a small tubercle. Acrostichals thin, not arranged regularly, ca. $6-8$ rows anteriorly. Posterior kepst $0.20 \mathrm{~mm}$, anterior pair minute. Wing membrane light brown, veins (including $\mathrm{C}$ ) ochre. Second / third costal sections: $0.70 / 0.54$, ratio 1.3 . First and second costal sections with longer marginal setae $(0.05$ $\mathrm{mm}$ vs. $0.04 \mathrm{~mm}) . \mathrm{R}_{4+5}$ terminates almost at wing tip. Inter-crossvein section of $\mathrm{M}_{1+2}, 0.20$, $\mathrm{M}-\mathrm{M}$ cross-vein $0.10 \mathrm{~mm}$. Discal cell edgy, $\mathrm{M}_{3+4}$ distinct on a distal section of $0.14-0.15 \mathrm{~mm}$. Alula small, very narrow, narrowly rounded apically with $0.08-0.09 \mathrm{~mm}$ long apical hair. Halter wax-yellow. Legs entirely yellow, except for fore tibia and dorsal apical parts of femora, with some obscure brownish hue. Mid tibia with a moderately long antero-dorsal at 18/41 and at 33/41 each, a longer subdorsal at 14/41, a large subdorsal at 35/41, a posterodorsal seta at 33/41. Ventro-apical seta of mid tibia short and thick. Hind tibia with a $0.10-0.11 \mathrm{~mm}$ long dorsal preapical seta.

Abdomen long, almost as long as head and thorax combined. Male sternite 5 (Fig. 66) medio-caudally with a long sagittal process, without short setae. The body of sternite 5 is without a comb of flat black spine but with some long setae. Subepandrial sclerite (Fig. 67) rather large and dark. Surstylus (Figs 68-70) broadly bilobed, not possible to represent in a single view: posterior lobe at its broadest is close to a subcaudal view. Postgonite (Fig. 72) well caudal to basiphallus, rather broad, without long setae, slightly broadened on its apical third, apex rounded, apical part with numerous setulae. Phallapodeme (Fig. 71) broadened dorsally. Basi- and distiphallus fused (Fig. 71), widely sigmoid in lateral view, apex membranous.

Etymology. I name this new species to honour Dr Jindřich Roháček (Slezské zemské muzeum Opava, Czech Republic) for his unsurpassable achievements in the taxonomy of Sphaeroceridae and in several other dipterous families, and particularly so for the species of Minilimosina.

Comments. RoháčEK and Marshall's (1988) revision included 27 species of the subgenus Minilimosina (Svarciella), including 14 new ones from the Palaearctic, Oriental, Neotropical and Nearctic regions, including Philippines, Papua New Guinea and the Bismarck Islands, but none from the Afrotropical 
region. This new species from South Africa is characterised by its bare, long sagittal process on its male sternite 5 (Fig. 66), its S-shaped phallus, on the fused basi- and distiphallus (Fig. 71), and large, widely bilobed surstylus (Figs 68-70). The new species is unique also by its anepisternum and katepisternum having no shining black spots. As in $M$. (S.) vitripennis, the male sternite 5 medio-caudally has a long sagittal process.
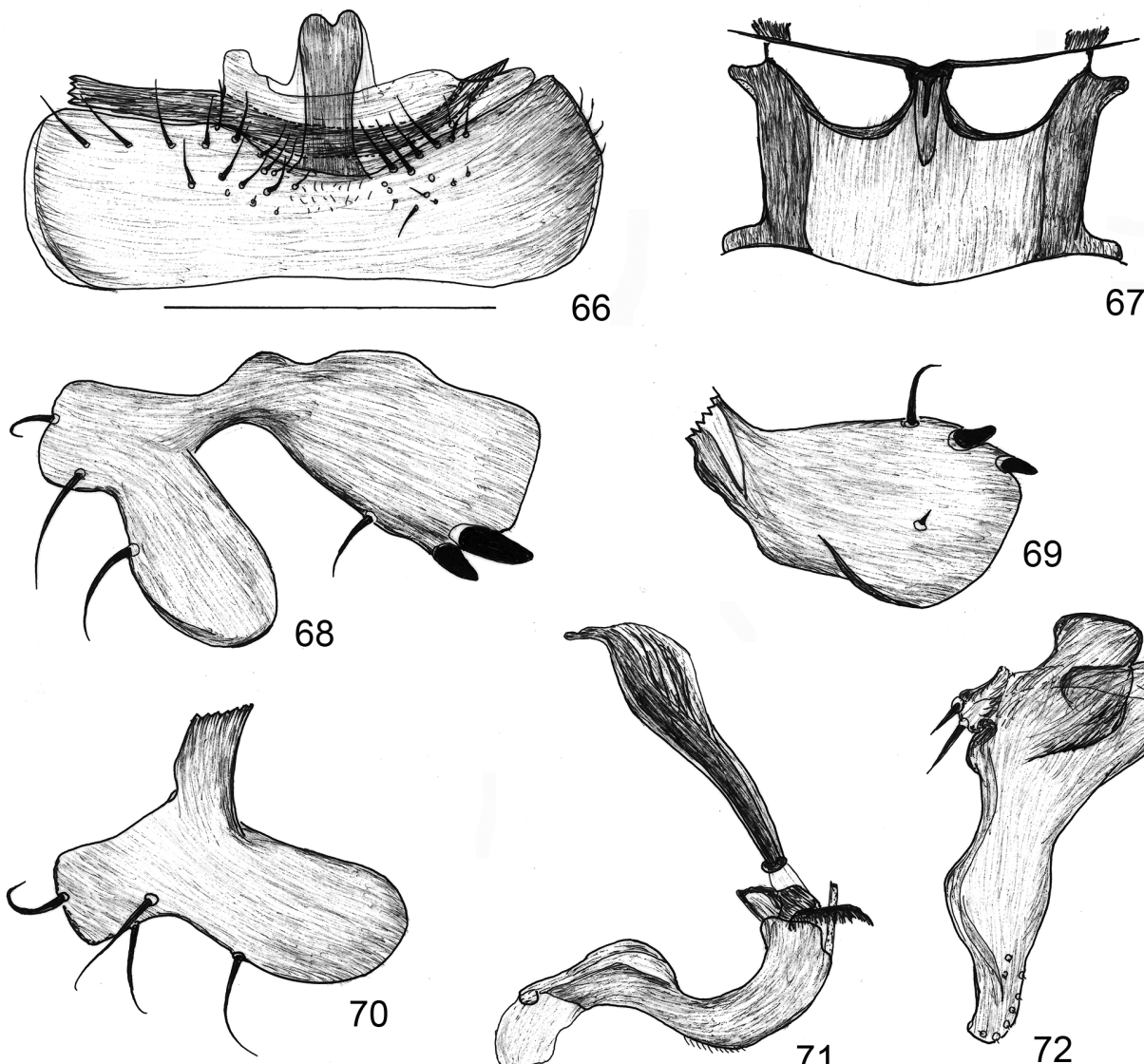

66

67
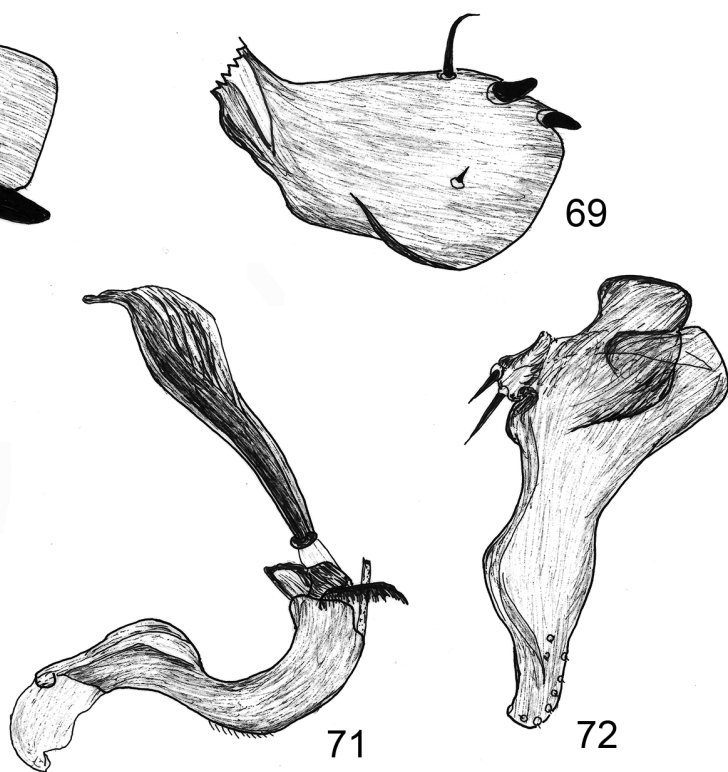

Figs 66-72. Minilimosina (Svarciella) rohaceki sp. n., male postabdomen and genitalia. $66=$ sternite 5, ventral view, $67=$ subepandrial sclerite, anterior view, $68=$ surstylus, broadest view, $69=$ posterior lobe of surstylus at broadest, $70=$ anterior lobe of sursylus, subcaudal view, $71=$ phallus and phallapodeme with base of postgonite, lateral view, $72=$ postgonite, in broadest (sublateral) view. Scale bar: $0.2 \mathrm{~mm}$ for Figs 66, 71, $0.1 \mathrm{~mm}$ for Figs 67-70, 72 


\section{Nudopella erratica sp. n.}

(Figs 73-79)

Nudopella operta: PAPp 2008b, misidentification, not N. operta Roháček et Marshall, 1986

Holotype (HNHM): male, Eastern Cape Prov., Shamwari Game Res[erve], on elephant dung, Jan 11, 2007, No. 14 - GPS10, S33 $24^{\prime} 47.0^{\prime \prime}$ E26 05' 45.0'”, 301 m, L. Papp \& M. Földvári.

Paratypes (HNHM): 4 males, 3 females: same labels as for the holotype; 1 male: Eastern Cape Prov., farmlands nr Happy Lands, on cow and horse dung, No. 15 - Jan 11, GPS 09, S33 ${ }^{\circ} 28^{\prime} 38.1^{\prime \prime}$ E25 $5^{\circ} 35^{\prime} 49.7^{\prime \prime}$, 51 m; 2 females, ibid., Sandvlakte Farm nr Paterson, cattle pasture, cow pats, No. 18, GPS 11, Jan 12, S33 26 $14.2^{\prime \prime}$ E25 $56^{\prime} 54.8^{\prime \prime}$, 300 m; 4 males: ibid., KwaZulu Natal, S Drakensberg, Garden Castle, along Mlambonja River, Jan 22, GPS21, No. 33, S29 44' 59.4" E29 12' 42.1'”, 1811 m; 1 female: KwaZulu Natal: S Drakensberg, Himeville, Thomas Str., compost \& fallen fruits - Jan 22, No. 35, GPS25, S29 $44^{\prime} 36.6^{\prime \prime}$ E29 $30^{\prime} 49.5^{\prime \prime}, 1541 \mathrm{~m}$.

Size (in mm): body length 1.28 (holotype), 1.21-1.67 (paratypes); wing length 1.12 (holotype), 1.12-1.41 (paratypes); wing width 0.57 (holotype), 0.55-0.66 (paratypes).

Description. Gena below eye $0.10 \mathrm{~mm}$, longitudinal axis of eye $0.15 \mathrm{~mm}$. Genal seta much longer than 1st peristomal seta. Longest seta on first costal section $0.09 \mathrm{~mm}$. Halter brown. Other body characters, see under N. marshalli sp. n., including the two parallel rows of short thick setae on mid basitarsus (Fig. 73).

Abdomen $0.9 \mathrm{~mm}$ long. Male abdominal sternite 2 less sclerotised and less than half as broad as sternite 3 . Sternite $30.15 \times 0.40 \mathrm{~mm}$, sternite $40.13 \times 0.43 \mathrm{~mm}$, i.e., wide (abdomen width $0.56 \mathrm{~mm}$ ). Tergite 5 with very long latero-caudal pair of setae. Male sternite 5 (Fig. 74), $0.15 \times 0.43 \mathrm{~mm}$, no setae on medio-caudal membranous area. Synsternite (Fig. 76) ventral part extremely concave, covered by sternite 5 . Only sternite 8 part and a small part of sternites 6-7 portions dorsal. Right half of sternite 6 very narrow, sternite 7 portion mostly curved anteriorly (better seen in caudal view); sternite 8 portion small, max. 0.20 mm wide. Cercus (Fig. 75) wide and broadly rounded ventrally. Subepandrial sclerite (Fig. 78), broad, V-shaped in ventral view, high and its ventral arms laterally curved when seen caudally (Fig. 75). Cercal setae comparatively short. Surstylus (Fig. 79) with an extremely large, wide, medially directed black apical process, without a subapical lobe. Hypandrium small, rod weakly sclerotised. Distiphallus short, with a wide, apical part partly membranous. Postgonite (Fig. 77) rather simple, apical third narrowed, with an anterior apex.

Etymology. The specific epithet (Latin: 'erratica') refers to the erroneous former identification of the specimens now part of the type-series.

Comments. PApp (2008b) misidentified South African specimens of this new species as Nudopella operta Roháček et Marshall, 1986 which is a Korean (most probably an Oriental) species.

This species occurs together with N. pseudoperta sp. n. (see No. 33 above). Its specimens have been found on compost and also on dung of big hoofers. Differently from $N$. pseudoperta, the surstylus has no subapical lobe. 

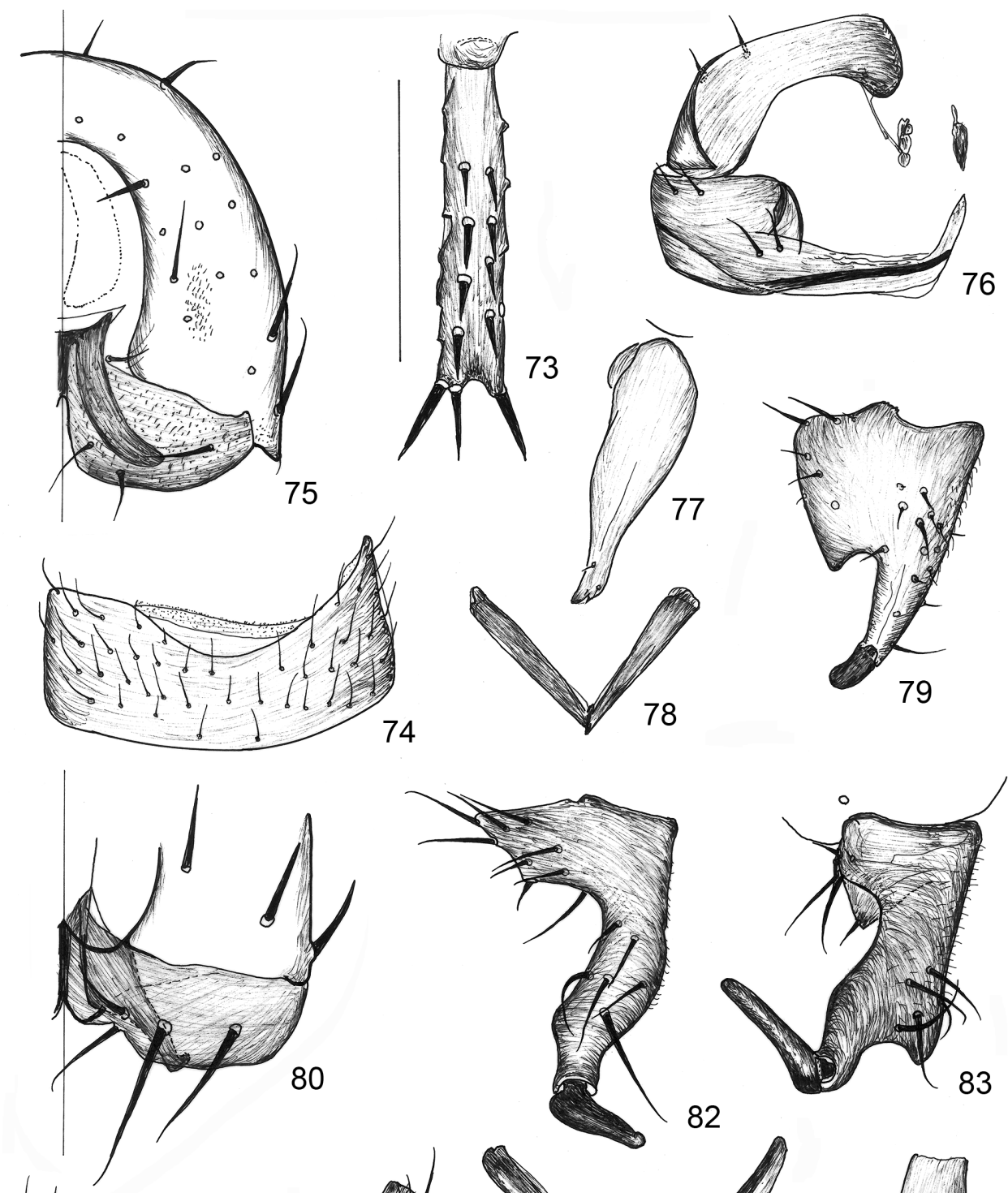

82
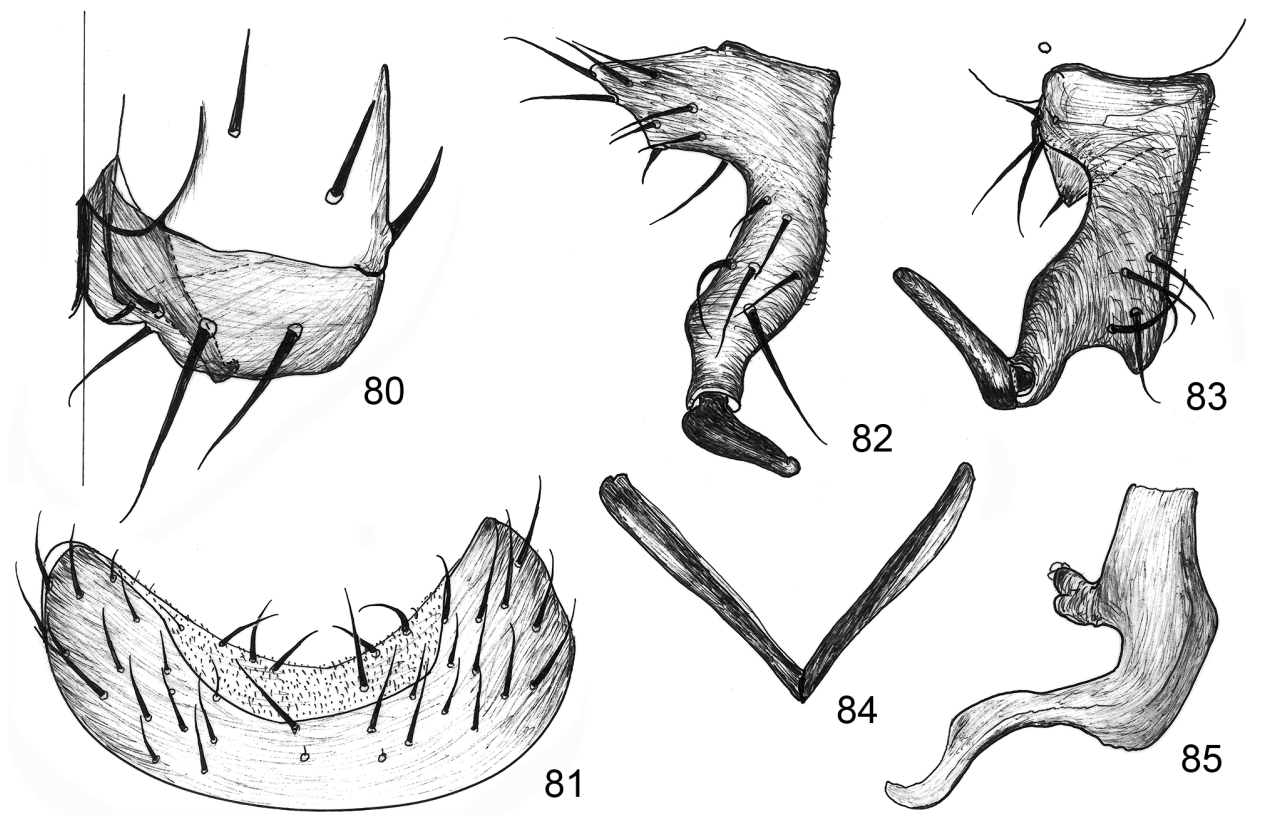


\section{Trachyopella (N.) leucoptera (Haliday, 1836)}

Duda (1925: 202) published a female from Abyssinia Kovács - Marako. 1912. III. - „Trachyopella leucoptera Hal. $^{\prime}$ det. Dr. O. Duda [Duda's handwriting]. The specimen is still present in the Diptera Collection of the HNHM. It has no head and as a female cannot be used at the time being for further identification. There is no question that it belongs to the species group of the three new species described here. Vanschuytbroeck's $(1950,1951)$ records from Zaire are erroneous (cf. RонÁčEK \& MARSHall 1986).

\section{Nudopella marshalli sp. n.}

(Figs 80-85)

Holotype (HNHM, abdomen with genitalia in a plastic microvial with glycerol): male, RSA: KwaZulu Natal, N Drakensberg, along eNdumeni River - on sedge and on mud, Jan 31, 2007, No. 45, leg. L. Papp.

Size (in mm): body length 1.28 , wing length 1.16 , wing width 0.54 .

Description. Male. Head. Face strongly concave, shiny. Eye bare. Cephalic setae not too long but thick. Two strong plus several short internal orbital setulae present, i.e. interorbitals as in N. operta. Two latero-clinate fronto-orbital setae. Parafacial row of setulae continued on gena below eye (5-6 thin hairs there). Longitudinal axis of eye $0.19 \mathrm{~mm}$. Postocellars extremely long and thick, intra-ocellars strong and divergent, more than half length of ocellar seta. Ocellar pair thick, strongly divergent; occi strongly reduced, occe long and thick. Four pairs of strong interfrontals. Gena below eye $0.10 \mathrm{~mm}$, genal seta 0.12 $\mathrm{mm}$ long. Vibrissa probably strong (broken off on the holotype). Antenna medial scape seta $0.07 \mathrm{~mm}$. Pedicel setae long, though not thick. First flagellomere with very long apical hairs of $0.03 \mathrm{~mm}$, with long hairs on entire surface, longest ones at apex. Aristal cilia very long, $0.03-0.035 \mathrm{~mm}$. Arista (slightly curved) at least $0.55 \mathrm{~mm}$ long. About 8 rows of acrotrichals on suture, one long posterior dorsocentral pair, apical scutellar seta $0.28 \mathrm{~mm}$; one long posterior katepisternal seta $0.14 \mathrm{~mm}$. Medial postpronotal seta much shorter than lateral pair. Wing membrane light brownish, veins light brown. Wing broad, nearly half of wing length. A single long costagial seta $0.125 \mathrm{~mm}$. Cs 1 setae in 2 rows; longest ones, $0.05 \mathrm{~mm}$. Second costal section incrassate, $0.025 \mathrm{~mm}$ broad, $0.39 \mathrm{~mm}$ long, third costal section, $0.32 \mathrm{~mm}$, costal ratio, 1.27. Costa beyond tip of $\mathrm{R}_{4+5}$ by $0.10 \mathrm{~mm}$. M-M crossvein, $0.09 \mathrm{~mm}, \mathrm{RM}-\mathrm{MM}$ section of $\mathrm{M}_{1+2}, 0.14 \mathrm{~mm}$, index 1.57. Halter light brown. Mid tibia with

Figs 73-85. Nudopella species. 73-79 $=$ N.erratica sp. $\mathrm{n} .:$ $73=$ mid basitarsus, ventral side, other setae omitted, $74=$ sternite 5 , ventral view, $75=$ right half of epandrium and subepandrial sclerite with right cercus, caudal view (some setae omitted), $76=$ synsternite, ventral view, 77 = postgonite, lateral view, $78=$ subepandrial sclerite, ventral view, $79=$ surstylus, lateral (i.e. largely the broadest). $80-85=$ Nudopella marshalli sp. n., holotype male, postabdomen and genitalia. $80=$ right ventral part of epandrium with cercus and subepandrial sclerite, caudal view, 81 = sternite 5 , ventral view, $82=$ surstylus, lateral view, $83=$ surstylus, caudal view, $84=$ subepandrial sclerite, ventral view, $85=$ postgonite, lateral view. Scale bar: $0.2 \mathrm{~mm}$ for Figs 74, 76, 81, $0.1 \mathrm{~mm}$ for Figs 73, 75, 77-80, 82-85 
strong mid ventral seta. Mid tibial armature: anterodorsals at 7.5/30 (short), 10.5/30 (long \& thick), 22/30 (weak), actually dorsal setae at 22/30 (weak), 24/30 (strong), posterodorsals at $7 / 30$ (weak), 22/30 (the longest tibial seta). Ventroapical seta extremely long, $0.07 \mathrm{~mm}$. Mid
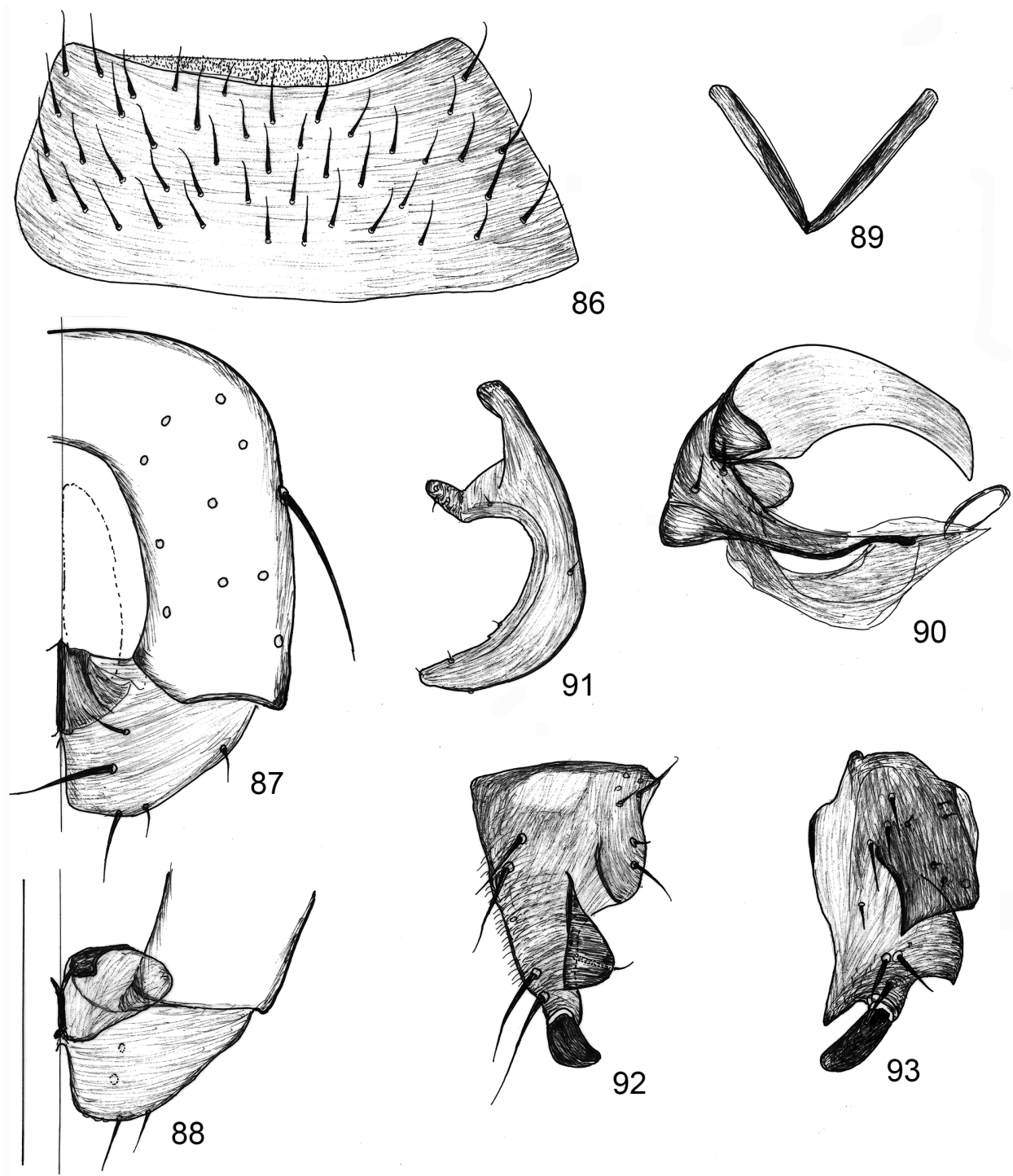

Figs 86-93. Nudopella pseudoperta sp. n., male postabdomen and genitalia. $85=$ sternite 5, ventral view, $86=$ synsternite, subventral view, $87=$ right half of epandrium and cercus, caudal view, 88 = left ventral part of epandrium and left cercus with subepandrial sclerite, anterior view, $89=$ subepandrial sclerite, ventral view, $90=$ synsternite, subventral view, 91 = postgonite, lateral view, 92 = surstylus, caudal view, $93=$ surstylus, lateral view. Scale bar: $0.2 \mathrm{~mm}$ for Figs 86, 90, $0.1 \mathrm{~mm}$ for Figs 87-89, 91-93 
basitarsus (cf. Fig. 73), $0.175 \mathrm{~mm}$ long, with paired setae ventrally. Hind tibia with a long dorsal preapical seta, as long as tibia diameter.

Tergites 4 and 5 with very long postero-caudal setae. Sternite 4 rather, wide, medial part with a deep broad concavity. Sternite 5 (Fig. 81) with long strong setae also on its medio-caudal membraneous part. Sternite 6 portion extremely short and broad: left side joins subdorsally to sternite 7 portion, right side ends under sternite 5 . Sternite 6 parallel to sternite 7 portion, sternite 6 medially turns to be perpendicular to abdominal axis, building anterior wall of genital pouch. Epandrium $0.09 \mathrm{~mm}$ long dorsally. Male cercus reduced, cercal part (Fig. 80) with very long setae. Subepandrial sclerite strictly V-shaped, rather thin in ventral view, with two lateral, ventrally directed arms, as seen in caudal view (Fig. 80). Hypandrium thin, very thin sagittally, without any trace of appendage. Phallapodeme slightly more curved than in N. operta. Distiphallus is rather similar to that of N. operta and N. erratica. Postgonite (Fig. 85 ) very characteristic: basal $1 / 2$ broader, in profile inner contour more curved than outer, apical half S-curved, apical part strongly narrowed but apex not sharp. Surstylus (Figs 82-83) large and long: broad-based, medial part narrow, ending in a triangular lateral process, apical part medio-clinate, L-shaped with extremely large black apical "spine".

Female unknown.

Etymology. This new species has been dedicated to Prof. Dr. Stephen A. Marshall (Guelph University, Canada) in recognition of his great contribution to the taxonomy of the Sphaeroceridae, including the species of the genus Trachyopella (Nudopella).

Comment. The other two species are very similar, and so only a few features other than those of the male genitalia are described. The male cercus in T. marshalli is reduced as in N. operta, while the setae in the cercal part are very long when compared to $N$. erratica.

\section{Nudopella pseudoperta sp. $\mathrm{n}$.}

(Figs 86-93)

Holotype (HNHM): male, RSA: 1 male: Eastern Cape Prov., Hogsback, Mistyfell House, No. 2, on compost, GPS02, S32 $34^{\prime} 41.0^{\prime \prime}$ E26 55' 23.9”', 1375 m, Jan 7, 2007, L. Papp \& M. Földvári.

Paratypes: 1 male (right wing separated, glued below the specimen, genitalia in a plastic microvial) (HNHM): RSA: Eastern Cape Prov., beside Bloukrans River, Jan 14, GPS17, S33 ${ }^{\circ} 57^{\prime} 20.9^{\prime \prime}$ E23 $38^{\prime} 18.8^{\prime \prime}, 28$ m, No. 24, L. Papp \& M. Földvári; 1 female (HNHM): KwaZulu Natal, S Drakensberg, nr Garden Castle, riverside meadow [Mlambonja River], Jan 22, No. 34, GPS21, S29 44' 59.4' E29 $12^{\prime}$ 42.1'”, 1811 m; 1 male, 1 female (HNHM): ibid., Garden Castle, along Mlambonja River, No. 33. 2 males, 4 females (BMSA): 1 male: Malaise traps dense Leucosedea dominated scrub - RSA: Free State, Harrismith, Scotland farm at:

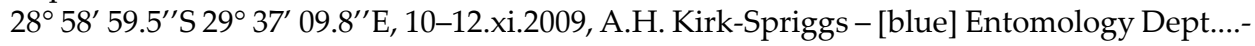
BMSA(D) 12925; 1 male, 3 females (BMSA): ibid., KZN, Royal Natal N.P., Thendele, 1600m, $28^{\circ} 42.378^{\prime} \mathrm{S} 28^{\circ} 56.083^{\prime} \mathrm{E}, 15-17 . i i .2010$ - [blue] Entomology Dept....- BMSA(D) 21524 (ठ), 21536, 20511, 21521; 1 female (BMSA): Malaise trap, Oubrug, Storms Rivier margin, indigenous forest - RSA: Tsitsikamma N.P., Plaatbos Nat. Reserve at: $33^{\circ} 59.283^{\prime} \mathrm{S} 23^{\circ} 55.275^{\prime} \mathrm{E}$, 20-22.i.2009 - [blue] Entomology Dept....- BMSA(D) 03756. 
Size (in mm): body length 1.59 (holotype), 1.36-1.76 (paratypes), wing length 1.54 (holotype), $1.54-1.82$ (paratypes), wing width 0.66 (holotype), $0.65-0.73$ (paratypes).

Description. Genal seta not longer than first peristomal. Wing. Longest seta on first costal section $0.11-0.12 \mathrm{~mm}$. $\mathrm{r}_{1}$ cell shaded, definitely brownish. Cs2 $0.55 \mathrm{~mm}$, Cs3 $0.35 \mathrm{~mm}$, costal ratio 1.56. Costal vein extending tip of $R_{4+5}$ by $0.13 \mathrm{~mm}$. RM-MM section of vein $\mathrm{M}_{1+2}$ $0.18 \mathrm{~mm}$, cross-vein M-M $0.11 \mathrm{~mm} . \mathrm{M}_{3+4}$ with a long appendage vein to discal cell $0.12 \mathrm{~mm}$. Hind tibia with a dorsal preapical seta longer than tibial diameter at its origin.

Male sternite 5 (Fig. 86) simple, caudal membranous part very short and bare. Male synsternite (Fig. 90) slightly different in structure from that of $N$. erratica, as the laterally longer sternite 6. Male genitalia (Figs 87-93) with large, broadly rounded cercus (Fig. 87), sagittal connection very short; cercus with some setae. Subepandrial sclerite (Figs 87, 89) more rounded and short. Surstylus (Figs 92-93) short, its lobes with a large round caudal lobe and its subapical lobe close to apical thorn. Postgonite (Fig. 91) strongly curved, apex not sharp.

Etymology. The specific epithet of this new species is ' $p$ seudoperta' as a combination of the Greek words 'pseudes' [= false] and the specific epithet of operta, a species described by RoháčEK and MARSHall (1986) from Korea.

Comments. RoháčEK and Marshall's (1986) description of T. (N.) operta is very accurate, what helps further studies in the genus. PAPP (2008b) identified his Nudopella specimens from South Africa incorrectly, using low magnification. A careful study of those specimens revealed three different species from Nudopella on material collected on dung of big hoofers in South Africa. These species occur together with N. erratica (see No. 33 of the RSA materials above). This, of course, is challenging for proper discrimination of the species, but reinforces the concept that they are separate species. The male sternite 5 in $N$. pseudoperta, sp. $\mathrm{n}$. is somewhat larger than in its congeners. The male synsternite is structurally similar to that of $N$. erratica, differing only in details, e.g., sternite 6 portion is longer laterally. The surstylus in N. pseudoperta, sp. n. is shorter than in N. marshalli and about as long as that of $N$. erratica, but the lobes are different.

\section{Paraminilimosina similis sp. $\mathrm{n}$.}

(Figs 94-99)

Holotype (HNHM): male, TANZANIA: Morogoro region, Mikumi National Park, Mikumi Tented Camp - Netting over excrement of elephant, Feb 1, 1987, leg. S. Mahunka - T. Pócs - A. Zicsi, No. 8.

Paratypes (HNHM): 1 male (abdomen with genitalia in a plastic microvial with glycerol) 4 females: same labels as for the holotype; 1 male: Nigeria [Bauchi State]: Yankari (on label incorrectly Yangui) Reserve, Wikki - Aug. 15, 1978, leg. A. Demeter, No. 22 [buffalo dung from previous night].

Size (in mm): body length 1.15 (holotype), 1.15-1.45 (paratypes); wing length 1.19 (holotype), 1.18-1.38 (paratypes); wing width 0.51 (holotype), $0.51-0.56$ (paratypes). 
Description. Male. Head, scutum, scutellum, abdomen and legs light brown. A large triangular protuberance present between antennal bases, facial plate strongly concave in profile; mouth edge strongly upturned, mouth cavity extremely large. Anterior half of frons, scape and pedicel dirty yellow or ochre. Two fronto-orbitals, ocellar, outer and inner vertical pairs strong, outer and inner occipitals similar, postocellar pair nearly parallel, comparatively long $(0.06 \mathrm{~mm})$; four to five short interfrontal pairs. Genal seta distinct (somewhat longer than $0.04 \mathrm{~mm}$ ), but peristomal and posterior genal setae longer, $0.05-$ $0.06 \mathrm{~mm}$. Vibrissa $0.16 \mathrm{~mm}$, longitudinal axis of eye $0.25 \mathrm{~mm}$, genal width below eye 0.06 $\mathrm{mm}$. Antennal scape much broader than long, with a $0.04 \mathrm{~mm}$ long medial seta; pedicel setae very long, e.g., dorsal seta $0.08-0.085 \mathrm{~mm}$. First flagellomere slightly conical, arista 0.095-0.105 mm long. Only one posterior pair of dorsocentrals. Prescutellar acrostichal distinct, $0.10-0.11 \mathrm{~mm}$; thoracic setae sparse, but long setulae, including acrostichals; one postpronotal, 2 notopleurals (posterior pair on a callus, maybe named as presutural), 1 large supra-alar and post-alar (posterior) separable, other not longer than setulae. In females a lateral presutural also developed. One rather long katepisternal seta. Sub-basal seta of costa short, $0.10 \mathrm{~mm}$. Inter-crossvein section of $\mathrm{M}_{1+2}, 0.15 \mathrm{~mm}, \mathrm{M}-\mathrm{M}$ cross vein 0.08 $\mathrm{mm}$. Second / third costal sections $0.29 / 0.40 \mathrm{~mm}$, ratio $0.72 . \mathrm{R}_{4+5}$ slightly upcurved, C distinctly extending beyond tip of $\mathrm{R}_{4+5} . \mathrm{M}_{3+4}$ continued on a section of $0.15 \mathrm{~mm}$ distally to MM. Alula narrow, elongated. Mid tibia with a normal ventro-apical seta; antero-dorsals at basal third and 11/15, a more dorsal (dorsal) at 13/15, no mid ventral seta. Anterior preapical seta distinct. Otherwise no peculiarities on legs.

Abdominal sternites 2-3 (Figs 93-94) with peculiar modifications: in lateral view, it forms a large round knob-like process with a smaller swelling basally; in ventral view, more intricate. Sternite 5 (Fig. 95) almost as long as wide, its medio-caudal part (Fig. 96)

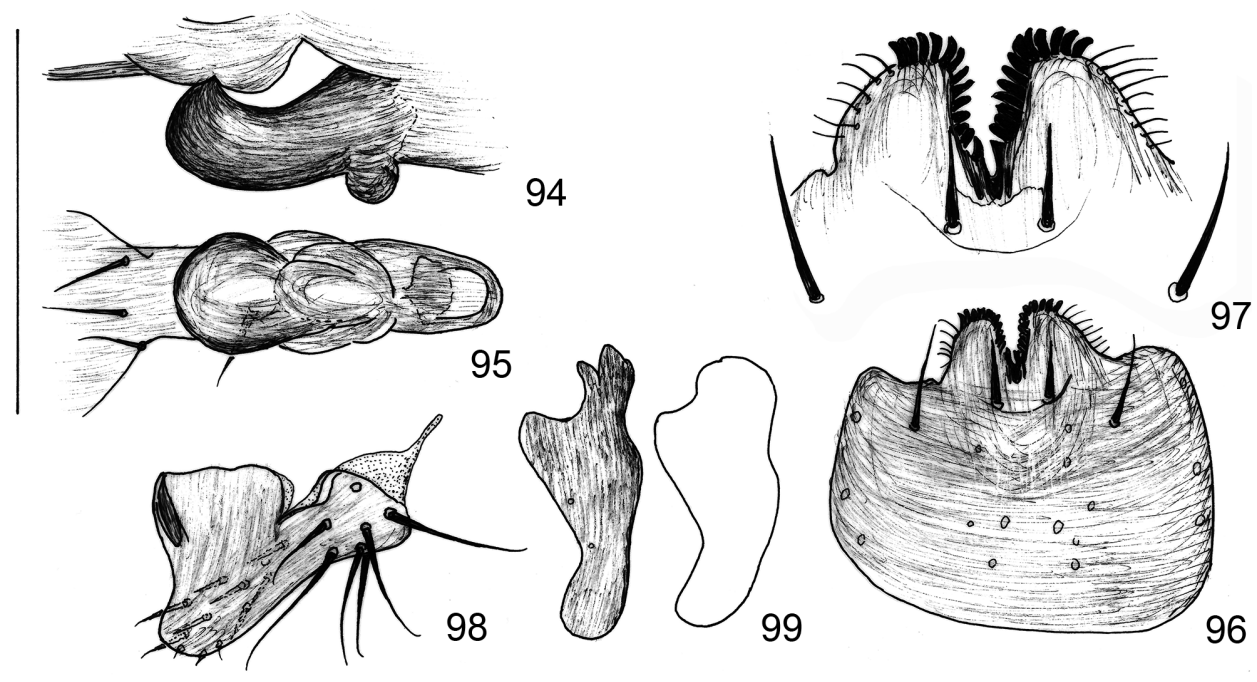

Figs 94-99. Paraminilimosina similis sp. n., male postabdomen and genitalia. $94=$ preabdominal structures, lateral view, $95=$ same, ventral view, $96=$ sternite 5 , ventral view, $97=$ caudal part of sternite 5 in higher magnification, ventral view, $98=$ surstylus, in broadest (sublateral) view, 99 = postgonite, lateral view (contours: at broadest). Scale bar: $0.2 \mathrm{~mm}$ for Figs 94-96, $0.1 \mathrm{~mm}$ for Figs 97-99 
composed of a pair of blunt lobes, with numerous blunt black pegs. Surstylus (Fig. 97) much longer than high basal part with long setae, apical part bears setae mostly on mesial surface, setae covered when in lateral view. Postgonite (Fig. 98) rather simple, bare, its broadest extension in sublateral view.

Female: unknown.

Etymology. The specific epithet (Latin: 'similis' = like, resembling) refers to the characteristics of this new species resembling to the formerly described Oriental species in the genus.

Comments. $P$. similis sp. $\mathrm{n}$. is particularly similar to $P$. miraculisterna L. Papp, 2008 (Thailand). The black pegs medio-caudally on sternite 5 is smaller and more numerous in the new species. The surstylus is very different, with largely different modifications of the pregenital sternites (cf. PAPP 2008a: figs 16 misnumbered as fig. 15 and 17). The body colour is similar to that of P. miraculisterna. The ratio between second and third costal sections is 0.72 , larger than in the Oriental species of the genus. The abdominal sternites 2-3 in $P$. similis, sp. n. are intricate, but it is even more complex in P. miraculisterna (see PAPp 2008a: fig. 17).

PAPP (2008a: 57) referred to the specimens described here as an Afrotropical species other than the two Oriental species described there and an additional new species from India.

\section{Parapoecilosomella formosa sp. n.}

(Figs 100-107)

Holotype (IRSNB): male, Malaise traps lowland evergreen primary forest (disturbed) - D.R. CONGO: Oriental prov., Likombo forest, 2 km SW Bomane, 1.28349, 23.72358, 20-22, v. 2010, A.H. Kirk-Spriggs - [yellow] Boyekoli Ebale Congo Expedition 2010 - BECE00609.

Paratypes: 1 male (BMSA, gen. prep.): ibid., BECE00605; 1 male (HNHM, abdomen with genitalia in a plastic microvial with glycerol): ibid., BECE00816; 2 females (BMSA): ibid., BECE 00819, BECE00613.

Size (in mm): body length 2.47 (holotype), 2.31-2.49 (paratypes); wing length 2.75 (holotype), 2.36-2.77 (paratypes); wing width 1.17 (holotype), 1.04-1.18 (paratypes).

Description. Male. Body not particularly strongly sclerotized or granulose. Head, antenna and armature of legs similar to that of $P$. lusingana (Vanshuytbroeck). One long latero-clinate upper orbital seta, 3 pairs of interfrontals present, some minute additional lateroclinate setulae close to orbitals. occe, occi weak, postocellar seta not discernible. Facial plate not protruding, centrally with a low carina. Occipital setae weak. Genal seta long, 0.15 to $0.20 \mathrm{~mm}$. Prosternum linear. One very strong posterior and one weak anterior pair of $d c$ setae, no prsc. No setulae between apical scutellar setae; disc of scutellum bare. Acrostichals in 8-10 irregular rows. Two pairs of strong katepisternal setae present. Pulvilli and claws weakly developed; ventroapical spur of hind tibia largely reduced. Mid tibia without ventral preapical seta. Male mid tibia ventrally without a ventroapical seta but with nu- 
merous very long ( $0.4 \mathrm{~mm}$ or even longer) white hairs; female mid tibia with the normal $0.15 \mathrm{~mm}$ long ventroapical seta. No long ventral seta on mid basitarsus. Not 1 but 2 ventroapical setae on hind tibia, but they are short $(0.06-0.07 \mathrm{~mm})$. Wing pattern complex. Costa ending at apex of $R_{4+5}$, with longer setae along entire length. Costal setae long from base to apex of $R_{1}$. $R_{2+3}$ usually less strongly bent, $R_{2+3}$ without a vein appendage. CuA usually not developed. $R_{2+3}$ not bisinuate or much less so. $R_{2+3}$ oblique, almost straight, distal end perpendicular to costa (PAPP 2008a: fig. 313). Second costal section slightly longer. Abdomen well sclerotised. Tergite 1 pigmented and sclerotised only laterally, medial part sclerotised on two lateral though confluent parts. Tergite 2 desclerotised antero-medially on a small triangular area. Sternite 5 wide and short, only $0.10 \mathrm{~mm}$ long, with some seven long setae at distal third. Sternites 2 to 4 peculiar, only partially with marble irregular spots. Sternite 5 (Fig. 100) with long setae, mainly subcaudally. Caudal margin of sternite 5 (Fig. 101) with short, but not thin sharp setae. Synsternite (Fig. 103) with sternite 6 portion with more concave right membranous area (Fig. 103), medial part of sternite 7 darker. Caudal edge

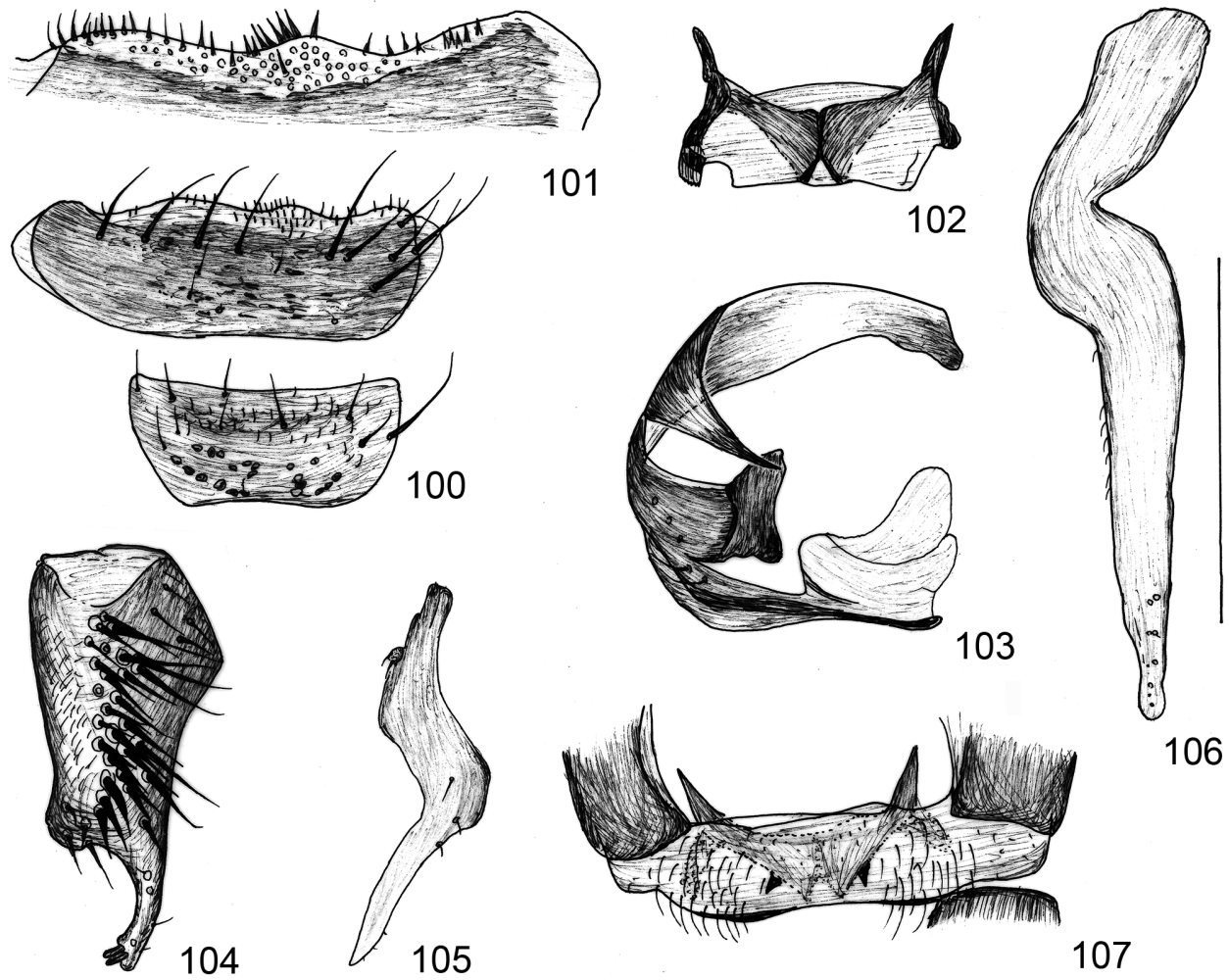

Figs 100-107. Parapoecilosomella formosa sp. n., male postabdomen and genitalia. $100=$ sternites 4 and 5, ventral view, $101=$ caudal part of sternite 5 in higher magnification, ventral view, 102 = subepandrial sclerite, anterior (!) view, $103=$ synsternite, ventral view, $104=$ surstylus, broadest (sublateral) view, $105=$ postgonite, lateral view, $106=$ postgonite, caudal view, 107 = cercal part of epandrium with contours of subepandrial sclerite and base of surstylus, caudal view. Scale bar: $0.4 \mathrm{~mm}$ for Fig. 100, 103, $0.2 \mathrm{~mm}$ for Figs 101-102, 104-105, 107, $0.1 \mathrm{~mm}$ for Fig. 106 
of sternite 8 portion desclerotised and demelanised on a section of $0.04 \mathrm{~mm}$. Epandrium only $0.10 \mathrm{~mm}$ long dorsally and sagittally. Subepandrial sclerite (Fig. 102) more than twice wider than long. Anal lamellae weakly membranous, with dorso-lateral extension. Ventral part demelanised desclerotised, including cercal part of epandrium (Fig. 107), covered by short dense setae. Surstylus (Fig. 104) with ventral process longer, with a more slender base. Body of surstylus with more lateral setae (cf. PApp 2008a: figs 108, 110), with numerous thick spiniform setae. Hypandrium similar to that of $P$. lusingana. The apical threadlike process of distiphallus is very short. Postgonite with numerous setae (Papp 2008a: figs $105,107)$, apical half very thin, apical half straight in anterior/caudal view, but strongly sigmoid in basal half.

Female: As males, except for postabdomen.

Etymology. The specific epithet (Latin: 'formosus' = beautiful) refers to the spectacular body and wings of the new species.

Comments. Wing pattern usually more complex than in most species of Poecilosomella (PApp 2008a: figs 310, 312-316). Male sternite 5 medio-caudal setose area somewhat broader than in P. lusingana. Sternites 2 to 4 marble spot pattern distinct from P. lusingana (Fig. 100, cf. PApr 2008a: fig. 103). Synsternite (Fig. 103) in P. formosa with medial part of sternite 7 portion darker, markedly different from that of P. lusingana. Cercal process smaller and more dorsal than in P. lusingana. Apical part of distiphallus differs on both of these species.

\section{Philocoprella africana sp. n.}

$$
\text { (Figs 108-118) }
$$

Holotype (HNHM): male, R.S.A.: Eastern Cape Prov., Shamwari Game Reserve, on elephant dung, Jan 11, GPS10, S33 ${ }^{\circ} 4^{\prime} 47.0^{\prime \prime}$ E26 $6^{\circ} 05^{\prime} 45.0^{\prime \prime}, 301$ m, No. 14, leg. L. Papp \& M. Földvári.

Paratypes: 74 males 66 females (HNHM) 1 male, 1 female (BMSA), 1 male, 1 female (NMSA), same data as holotype.

Size (in mm): body length 1.00 (holotype), 0.95-1.15 (paratypes); wing length 0.95 (holotype), 0.875-0.98 (paratypes), wing width 0.425 (holotype), $0.40-0.45$ (paratypes).

Description. Head. Four pairs of medium-long interfrontals, two pairs of lateroclinate fronto-orbitals, plus five or more short thin fronto-orbital pairs, two pairs of short latero-clinate inter-ocellars, and one inclinate pair of postocellars. Parafacialia with minute white hairs. Width of gena $0.05 \mathrm{~mm}$, longitudinal axis of eye $0.225 \mathrm{~mm}$. Genal seta 0.07 $\mathrm{mm}$ (holotype and a paratype female), i.e. slightly longer than first peristomal seta. Ocellar triangle reaches middle of frons. First flagellomere round, with long $(0.015 \mathrm{~mm})$ dense apical hairs. Arista $0.36 \mathrm{~mm}$ long, with short $(0.012 \mathrm{~mm})$ cilia. Postpronotum with 3 pairs of setae: one lower medio-clinate short seta, one rather large reclinate medial seta and one pair of medio-clinate medial setae; one pair of posterior $d c$, scutellar setae (PAPP 1973b: fig. 151). Acrostichal setulae well ordered, eight rows on suture. Presutural seta $0.09(0.085) \mathrm{mm}$ long, two pairs of kepst, anterior pair less than half of posterior pair. Other head and thoracic setae as in Ph. italica. Wing very light brown, veins light brown. Costal vein both hori- 
zontally and dorsally with (5) 6-7 long setae of $0.06 \mathrm{~mm}$, costagial setae not much longer $(0.07 \mathrm{~mm})$. Second costal section $0.21 \mathrm{~mm}$, third section $0.205 \mathrm{~mm}$, ratio 1.03 . Costal vein extending beyond tip of $\mathrm{R}_{4+5}$ by $0.175-0.185 \mathrm{~mm}$. Inter-crossvein section (RM-MM) of $\mathrm{M}_{1+2 \text {, }}$ $0.08 \mathrm{~mm}, \mathrm{M}-\mathrm{M}$ cross-vein $0.075 \mathrm{~mm}$. Costal seta up to $0.05 \mathrm{~mm}$. Discal cell edged, visible appendages of $0.05 \mathrm{~mm}$. Alula narrow, $0.05 \mathrm{~mm}$ broad. Mid tibial armature: anterodorsals at 6/26 (medium), 13/26 (medium), 18/26 (long), posterodorsals at 9/26, 18/16 (long). No ventro-apical seta on mid tibia. A rather strong mid ventral seta at 15/26 and a short subapical ventral seta. Hind tibia with a long dorsal preapical seta of $0.05-0.055 \mathrm{~mm}$ plus other (3-4 pairs) more dorsal long hair-like setae. Both antero- and postero-apical setae of mid tibia medium-long $(0.04 \mathrm{~mm})$, i.e., definitely shorter than ventral basitarsal seta $(0.06 \mathrm{~mm}$ in male, $0.07 \mathrm{~mm}$ in female). Tergite 5 much broader, but not much longer than sternite 5; sternite 5 subquadrate (Fig. 108), with some scattered long setae, a very small sub-triangular medio-caudal part with fine hairs in ca. 6 rows (Fig. 109). Synsternite peculiar: sternite 8 occupies its entire dorsal part, while sternite 6 part normal, sternite 7 part and ventral part of sternite 8 very small (Fig. 110). Epandrium short (Figs 111, 115), epandrial complex closed ventrally, cerci only slightly less sclerotised. Subepandrial sclerite (Fig. 112) large, much broader than long, a darker and more sclerotised sagittal part and extended latero-ventral edges. Hypandrium (Fig. 115) peculiar, lateral parts strongly and broadly fused to epandrium, medial part ("rod") long and broad, basally Y-shaped, proximal end connected to lateral parts, distal part moderately extended horizontally. Surstylus (Figs 113-114) short, not much higher than long, with numerous long setae, but no thicker thorns. Basiphallus elongated ventrally, but without epiphallus (Fig. 117), distiphallus compact. Phallapodeme (Figs 116-117) long, proximal end joining basiphallus broadly extended, distal third formed by a broad horizontal plate. Postgonite (Fig. 118) characteristic, with a broad base, apical part in lateral view geniculate, apical third slender, with blunt apex.

Female: cercus with 2 long sinuous hairs.

Etymology. The specific epithet refers to its distribution in the Afrotropical region.

Comments. This is the first description of the genitalia of a species in the genus Philocoprella Richards. The scutellar setae in P. africana are similar to that of Rachispoda.

It is out of the scope of this paper to revise Philocoprella. In the collection at the HNHM there are two additional undescribed Oriental species of the genus, as well as congeneric specimens from Nigeria and Kenya that have not been identified to species level. The minute size of the species makes difficult the study of the morphology. An additional problem is that the type species of the genus, Ph. arvernica (Richards, 1929), is known only from the holotype, deposited at the London NHM (RонÁček et al. 2001). As far as I know, it has not been studied after the original description. It has only one pair of short setae on scutellum disc, which is quite unique. I have seen several thousand Philocoprella specimens (we captured more than 1000 specimens during our 2002-2005 project on the Hortobágy; PAPP 2007), but I have not seen any specimen with only one pair of setae on the disc of scutellum. The diagnostic features of the new species are summarised in the key below. 
Key to the known species of Philocoprella Richards, 1929

(Ph. arvernica (Richards) is not considered)

1. $R_{4+5}$ straight. $C$ extending tip of $R_{4+5}$ by a much longer section than mid basitarsus

- $\quad \mathrm{R}_{4+5}$ strongly upcurved (PAPp 1973b: fig. 23F). C almost reaching wing apex. $C$ extending tip of $R_{4+5}$ length of mid basitarsus

2. Five pairs of interfrontal setae. RM-MM to $M-M$ section of $M_{1+2} 1.5-2.0$ times longer than cross-vein M-M. Female cercus with two very long, sinuous hairs. Mongolia. $\quad$ Ph. mongolica L. Papp, 1973

- $\quad$ Four pairs of interfrontal setae. RM-MM to M-M section of $\mathrm{M}_{1+2}$ hardly longer than cross-vein M-M. Dorsal hair of female cercus considerably shorter then apical hair

Ph. rectiradiata L. Papp, $1973^{*}$

3. Male mid basitarsus with long ventral sub-apical seta and female cercus with two long sinuous hairs. Male genitalia (Figs 108-118). Afrotropical

Ph. africana sp. n.

- Male mid basitarsus without long sub-basal seta or female cercus with short hairs only. Palaearctic

4. Male mid basitarsus without long sub-basal ventral seta; female cercus with 2 long sinuous hairs

Ph. quadrispina (Laurence)

- Male mid basitarsus with long sub-basal ventral seta; female cercus with short hairs only

Ph. italica (Deeming)

Figs 108-118. Philocoprella africana sp. n., male postabdomen and genitalia. $108=$ sternite 5 with contours of tergite 5 , ventral view; $109=$ medio-caudal part of sternite 5 in higher magnification; 110 = synsternite, ventral view; 111 = epandrium with cerci and subepandrial sclerite, caudal view; $112=$ subepandrial sclerite, broadest extension, i.e. subcaudal view; 113 = surstylus, caudal view; 114 = surstylus, in broadest extension, i.e. a subventralsubcaudal view; 115 = hypandrium and epandrium, ventral view; 116 = phallapodeme, dorsal view $117=$ phallus and phallapodeme, lateral view; $118=$ postgonite, lateral view (BPh: basiphallus). Scale bars: $0.2 \mathrm{~mm}$ for Figs 108, 110-111, 115, $0.1 \mathrm{~mm}$ for Figs 109, 112$114,116-118$

* I have to note here that the holotype of Ph. rectiradiata is mysteriously missing from the HNHM collection. The 2 male and 3 female paratypes are there; the holotype was not found even in loan lists, etc. In the frame of the revision of Philocoprella one must return to this problem. 

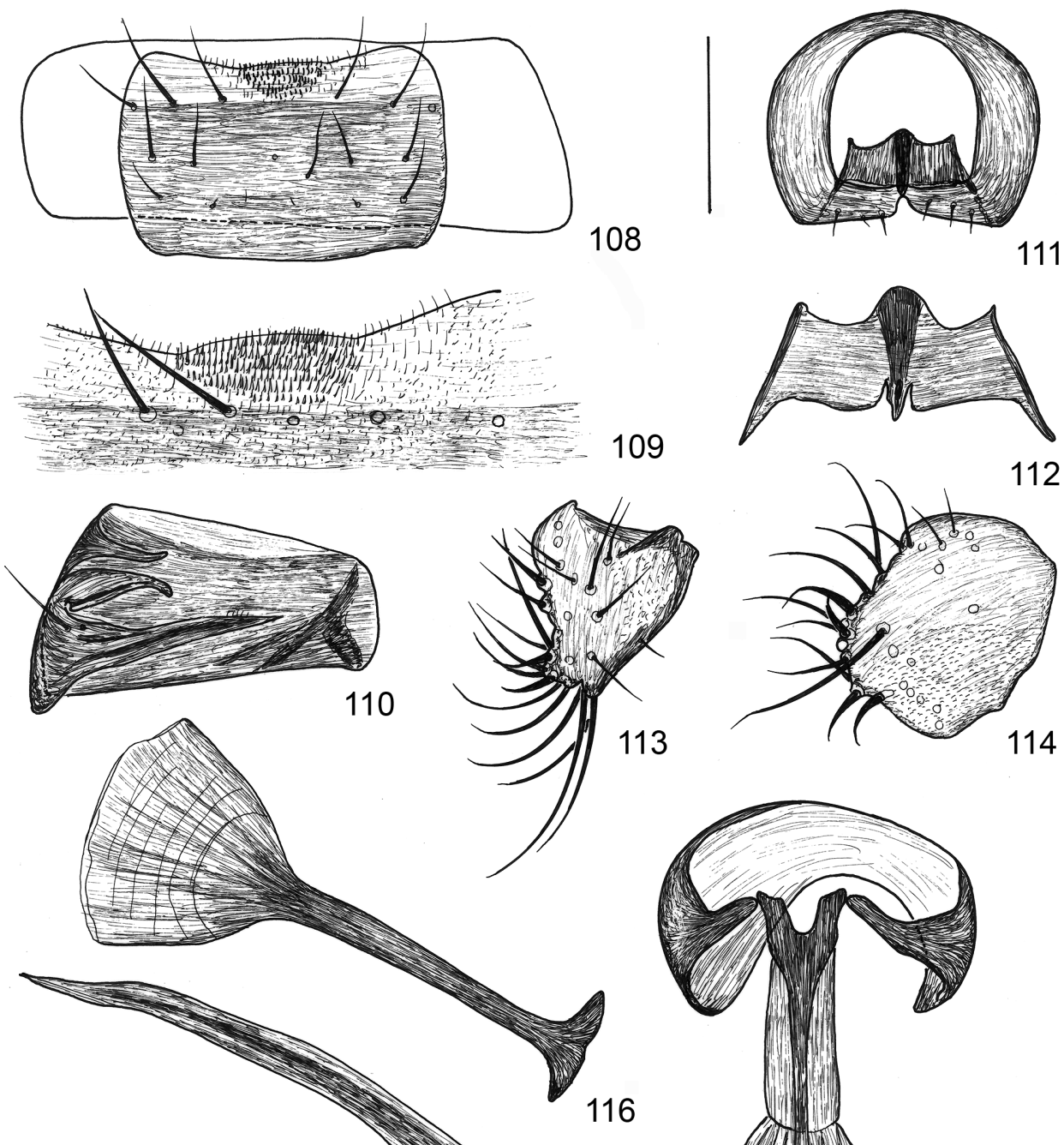

113

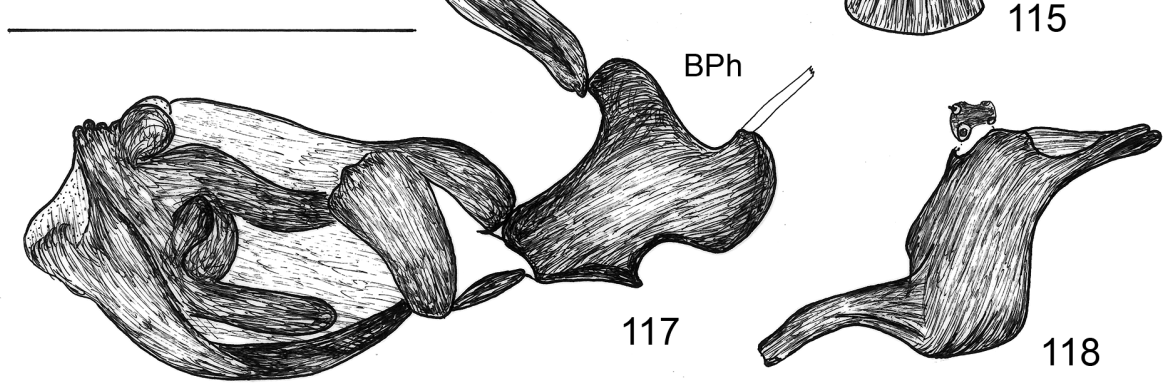




\section{Phthitia incognata sp. n.}

(Figs 119-133)

Holotype (HNHM): male, RSA: KwaZulu Natal, N Drakensberg, Rainbow Gorge, Jan 26-28, 2007, No. 39 - GPS29, S28 57' 36.7'” E29 13' 33.6”', 1529 m, L. Papp \& M. Földvári.

Paratypes (all males but one in HNHM, one male in BMSA): 10 males, 6 females, ibid., along Rainbow Gorge streamlet, yellow pans - Jan 28-31, 2007, No. 41, GPS31, S28 57' 43.2"' E29 13' 18.4"', 1516 m, leg. M. Földvári.

Size (in mm): body length 3.25 (holotype), 3.15-3.45 (paratypes); wing length 3.01 (holotype), 2.95-3.19 (paratypes); wing width 1.21 (holotype), 1.17-1.25 (paratypes).

Description. Male. Most features fit to those of the nominate subgenus. Facial plate short, mouth edge strongly produced, a large sub-triangular protuberance present between scapes. Pedicel longer than first flagellomere. Flagellomere 1 higher than long, with a narrowly rounded dorsal end. Pedicel with a wreath of long subapical setae. First flagellomere with ca. $0.025 \mathrm{~mm}$ long cilia. Arista $0.90-0.95 \mathrm{~mm}$ long. Palp with two long subapical plus several shorter ventral setae, 4 pairs of interfrontal setae, anterior one short; two lateroclinate fronto-orbital pairs, plus several short fronto-orbital setulae discernible. Postocellar seta indistinct, ocellar, outer and inner vertical, outer and inner occipital pairs long, thick. Longitudinal axis of eye $0.50-0.52 \mathrm{~mm}$. Parafacialia with short black setulae more ventrally, below eye longer and lighter setulae discernible. Vibrissa, $0.34 \mathrm{~mm}$, genal width (holotype) $0.17 \mathrm{~mm}$, genal seta $0.24-0.25 \mathrm{~mm}$ long. One long postpronotal seta, medial pair not discernible; two pairs of notopleurals (posterior pair on a large protuberance), presutural seta not long, 2 setae in intra-alar row : one supra-alar and one postalar one. Postalar seta in the supra-alar row very long, $0.65-0.69 \mathrm{~mm}$, anterior pair also long $(0.29 \mathrm{~mm})$. Two pairs of long dorsocentrals, between them 1, anteriorly 2 additional setae are longer than adjacent setae. No prescutellar seta. Apical scutellar seta extremely long, 1.00-1.05 mm. One long katepisternal $0.29 \mathrm{~mm}$, anterior pair not developed; some specimens with 1 or 2 short setae between apical and lateral scutellar setae. Wing membrane light brownish, veins ochre. Two costagial setae $0.16 \mathrm{~mm}$, i.e., not particularly long. Sections Cs2 $1.06 \mathrm{~mm}$, Cs3 0.85 $\mathrm{mm}$, ratio 1.25. RM-MM section $0.39 \mathrm{~mm}, \mathrm{M}-\mathrm{M}$ cross-vein $0.13 \mathrm{~mm} . \mathrm{M}_{1+2}$ definitely reaching wing margin though faintly. Anal vein broadly sigmoid, not reaching wing margin. Alula rather broad, liguliform, $0.12-0.13 \mathrm{~mm}$ broad. Halter knob light brown, stalk wax-yellow. Fore leg with no distinctive changes. Mid femur with two rows of antero-ventral and postero-ventral short black setae. Male mid tibia without mid ventral or ventro-apical seta; a complete row of short black, spiniform setae ventrally. Antero-dorsal setae at 15/68, 24/68, 39/68 (shorter), 48/68, 53/68 (more dorsal), 61-68 (shorter), postero-dorsals at 16/68 (thinner and shorter), 28/68, 52/68 (very long and thick), 61/68 (weak). A very thick anterior apical seta present. Hind tibia with a $0.15-0.16 \mathrm{~mm}$ long, thick black, slightly laterally curved, ventral spur. Both preabdominal tergites and sternites large, almost meeting laterally. Sternite 5 large (Fig. 119), U-shaped in anterior view, less sclerotised medio-caudally without a process, but with long thin setae on larger dark sockets. Sternite $6+7$ portion of synsternite (Figs 121-122) fused only dorsally, sternite 8 portion not fused with synsternite. Shape of sternite 6 complex ventrally (Figs 121-122), a thorn at left side and a sub-trapezoid medial black sclerite most ventrally; slightly dorsally a cup-like sclerite with a pair of lateral asymmetrical processes and a rightwards larger sclerite. Sternite 7 part simple, sternite 8 portion strongly convex, nearly $0.4 \mathrm{~mm}$ long dorsally. Epandrium with numerous lateral setae (Fig. 123). Subepandrial sclerite (Fig. 123, covered) small, only a transverse lath be- 
low anal opening. Pseudocerci enormously large, with numerous apical setae and a single thick spine. Hypandrium (Fig. 120) absolutely asymmetrical without rod (medial appendage). Subepandrial sclerite very short, transverse, connecting long dorsal appendages of

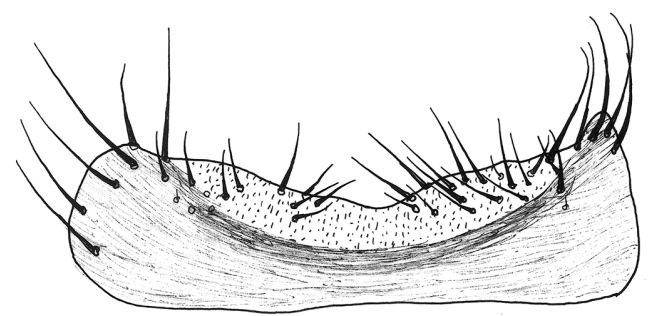

119
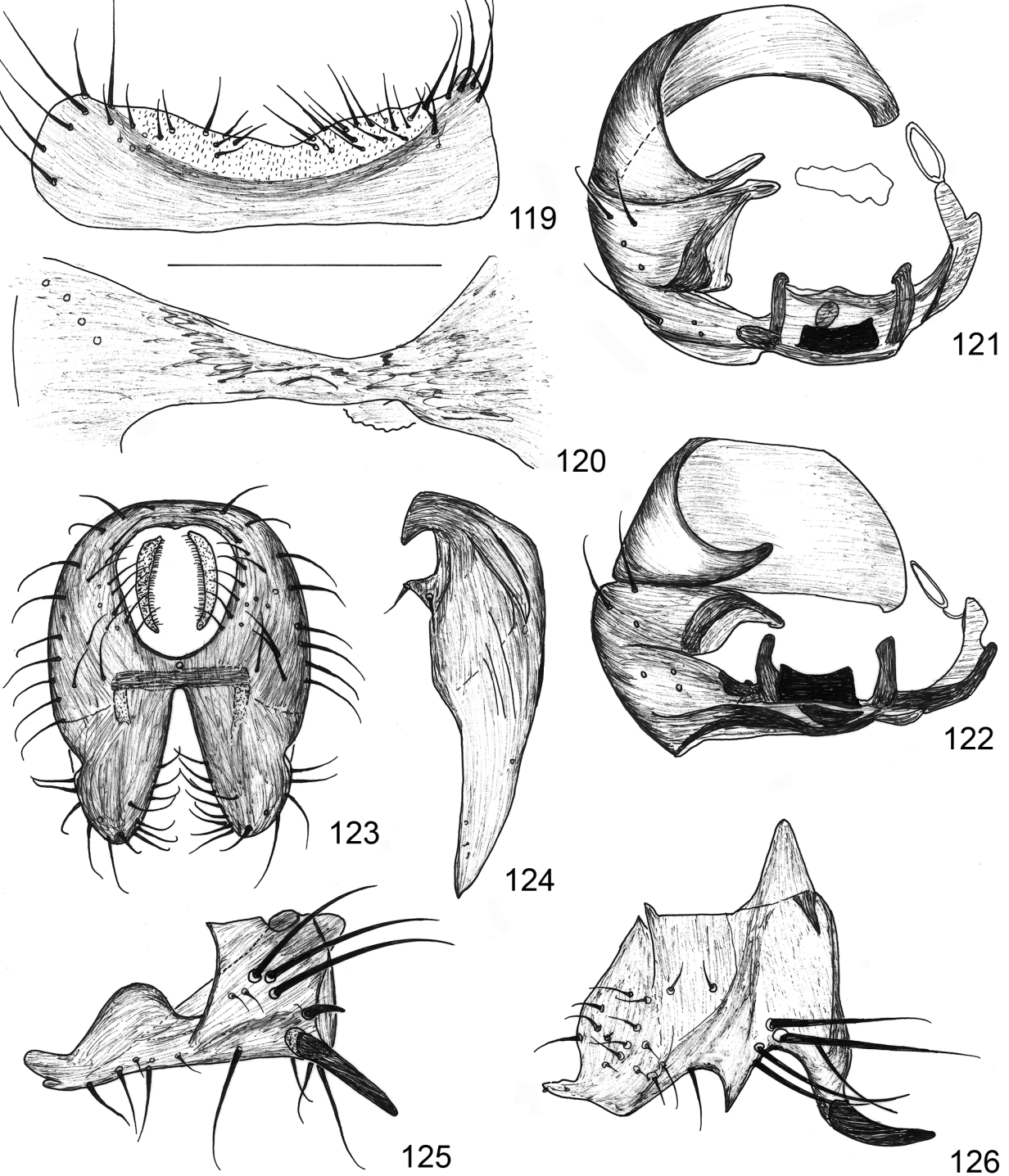

Figs 119-126. Phthitia incognita sp. n., male postabdomen and genitalia. $119=$ sternite 5, ventral view, 120 = hypandrium, ventral view, 121 = synsternite caudally, 122 = synsternite ventrally, 123 = epandrium and cerci, caudal view, 124 = postgonite, in lateral view, 125 = surstylus, lateral view, $126=$ surstylus, ventral view. Scale bar: $0.4 \mathrm{~mm}$ for Figs 119, 121-123, $0.2 \mathrm{~mm}$ for Figs 120 and for 124-126 
surstyli. Surstylus (Figs 125-126) with a recurved long and blunt caudal lobe, with a broad anterior lobe bearing an apical tooth; body of surstylus broadened horizontally (visible only in ventral view). Basiphallus (Fig. 129) high and short, phallapodeme comparatively small. Distiphallus (Figs 127-128) in three parts: basal part a small pentagonal plate in horizontal position, an apical part with a bifid black sclerite and a pair of very large auriform, 2-layered sub-basal lobes sideward. Postgonite (Fig. 124) connected to phallus by a narrow black lath, basal part broad, apical part narrowed, bifid apically.

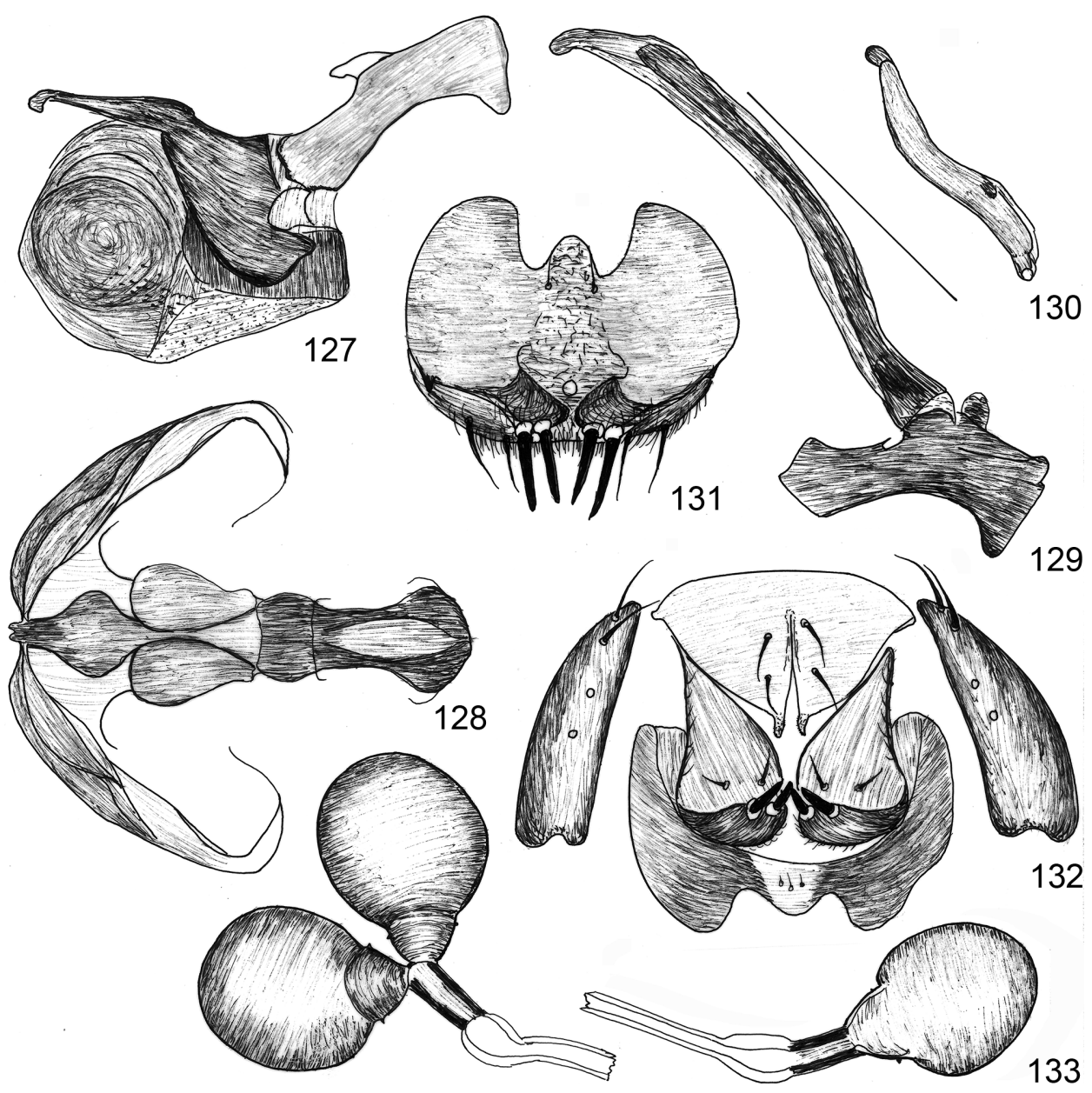

Figs 127-133. Phthitia incognita sp. n., male and female genitalia. $127=$ distiphallus, lateral view, 128 = same, ventral view, 129 = basiphallus and phallapodeme, lateral view, $130=$ ejaculatory apodeme, 131 = female hypoproct and cerci, broadest (subcaudal-subventral) view, 132 = female postabdomen, subdorsal view, 133 = spermathecae. Scale bar: $0.2 \mathrm{~mm}$ for Figs 127-129, 131-132, $0.1 \mathrm{~mm}$ for Figs 130, 133 
Female. Female mid tibia with a very long and thick ventro-apical seta but mid ventral seta lacking. Hind tibia also with thick black, slightly laterally curved, ventral spur. Postabdomen structurally fits to the basic structure seen in Phthitia species. Epiproct (Fig. 132) comparatively weak, subtriangular, with a pair of caudal apical processeswith two pairs of short setae. Hypoproct (Figs 131-132) broad, weakly sclerotised medially, almost bare. Female cercus (Figs 131-132) strongly upcurved apically, with two thick apical thorns. Spermathecae (Fig. 133) pyriform, ducts sclerotised on a short section distally to spermathecae, paired spermatheca with a single common duct, not with individualized ducts. Spermathecae on its basal, narrowed part with some minute warts.

Etymology. I named this new species (Latin 'incognitus'= not related), since one cannot find a closer relative species among the Afrotropical species.

Comments. I could not find any species in MARshall and Smith's (1992) a revision of the New World Atlantic and Pacific Phthitia close to this new species. In their interpretation of Kimosina Roháček, 1983 is synonymous with Phthitia. As stated in PApP (2008a), we should keep Kimosina at least as a subgenus of Phthitia. This new species does not fit into Kimosina or to the subgenera Collimosina Roháček (1983), Alimosina Roháček (1983) or Rufolimosina L. Papp, 2008.

\section{Phthitia (Kimosina) vulgaris sp. n.}

(Figs 134-143)

Holotype (HNHM): male, RSA: Eastern Cape Prov., Hogsback, 39 Steps Waterfall, Jan 7-8, 2007 - GPS06, S32 35' 22.8' E26 55' 57.5”', 1233 m, L. Papp \& M. Földvári.

Paratypes: 3 females (HNHM): same data as holotype; 1 male (HNHM): ibid., in a park, No. 8 - Jan 8-9, GPS05, S32 ${ }^{\circ} 35^{\prime} 18.0^{\prime \prime}$ E26 $56^{\prime}$ 56.0', 1,298 m; 1 male (HNHM, gen. prep.): KwaZulu Natal, N Drakensberg, Rainbow Gorge, Jan 26-28, 2007, No. 39 - GPS29, S28 ${ }^{\circ}$ 57' 36.7' E29 $13^{\prime} 33.6^{\prime \prime}, 1,529$ m, L. Papp \& M. Földvári; 1 male (HNHM): ibid., Rainbow Gorge, Jan 26-28, 2007, No. 39 - GPS29, S28 57' 36.7' E29 ${ }^{\circ} 13^{\prime} 33.6^{\prime \prime}, 1,529$ m, L. Papp \& M. Földvári; 1 male (HNHM): ibid., over along Mpofane River, Jan 29, No. 42 GPS32, S29 03' 12.7' E29 23' 06.2' ', 1,531 m. 4 males (BMSA): Malaise trap (2), straddling Mahai River - RSA: KZN, Royal Natal Park, Mahai River at: $28^{\circ} 41.364^{\prime} \mathrm{S} 28^{\circ} 56.335^{\prime} \mathrm{E}$, 17-18.ii.2010, 1449m, A.H. Kirk-Spriggs - [blue] Entomology Dept. ... - BMSA(D) 19944, 19945, 19947, 19948; 1 male 2 females (BMSA): Malaise trap, Leucosedea dominated scrub - [as above], Thendele, 1,600 m, 28 42.378'S 28 56.083'E, 15-17.ii.2010 - [blue] Entomology Dept. ... - BMSA(D) 21554, 20817, 20772; 1 female (BMSA): RSA: KZN, Ndumo Game R., main camp at: $26^{\circ} 54.652^{\prime} \mathrm{S} 32^{\circ} 19.719^{\prime} \mathrm{E}, 27-30 . x i .2009$ - [blue] Entomology Dept. ... BMSA(D) 14915.

Size (in mm): body length 1.88 (holotype), 1.85-1.94 (paratypes); wing length 1.95 (holotype), 1.84-1.96 (paratypes); wing width 0.87 (holotype), 0.78-0.88 (paratypes).

Description. Male. Head. Four pairs of interfrontals (anterior pair short). Postocellar seta distinct, inclinate, not crossing. Two large latero-clinate fronto-orbital pairs, plus several short fronto-orbital setulae on lower half of orbits. Ocellar, outer, and inner verticals, 
outer and inner ocellar pairs strong. Parafacialia with thin, $0.03-0.04 \mathrm{~mm}$ long setulae. First flagellomere rounded. Arista $0.68 \mathrm{~mm}$, cilia max. $0.02 \mathrm{~mm}$. Gena $0.15-0.16 \mathrm{~mm}$, broad below eye. Vibrissa medium-long, $0.22-0.23 \mathrm{~mm}$, first peristomal $0.08-0.10 \mathrm{~mm}$. Genal seta, 0.15-0.17 mm long. Thorax. (1) 2-3 pairs of dorsocentrals, strongly weakening anteriorad. Prescutellar seta very long. Acrostichal setae in 10 rows anteriorly. A single strong lateral plus a medio-clinate ppnt present. Two notoplaural pairs (posterior pair on a conical protuberance), 1 true long supra-alar, a presutural $p a$ and a posterior $p a$. Anterior katepisternal seta short $(0.07 \mathrm{~mm})$, posterior pair $0.20 \mathrm{~mm}$. Apical scutellar seta very long $(0.58-0.62 \mathrm{~mm})$. Fore leg normal. Male mid tibia distinctly curved, ventro-apical seta thick, $0.07 \mathrm{~mm}$ long. Mid femur with an antero-ventral row of short thick setae on basal 1/4, a sub-basal patch of dense, short thick setae ventrally; mid femur with a row of anterior setae, subapical one particularly thick and long. Male mid tibia with a row of thick black setae, ca. $0.03 \mathrm{~mm}$. Mid tibial armature: anterodorsals at 16/43 (strong), 28/43 (short), 31/43 (strong), posterodorsals at 16/43, 30/43 (strong). Sub-anteriorsetae at 28/43 (weak) and 32/43 (strong). A long posterior apical seta present. Female mid tibia with longer ventro-apical seta $(0.11-0.14 \mathrm{~mm})$, with a distinct mid ventral seta. No dorsal preapical on hind tibia. Two costagial setae of 0.175-0.19 mm, 2 perpendicular setae basal to $\mathrm{Hu}$, and three setae $\mathrm{Hu}$, long setae on Cs1. Sections Cs2 and Cs3, respectively $0.675 \mathrm{~mm}$ and $0.65 \mathrm{~mm}$, costal ratio 1.04 . C runs to apex of $\mathrm{R}_{4+5}$. RM-MM section $0.27 \mathrm{~mm}, \mathrm{M}-\mathrm{M}$ cross-vein $0.12 \mathrm{~mm} . \mathrm{R}_{4+5}$ upcurving along entire length. $M_{1+2}$ slightly sigmoid, reaching wing margin. Discal cell edged, $M_{3+4}$ extension on a section longer than M-M. Alula separated from the rest of wing by a deep incision, alula ca. $0.05 \mathrm{~mm}$ broad, with long medial cilia. Halter dark brown. Abdomen. Sternite 5 (Fig. 134) large, a rather large caudal, less sclerotised area; sternite 5 with numerous caudal and subcaudal setae. Synsternite with a structured ventral part of sternite 6 portion (Figs 135-136): three layers of structures medially; a blunt bifid sclerite less ventrally, a small, short but broad lamella more ventrally, a forked lamella with short but broad base most ventrally. Epandrium open ventrally (Fig. 137), cercus connected to epandrium by a narrow neck. Subepandrial sclerite (Fig. 140) consisting of a long narrow sagittal part and a pair of lateral arms with similar shape. Hypandrium (Fig. 138) strongly fused to epandrium, medial apodeme ("rod") asymmetrical, short and broad. Surstylus (Fig. 141) rather small, divide into three ventrally, caudal lobe with a narrow, digitiform process, two thick black thornlets. Basiphallus (Fig. 142) connected to phallapodeme by postgonite; basiphallus rather small, broadened distally into a small epiphallus. Distiphallus (Fig. 142) not large, numerous short and medium-long hairs, apical part narrowed and downcurved. Phallapodeme not broadened. Postgonite (Fig. 139) largely J-shaped, with short but broad base, apical 3/5 anteriorly curved, apex narrow but not sharp.

Female. Spermathecae (Fig. 143) globular, paired spermathecae with a short specific sclerotised duct, common duct also short, with a distal bulb; sclerotised duct of the single spermatheca somewhat longer. No discernible structures found on surface of spermathecae.

Etymology. The specific epithet of the new species (Latin 'vulgaris' $=$ common) refers to its abundance.

Comments. In order to recognize described species that could be related to Phthitia vulgaris sp. n., we used Marshall and Smith's (1992) key for the New World, Atlantic and Pacific Phthitia. We reach couplet 13 with Ph. vulgar- 

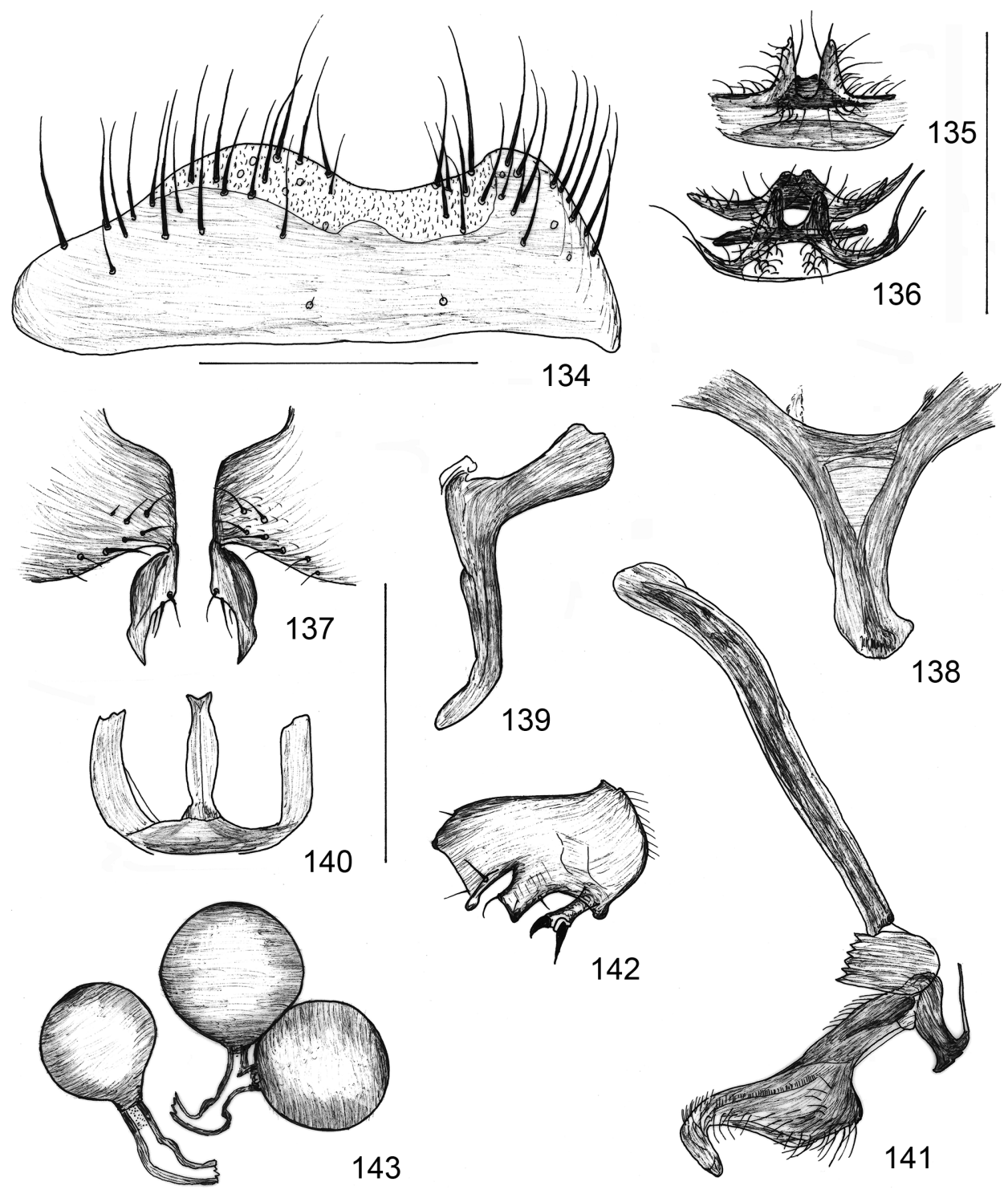

Figs 134-143. Phthitia (Kimosina) vulgaris sp. n., male postabdomen and genitalia, and female spermathecae. $134=$ male sternite 5 , ventral view, $135=$ ventral part of sternite 6 portion of the synsternite, ventral view, 136 = same, caudal view, $137=$ ventral part of epandrium with cerci, caudal view, $138=$ hypandrium, ventral view, $139=$ postgonite, broadest (sublateral) view, 140 = subepandrial sclerite, anterior view, $141=$ surstylus, broadest (sublateral) view, 142 = phallus and phallapodeme with base of postgonite, $143=$ spermathecae. Scale bar: $0.2 \mathrm{~mm}$ for Figs 134-143 
is, but it then does not fit any of the alternatives. After couplet 18 (which seems to be the better choice), through couplets $19,20,21$, and 22 , we can reach two Nearctic species that differ considerably in their male genital structure from Phthitia vulgaris sp. n. Features of some Phthitia species in that excellent paper fit this new species: e.g., the cercus of Ph. digistylus Marshall (fig. 63), or the subepandrial sclerite of Ph. nigrifacies Marshall (fig. 130). Indeed, no very close relative seems to be present among the species in MARshaLL and SMITH (1992).

\section{Piliterga africana sp. n.}

(Figs 144-151)

Holotype (HNHM): male, Nigeria [Bauchi State]: Yankari (on label incorrectly Yangui) Reserve, Wikki - Aug. 15, 1978, leg. A. Demeter, No. 22 [buffalo dung from previous night].

Paratypes (HNHM): 9 males, 22 females: same data as holotype; 1 female: ibid., Aug. 3, 1978, leg. A. Demeter, No. 2 [several days old elephant dung]; 1 female: ibid., Aug. 14, No. 16 [fresh buffalo dung]; 1 male: ibid., Aug. 14, No. 17 [buffalo dung from the previous night]; 1 male 1 female: ibid., Aug. 14, No. 18 [hippo dung from previous night]. 3 males (1 with gen. prep.) 1 female: TANZANIA: Morogoro region, Mikumi National Park, Mikumi Tented Camp - Netting over excrement of elephant, Feb 1, 1987, leg. S. Mahunka - T. Pócs - A. Zicsi, No. 8. (The specimens in the HNHM are defected and wrinkled since they were pinned from alcohol, where they were preserved for a decade.)

Paratypes (BMSA): 1 male (gen. prep.) 1 female: Malaise traps, Ficus forest - RSA: KZN, Ndumo Game R., Shokwe area at: $26^{\circ} 52.125^{\prime}$ S, $32^{\circ} 13.731^{\prime}$ E, 30.xi.-4.xii.2009, A. H. Kirk-Spriggs - [blue] Entomology Dept. National Museum, P.O.Box 266, Bloemfontein 9300, South Africa -BMSA(D) 16589 / 16107.

Size (in mm): body length 1.38 (holotype), 1.31-1.42 (paratypes); wing length 1.23 (holotype), 1.21-1.56 (paratypes); wing width 0.59 (holotype), 0.57-0.63 (paratypes).

Deascription. Male. Body colour light brown, anterior half of frons, humeral callus, pleura (partly) and legs, reddish yellow. Head, thorax and legs (including 5 setae on mid tibia) as in $P$. thaii. Facial plate concave in profile, mouth edge upturned. Anterior half of frons reddish yellow. Longitudinal diameter of eye $0.23-0.24 \mathrm{~mm}$, gena below eye, 0.10 $\mathrm{mm}$. Parafacialia in distinct width with conspicuous ( $0.04 \mathrm{~mm}$ long) hairs. Four (right side) or five (left side) rather long interfrontals. Head setae strong (including outer and inner occipitals), postocellar seta $0.05 \mathrm{~mm}$ or even longer. Vibrissa $0.15 \mathrm{~mm}$, first peristomal seta 0.06-0.07 mm. Genal seta strong, 0.10-0.11 mm long. Scape weak, broader than long, with a $0.05 \mathrm{~mm}$ long medial seta. Pedicel conical, with long setae, dorsal seta of $0.08 \mathrm{~mm}$. First flagellomere wider than long (length $0.09 \mathrm{~mm}$; width $0.11 \mathrm{~mm}$ ), much longer than pedicel, with a conical (but not sharp) dorsal apex. Arista $0.54 \mathrm{~mm}$ long. A second, reduced postpronotal seta discernible. Thoracic setae, including 2nd notopleural (or lateral presutural) strong. A second anterior dorsocentral pair also developed. Prescutellar acrostichal seta very long, $0.15 \mathrm{~mm}$. Anterior katepisternal seta short $(0.05 \mathrm{~mm})$, posterior kepst long, 0.18-0.20 mm. Wing clear, veins light brown. Sub-basal seta on C $0.12 \mathrm{~mm}$. Second costal section (paratype) $0.30 \mathrm{~mm}$, third section $0.42 \mathrm{~mm}$, costal ratio $0.72 . \mathrm{R}_{4+5}$ terminates at wing apex. RM-MM section of $\mathrm{M}_{1+2} 0.14 \mathrm{~mm}, \mathrm{M}-\mathrm{M}$ crossvein $0.09(0.08) \mathrm{mm}$. Discal cell edgy, but $\mathrm{M}_{3+4}$ mostly not continued distally or visible as a colourless fold of $0.12-0.15 \mathrm{~mm}$. Anal vein 
angled. Alula very narrow but apex narrowly rounded. Mid tibia with antero-dorsals at $4 / 15$, at $2 / 3$, postero-dorsals at $2 / 6,4 / 5$, a more dorsal at $5 / 6$. No mid ventral seta. Both ventro-apical and anterior apical setae strong. Abdomen. Longest setae on second abdominal tergite (Fig. 144) $2 / 3$ as long as T1+2 combined (4/5 as long as in P. thaii, cf. PApp 2008a: fig. 31). Tergites 2 to 4 not so reduced. Sternite 5 (Fig. 145) long, elongated into a caudal stripe with ca. 8 long setae, continued into a transverse short setose caudal process (Fig. 146, cf. PAPr 2008a: fig. 36), with apex more caudal than that of tergite 5. Caudal edge of sternite
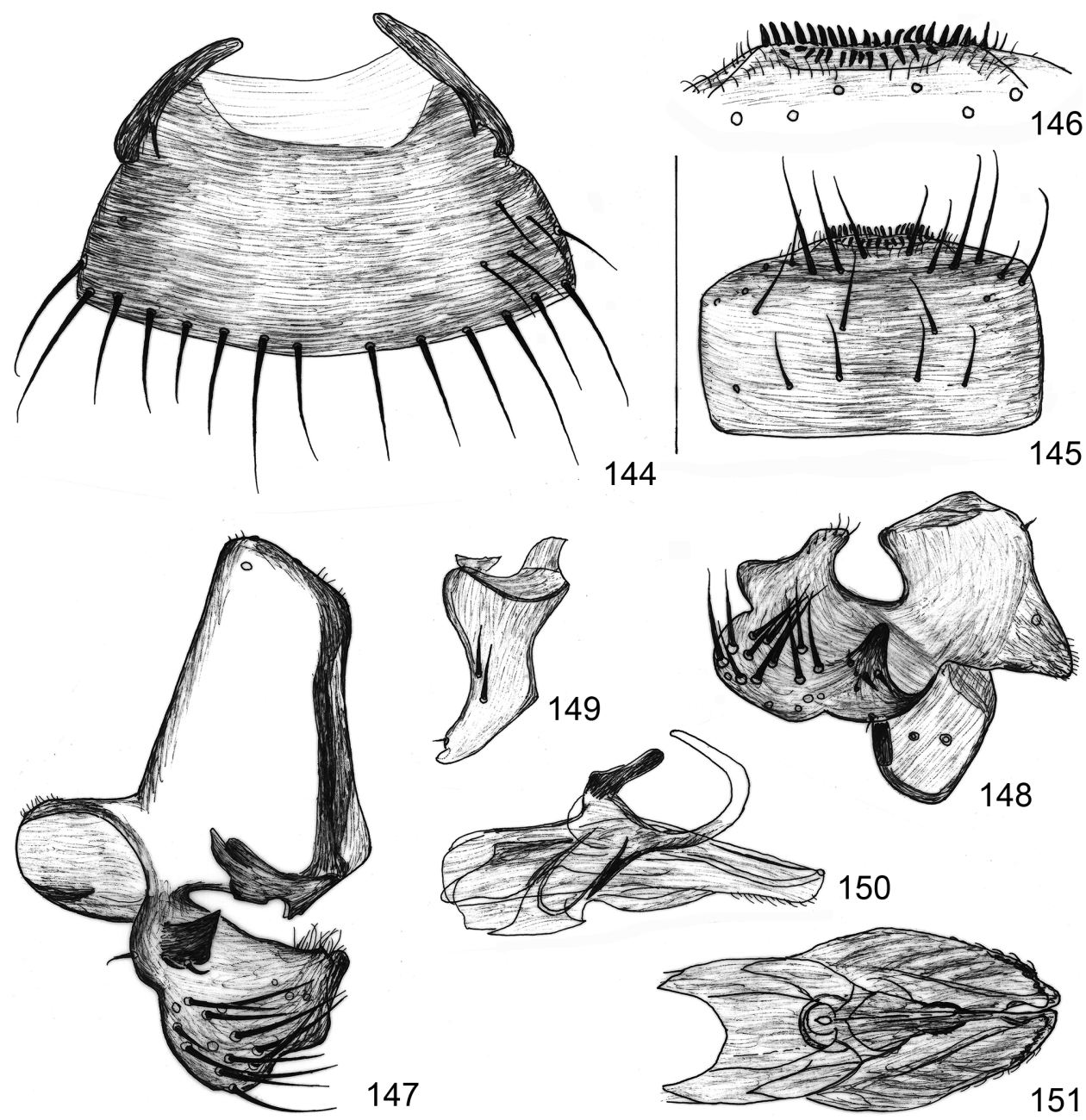

Figs 144-151. Piliterga africana sp. n., male abdomen and genitalia. $144=$ male tergite 1 and 2, dorsal view, $145=$ sternite 5, ventral view, $146=$ caudal part of sternite 5 in higher magnification, 147 = epandrial complex with right surstylus, medial (inner) view, $148=$ surstylus, in broadest view, $149=$ postgonite, lateral view, $150=$ distiphallus, lateral view, 151 = distiphallus, ventral view. Scale bar: 0.2 mm for Figs 144-145, $0.1 \mathrm{~mm}$ for Figs 146-151 
5 with short black pegs in 2 rows. Sternite 6 portion of synsternite extending anteriorly, not caudally; sternite 6 and sternite 7 portions with two strong setae each, sternite 6 setae longer. Sternite 7 and 8 portions strongly fused, free part of sternite 7 medially curved with an incurved sclerite. Ventro-posterior edge of epandrium (Fig. 147) square or with a short projection. Caudal and ventral edges of epandrium with dark, thick sclerotisation, discernible in inner (medial) view (Fig. 147). Surstylus (Figs 147-148) 3-lobed. Lobes of surstylus movable in relation to its "body", so relative positions not entirely fixed; setose ventral lobe strongly medio-clinate. Postgonite (Fig. 149) broad-based, apical 3/7; anteriorly curved, with 2 small blunt apices; anterior edge of postgonite with 2 pairs of strong dorsally directed setae. Postgonite in cavity of surstylus. Phallapodeme longer and without dorsal ridge medially. Distiphallus with a paired dark dorsal process, recurved one in sagittal plane (Figs 150-151), with a pair of apical ventral lobes with short hairs.

Etymology. The specific epithet of this new species refers to its type locality in Africa.

Comments. The genus Piliterga was described based on a single Oriental species, P. thaii L. Papp, 2008. The original description (PAPP 2008a: 63) already mentioned that "[in] the collection of the HNHM there is another species of the genus from the Afrotropical region (Tanzania, Nigeria) ... described elsewhere", which is the species described here. The thin recurved dorsal process of distiphallus seems to be a strong synapomorphy of the genus. Angle of anal vein in Piliterga africana sp. $\mathrm{n}$. not as strongly as in species of Coproica. In $P$. thaii, differently from $P$. africana sp. n., the sternite 7 portion of the synsternite has only, but longer than those of sternite 6 portion. Also, in P. africana sp. $\mathrm{n}$. the ventral caudal edge of epandrium is rounded and the surstylus is 3-lobed, differently from that of $P$. thaii.

\section{Setositibiella secunda sp. $n$.}

(Figs 152-159)

Holotype (BMSA): male, Malaise traps, Circumguinean forest, BURUNDI: Bururi Prov., Réserve Naturelle Forestière de Kigwena, $04^{\circ} 05.949^{\prime} \mathrm{S}, 2^{\circ}{ }^{\circ} 30.455^{\prime} \mathrm{E}, 17-20 . x i .2010$, 810m, A. H. Kirk-Spriggs - [blue] Entomology Dept. National Museum, P.O.Box 266, Bloemfontein 9300, South Africa - BMSA(D) 24401.

Size (in mm): body length 2.36 (holotype), wing length 2.14; wing width 0.97 .

Description. Male. Black, only mid and hind tarsi blackish. Scutum and scutellum granulated, sub-shiny. Scutellum very large. Width of head $0.65 \mathrm{~mm}$, width of thorax 0.69 $\mathrm{mm}$, width of scutellum $0.48 \mathrm{~mm}$, length of scutellum $0.30 \mathrm{~mm}$. Frons short and broad, twice wider than long. Facial plate (prefrons) shiny, a shallow concave groove below antenna. Three pairs of medium-long interfrontals, anterior fronto-orbital thin, short lateroclinate, slightly proclinate, posterior pair strong $(0.23 \mathrm{~mm})$. All ocellar, outer and inner vertical setae strong. Postocellars minute, occi weak, swell separate from each other. Both outer and inner occipital setae thin, only $1 / 3$ as long as verticals. Scape and pedicel yellow, first flagellomere dark grey. Eye large, gena narrow, $0.05 \mathrm{~mm}$ broad below eye, vibrissa long, $0.23 \mathrm{~mm}$. Setae on pedicel particularly strong, dorsal subapical seta of $0.12 \mathrm{~mm}$. First 
flagellomere about twice higher than long, arista extremely long, $1.00 \mathrm{~mm}$ with $0.03 \mathrm{~mm}$ long cilia. Longest cilia on first flagellomere $0.04 \mathrm{~mm}$. One postpronotal, two notopleurals (posterior pair on a conical tuberance), 1 very long lateral post-alar, 1 short post-alar at intra-alar line, two pairs of strong dorsocentrals. Scutellars strong, apical pair of $0.42 \mathrm{~mm}$. Wing comparatively short, rounded. Membrane light brown, costal area darker, veins ochre. Veins rather thick (radials $0.015 \mathrm{~mm}$ ), setulae on membrane long. Costal vein overruns/surpasses apex of $R_{4+5}$ by $0.03-0.04 \mathrm{~mm}$. Cs2 $0.69 \mathrm{~mm}$, Cs3 0.53, costal index, 1.29. $\mathrm{M}_{1+2}$ not reaching wing margin, RM-MM $0.18 \mathrm{~mm}, \mathrm{M}-\mathrm{M}$ cross-vein $0.11 \mathrm{~mm}$. Discal cell without appendages of $\mathrm{M}$ veins. Alula small, very narrow with long $(0.05 \mathrm{~mm})$ cilia apically and

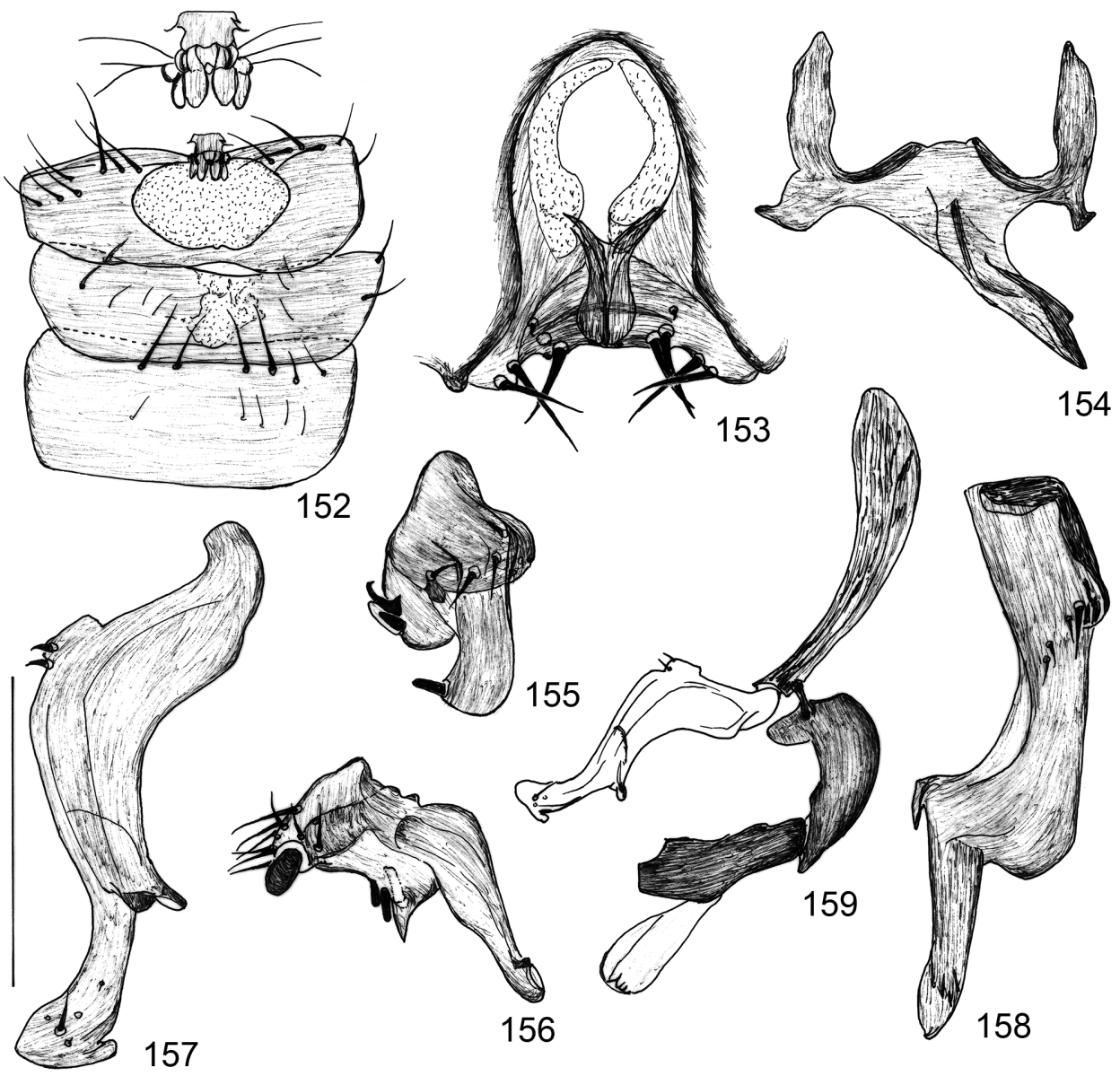

Figs 152-159. Setositibiella secunda sp. n., holotype male abdomen and genitalia. $152=$ sternites 3 to 5, ventral view (outset: caudal part in higher magnification), 153 = ventral part of epandrium, cerci with subepandrial sclerite (partly covered), caudal view, $154=$ hypandrium, ventral view, 155 = surstylus, ventral view, $156=$ surstylus, lateral view, $157=$ postgonite, lateral view, $158=$ postgonite, anterior view, $159=$ phallus, phallapodeme and postgonite, lateral view. Scale bar: $0.4 \mathrm{~m}$ for Fig. 152, $0.2 \mathrm{~mm}$ for Figs 153-156, $0.1 \mathrm{~mm}$ for

Figs $157-159$ 
medially. Mid tibial armature strong, ventrally with several long setae of $0.15-0.18 \mathrm{~mm}$, plus a row of short thick black thornlets ventrally. Male ventro-apical seta, $0.08 \mathrm{~mm}$ long. Antero-dorsal setae at 20/46, 38/46 (both very long, $0.18 \mathrm{~mm}$ ) and at $14 / 46$, postero-dorsals at 25/46, 36/46, a short dorsal at 33/46. Hind tibia with a $0.42 \mathrm{~mm}$ long dorsal preapical seta. Claws normal. Male abdominal sternites 3 to 5 very characteristic (Fig. 152): sternite 3 long, with two pairs of strong setae. Sternite 4 on a smaller medial part, sternite 5 on a large medio-caudal part bearing a less sclerotised and melanised area each. Medio-caudal part of sternite 5 with a small sclerotised structure of several small lamellae better seen in higher magnification. Ventral part of epandrium (Fig. 153) with cerci fused sagittally which bear 4 pairs of long thick black thorns; cercus without ventral process. Subepandrial sclerite definitely high. Hypandrium (Fig. 154) robust, with slightly asymmetrical arms and an asymmetrical rightwards curved medial appendage. Surstylus (Figs 155-156) with caudal lobe rather narrow, bare, medial lobe short, apical lobe broader and shorter. Phallapodeme (Fig. 159) small, basiphallus shorter, distiphallus differently shaped. Postgonite (Figs 157-158) with a caudal lobe on apical third, apex broadened, curvature on apical third (in anterior/caudal view) much stronger.

Etymology. The specific epithet of this new species is from the Latin name 'secundus' (second), referring to the fact, that this is the second known species of the genus.

Comments. S. secunda sp. n. is actually differing from the type species of the genus by the details of the male genitalia as demonstrated in the description above. The mid tibial armature as strong as in S. terrestris. Sternite 3 about twice longer than in $S$. terrestris and it bears not 1 but 2 pairs of strong setae (cf. PAPP 2008a: fig. 287). The medio-caudal part of sternite 5 with a small sclerotised structure very different from that of $S$. terrestris, cf. PAPP 2008a: fig. 286). The cercus without a ventral process is similar to S. terrestris. The subepandrial sclerite definitely higher than that of S. terrestris (PAPP 2008a: fig. 290). The shape of the surstylus of $S$. secunda is very different from the surstylus of S. terrestris (PAPP 2008a: figs 293-294). The phallapodeme (Fig. 159) much smaller than in S. terrestris (PAPP 2008a: fig. 291). The postgonite differs from that of S. terrestris (PAPP 2008a: figs 291-292) in details: it has a caudal, not an anterior lobe at distal third.

\section{Spelobia foldvarii sp. $\mathrm{n}$. \\ (Figs 160-165)}

Holotype (HNHM): male, TANZANIA: Morogoro region, Mikumi National Park, Mikumi Tented Camp - Netting over excrement of elephant, Feb 1, 1987, leg. S. Mahunka - T. Pócs - A. Zicsi, No. 8.

Paratypes (HNHM): 10 males (2 males with gen. prep.) 2 females: same labels as for the holotype.

Size (in mm): body length 1.92 (holotype), 1.82-1.96 (paratypes); wing length 1.93 (holotype), 1.76-1.95 (paratypes); wing width 0.86 (holotype), 0.82-0.94 (paratypes). 
Description. Head. 3-4 strong interfrontals (differing on both sides of same specimens, including holotype), 1 short interfrontal seta just above lunule. Numerous orbital setulae on anterior $3 / 5$ of orbits. Two upper orbitals, outer and inner vertical pairs strong and thick, outer and inner occipitals strong and thick, ca. $0.15 \mathrm{~mm}$ long, postocellar pair

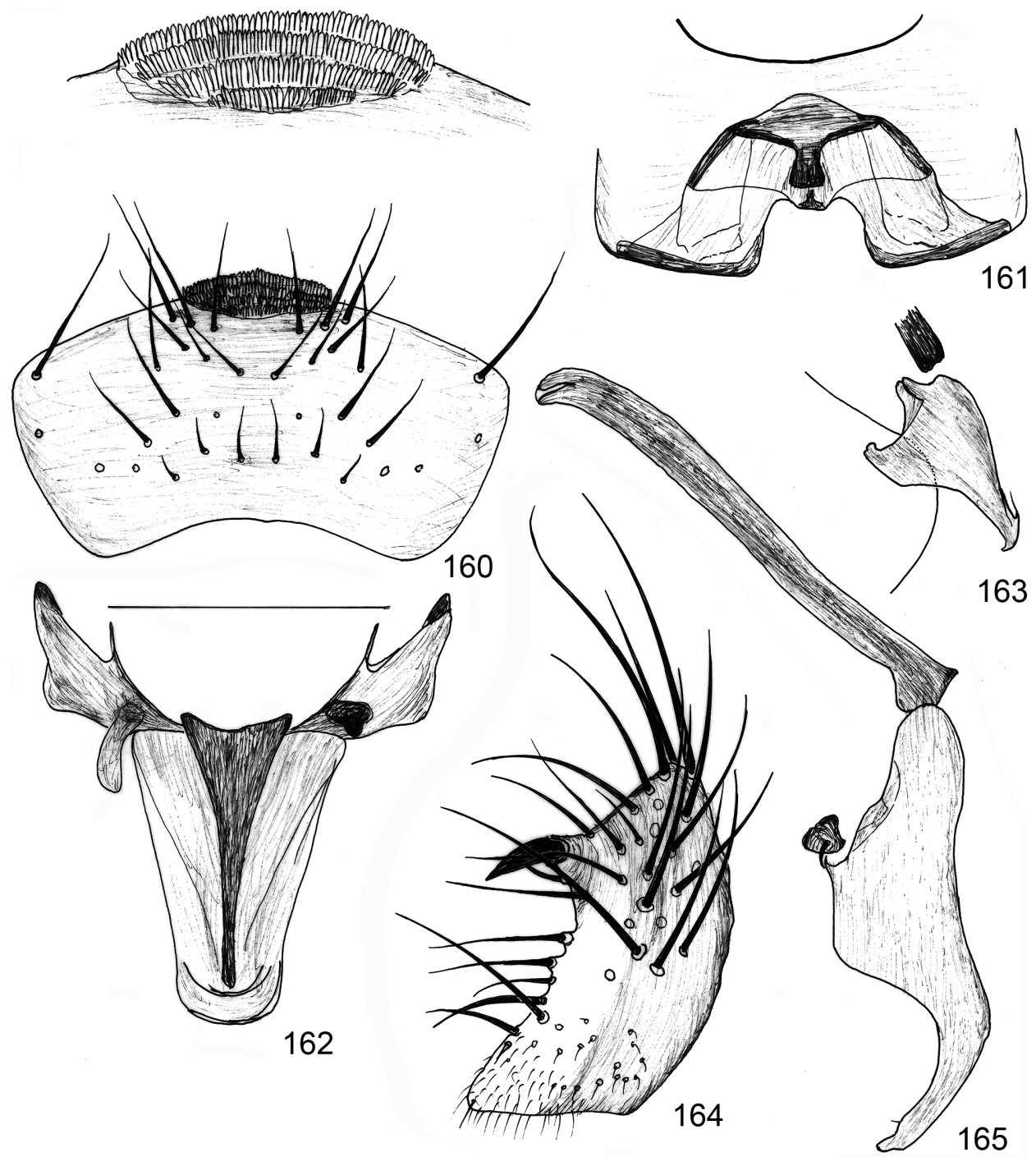

Figs 160-165. Spelobia foldvarii sp. n., male postabdomen and genitalia. $160=$ sternite 5, ventral view (outset: caudal part in high magnification), $161=$ subepandrial sclerite with the cercal part of epandrium, anterior view, $162=$ hypandrium, ventral view, $163=$ basiphallus, lateral view, $164=$ surstylus, in broadest (sublateral) view, $165=$ postgonite with phallapodeme, lateral view. Scale bar: $0.2 \mathrm{~mm}$ for Fig 160, $0.1 \mathrm{~mm}$ for the rest 
weaker. Arista with long, $0.025-0.03 \mathrm{~mm}$ cilia, apical cilia on first flagellomere, $0.025 \mathrm{~mm}$ long. Presutural acrostichals at most $0.10 \mathrm{~mm}$ (broken most of the type specimens); two pairs of strong dorsocentrals, acrostichals in ca. 10 irregular rows anteriorly; only two pairs of scutellars, no additional setulae on scutellum. A single strong $(0.20-0.22 \mathrm{~mm}$ long) posterior katepisternmal seta, one short $0.045-0.05 \mathrm{~mm}$ anterior katepisternal present. Anterior femur of male simple. Antero-dorsal setae on mid tibia at 12/49 (short), 18/49 (strong), 31/49 (medium-long), 36/49 (strong), 44/49 (medium); a long rather dorsal seta at 40/49; postero-dorsal setae at 14/49 (weak), 22/49 (weak), 40/49 (strong). A strong medio-ventral seta at 29/49. Fore tarsi black and strongly, flattened. Mid tarsi black, not particularly modified, $0.30-0.31 \mathrm{~mm}$, with medium-long anteroventral and posteroventral rows of setae of similar length. Hind tarsi dark, extremely flattened. Claws thin. Wing membrane light brown, veins ochre or light brown. Second costal section $0.63 \mathrm{~mm}$, third section $0.54 \mathrm{~mm}$, RM-MM section of $\mathrm{M}_{1+2} 0.25 \mathrm{~mm}, \mathrm{M}-\mathrm{M}$ cross-vein $0.12 \mathrm{~mm}$. Alula narrow, only $0.07-0.08$ mm wide. Male sternite 5 (Fig. 160) rather long, with a limited number of long setae. Sternite 5 medio-caudally with numerous short black pegs in four rows at outset of caudal part in high magnification. Cercal part of epandrium without any cercal projection (Fig. 161). Subepandrial sclerite ventrally aligned with ventral edge of cercal part of epandrium (Fig. 161). Hypandrium (Fig. 162) with extremely broad medial part. Basiphallus (Fig. 163) strongly narrowed ventrally. Surstylus (Fig. 164) unique for its long setae and hairy apex; ventral thorn on a conical protuberance. Phallapodeme without a dorsal ridge. Postgonite (Fig. 165) wider on basal half.

Etymology. This species is named to the honour of Dr. Mihály Földvári, who was my partner on several exotic expeditions, and contributed much to the Collection of the Hungarian Natural History Museum.

Comments. Spelobia foldvarii sp. n. keys in to couplet 13 in RoHÁčEK's (1983) key to the European species of Spelobia. However, no European species seems to be directly related to $S$. foldvarii $\mathrm{sp}$. $\mathrm{n}$. The four rows of pegs on the medio-caudal part of male sternite 5 is characteristic, although e.g. S. palmata or S. simplicipes have more than 2 rows of pegs there. The basiphallus of the new species is strongly narrowed ventrally in profile, a unique character in Spelobia. The shape and armature of the surstylus alone would be enough to recognize this species. The thoracic chaetotaxy of $S$. foldvarii is as in the other species of Spelobia. In S. foldvarii the postgonite is much wider on basal half than in the European species.

\section{Terrilimosina improvisa sp. $\mathrm{n}$. (Figs 166-173)}

Holotype (HNHM): male, CONGO, Kindamba, 5. XI. 1963, No. 109, J. Balogh - A. Zicsi.

Paratype male (HNHM, abdomen, mid and hind legs prepared and kept in a plastic microvial with glycerol): same data as holotype.

Size (in mm): body length 1.94 (holotype), 1.83 (paratype); wing length 1.73 (holotype), 1.69 (paratype); wing width 0.73 (holotype), 0.71 (paratype). 
Description. Male. Head. Facial plate deeply concave in profile, with 2 large deep impressions. Antennal bases broadly separated. 3 very long pairs of interfrontals. Both pairs of fronto-orbitals strong, plus several short fronto-orbital setae present. All outer and inner verticals, outer and inner occipital pairs very strong. Postocular pair hardly discernible. Scape minute, with a $0.05 \mathrm{~mm}$ long medial seta. Pedicel large, conical, with a circlet of long apical setae and $3 \mathrm{ca} .0 .10 \mathrm{~mm}$ long dorsal setae. First flagellomere with long $(0.03$ $\mathrm{mm}$ ) cilia. Arista with long cilia of similar length. Eye strongly reduced, its longitudinal diameter $0.22 \mathrm{~mm}$, gena below eye $0.15 \mathrm{~mm}$ broad. Parafacialia broad, with a row of 3-4
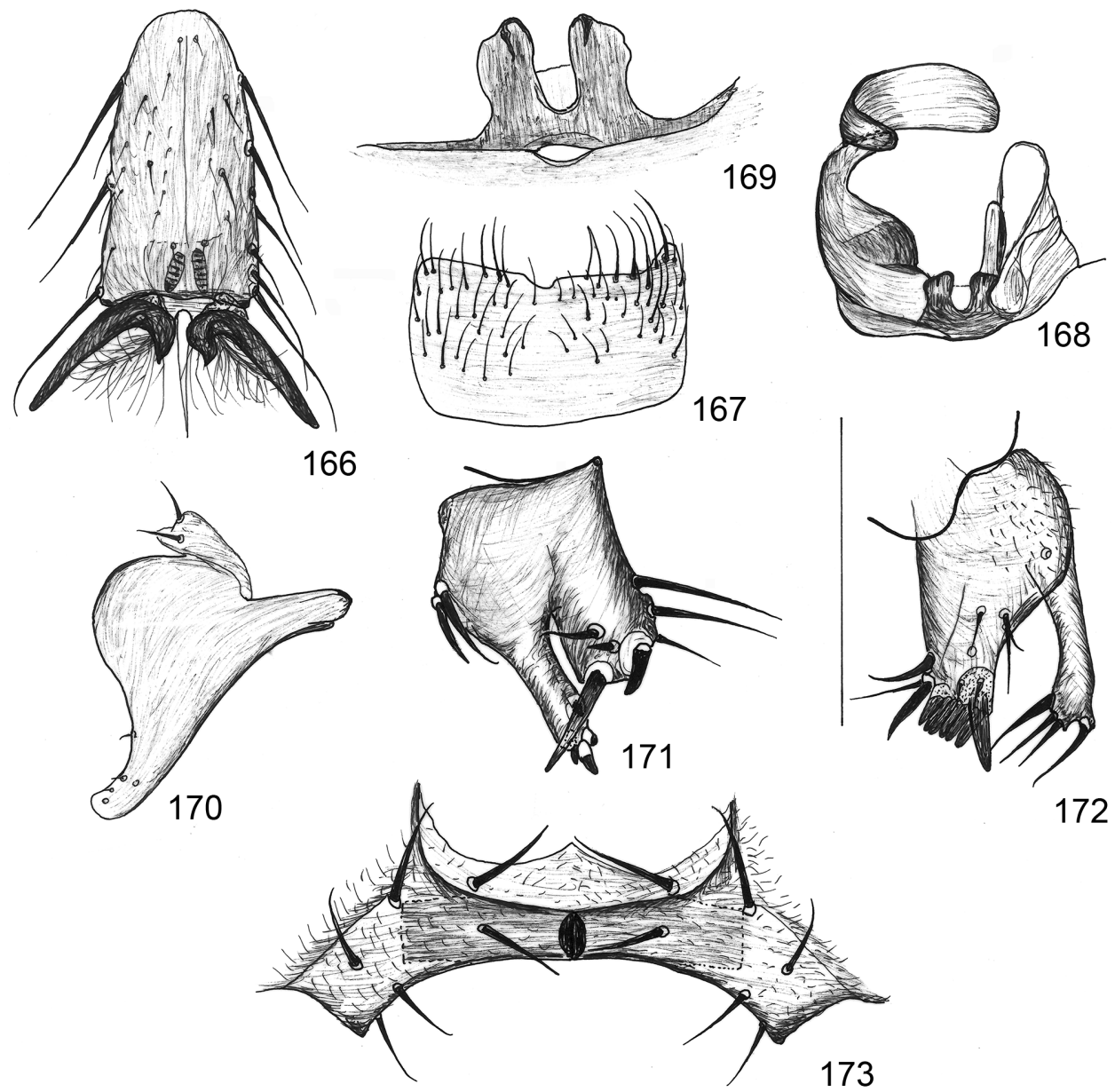

172

Figs 166-173. Terrilimosina improvisa sp. n., male. $166=5^{\text {th }}$ tarsomere of the hind leg, ventral view (dorsal setae omitted), $167=$ sternite 5 , ventral view, $168=$ ventral part of sternite 6 portion of synsternite, ventral view, $169=$ synsternite, subventral view, $170=$ postgonite, lateral view, $171=$ surstylus, lateral view, $172=$ surstylus, caudal view, $173=$ cercal part of epandrium with subepandrial sclerite (covered), caudal view. Scale bar: $0.4 \mathrm{~mm}$ for Figs 166, 167, $0.2 \mathrm{~mm}$ for Fig 168, $0.1 \mathrm{~mm}$ for Figs 169-173 
setulae of $0.05-0.07 \mathrm{~mm}$. Vibrissa strong, $0.26 \mathrm{~mm}$ (from base to tip), medially curved. Peristomals thin, not longer than $0.05 \mathrm{~mm}$. No strong genal seta, but only some thin setulae on ventral half of gena. Only one pair of dorsocentral setae, other setae along dorsocentral line, hardly longer than acrosticals; two pairs of long scutellars, apical scutellar seta, 0.50 $\mathrm{mm}$ long. One postpronotal, two notoplaurals (posterior one on a callus), one pre-sutural, one supra-alar, two postalars (lateral one $0.28 \mathrm{~mm}$ long). One pair of very strong katepisternal seta. Wing membrane light brownish, veins ochre, costal vein darker. Apex of $R_{4+5}$ near to apex of wing. Discal cell distally rounded, no continuation of $\mathrm{M}_{3+4}$ discernible. $\mathrm{RM}$ to MM $0.31 \mathrm{~mm}$, crossvein M-M $0.11 \mathrm{~mm}$. Alula large, apex rounded. Two $0.12-0.12 \mathrm{~mm}$ long sub-basal setae on costa, costal setae on first section $0.06 \mathrm{~mm}$ long. Second / third costal sections $0.66 \mathrm{~mm} / 0.60 \mathrm{~mm}$, ratio 1.10. Halter light brown. Thoracic calyptra with extremely long $(0.15 \mathrm{~mm})$ cilia. Legs brown, without peculiar modifications. Male fore femur simple. Male mid tibia without strong ventral, but a row of black thorns of ca. 0.03 $\mathrm{mm}$. Mid basitarsus / 2nd tarsomere, 0.285 / $0.19 \mathrm{~mm}$; hind basitarsus / 2nd tarsomere 0.15 / $0.275 \mathrm{~mm}$. Mid tibial armature: anterodorsals at 13/52, 27/52 (both medium long), a very long $(0.15 \mathrm{~mm})$, nearly dorsal at 43/52, posterodorsal at 40/52. All claws normal (Fig. 166). Male postabdomen and genitalia. Sternite 5 (Fig. 167) rather simple, apical 3/4 covered by medium-long setae. Ventral part of sternite 6 portion of synsternite (Fig. 168), with a flat, broad U-shaped sclerite. Synsternite (Fig. 169) with rather small sternite 8 portion, medial edge of sternite 7 portion rounded. Subepandrial sclerite, with large right side scelerites (see PAPp 2008a). Epandrium large, convex; cercal part of epandrium very short, edgy (Fig. 173). Subepandrial sclerite (covered on Fig. 173), short and broad. Surstylus (Figs 171-172) characteristic, with a pair of lobes, anterior lobe digitiform, with 4 apical setae (Fig. 172), caudal lobe larger, with two strong black thorns laterally and with a comb of seven black thorns medio-apically. Postgonite (Fig. 170) very broad basally, anterior contour widely rounded, apical third strongly narrowed, with a narrowly rounded apex.

Female unknown.

Etymology. The specific epithet of this new species refers to the unexpected occurrence of this genus in the Afrotropical Region.

Comments. RoHÁčEK (1983) revised the European species and MARsHALL (1985), the Nearctic species. For the species from China and Japan (probably also with Oriental distribution), see Su and LiU (2009). No new species from Europe or Africa have been described since then. This new species seems to show some similarities with the European species. T. improvisa seems to be closer to T. rakovitzai and to T. sudetica in the U-shaped lamella in their ventral part of sternite 6 portion. Actually, it is quite surprising that this terricolous Afrotropical species (which habits are clearly suggested by the fifth tarsomeres and claws, Fig. 166) and a Holarctic, mainly cavernicolous species, shows to be closely related. There are, however, distinctive characters, as the U-shaped lamella of sternite 6 portion with a narrower gap than the arms (different from T. racovitzai), apical narrowed part of postgonite shorter, not parallel (cf. RонÁčEK 1983: fig. 139). The surstylus of the two species are similar, but the 
anterior lobe of the new species is shorter, with no gap between the lobes (cf. RонÁČEK 1983: fig. 140), posterior lobe less medio-clinate.

\section{NEW LOCALITY DATA ON KNOWN SPECIES}

Lotobia africana (Becker, 1907) - Material examined: 1 male (BMSA): Namibia, Mason Shelter, $21^{\circ} 04^{\prime} 39^{\prime \prime} \mathrm{S}, 14^{\circ} 05^{\prime} 43^{\prime \prime} \mathrm{E}, 09$. iii.2002, A. H. Kirk-Spriggs, Klipspringer dung [blue] Entomology Dept. National Museum, P.O.Box 266, Bloemfontein 9300, South Africa; 1 male (BMSA): Otjikoko - Süd 61, SE 2116Ad, Omaruru 18 Nov 1971 - [blue] Namibian National... Windhoek, Namibia - H5400.

Coproica ashleyi L. Papp, 2015 - Material examined: 7 males 3 females (BMSA): Malaise traps, broad-leafed deciduous woodland - RSA: KZN, Ndumo Game R., main camp at: $26^{\circ}$ 54.652'S 32 $19.719^{\prime}$ E, 27-30.xi.2009 - [blue] Entomology Dept. ... - BMSA(D) 14121, $14252,14255,14258,14260,14261,14262,14868,14870,14872$. 1 male: ex fresh dung of Loxodontha africana (Blumenbach, 1797) (Elaphantidae) on road - Namibia: Mahango Game Reserve at: $18^{\circ} 14^{\prime} 40^{\prime \prime} \mathrm{S}, 21^{\circ} 15^{\prime} 01^{\prime \prime} \mathrm{E}$, 01.i.1999, A. H. Kirk-Spriggs, attracted to fungi bait - [blue] Namibian National...

Coproica hirtula (Rondani, 1880) - Material examined: 1 female: Namibia: Windhoek Dist., Windhoek Academia, 22 $36^{\prime}$ 37's, $17^{\circ} 04^{\prime}$ 02'”E, 26.ii.1998, A. H. Kirk-Spriggs, attracted to fungi bait - [blue] Namibian National...; 1 female (BMSA): RSA: KZN, Ndumo Game R., Shokwe area at: $26^{\circ} 52.125^{\prime}$ S $32^{\circ} 13.731^{\prime} E$, 30.xi-4.xii.2009, A.H. Kirk-Spriggs [blue] Entomology Dept. ... - BMSA(D) 16105.

Leptocera austroafricana L. Papp, 2012 - Material examined: 2 males (BMSA): Malaise traps, indigenous Afromontane forest - BURUNDI: Kayanza Prov., Parc National de la Kibira, Rwegura Sector, $02^{\circ} 55.320^{\prime}$ S, $2^{\circ}$ 30.067'E, 21-26.xi.2010, 2237m, A. H. KirkSpriggs - [blue] Entomology Dept. ... - BMSA(D) 27895, 27896.

Opalimosina mirabilis (Collin, 1902) - Material examined: 2 females (HNHM): RSA: Eastern Cape Prov., Hogsback, Mistyfell House, No. 2, on compost, GPS02, S32 $34^{\prime} 41.0^{\prime \prime}$ E26 55' 23.9'”, 1375 m, Jan 7, 2007, L. Papp \& M. Földvári; 1 female (HNHM): ibid., KwaZulu Natal, S. Drakensberg, Garden Castle, along Mlambonja River - Jan 22, No. 33, GPS21.

Preepiphallus endrodyi L. Papp, 2014 - Material examined: 1 male 1 female (BMSA): Malaise traps, Circumguinean forest, BURUNDI: Bururi Prov., Réserve Naturelle Forestière Kigwena, $04^{\circ} 05.949^{\prime} S, 2^{\circ} 30.455^{\prime}$ E, 17-20.xi.2010, 810m, A. H. Kirk-Spriggs - [blue] Entomology Dept. ... - BMSA(D) 24443; 1 female (BMSA): ibid., Likombo forest, $2 \mathrm{~km} \mathrm{SW}$ Bomane, 1.283495S 23.72358E, 20-22.v.2010 - BMSA(D) 00825. New to Burundi. The females were identified by their locality rather than by their morphology (cf. description of the genus, Papp 2014).

Telomerina flavipes (Meigen, 1830) - Material examined: 1 male (BMSA): Malaise traps, Leucosedea -scrub \& steam bed - RSA: Free State, Harrismith, Nesshurst farm, $28^{\circ}$ 26' 53.3'S, 29 09' 14.2'”, 17-18.ix.2009, A. H. Kirk-Spriggs - [blue] Entomology Dept. National Museum, P.O.Box 266, Bloemfontein 9300, South Africa - BMSA(D) 10629.

Acknowledgements - I would like to express my most sincere thanks to Dr Ashley H. Kirk-Spriggs (National Museum Bloemfontein, South Africa) for the loan of their collection 
of Afrotropical Sphaeroceridae. My special thanks are given to Prof. Dr. Tadeusz Zatwarnicki (Opole University, Poland) for preparing of an excellent photo for me. My thanks are due to Mr János Papp (Régió Lapkiadó Kft., Monor, Hungary) for his help in preparing figure plates and to the two reviewers.

\section{REFERENCES}

DudA, O. (1925): Die aussereuropäischen Arten der Gattung Leptocera Olivier - Limosina Macquart (Dipteren) mit Berücksichtigung der europäischen Arten. - Archiv für Naturgeschichte 90A(1924): 5-215.

Hаскмan, W. (1965): Diptera (Brachycera): Sphaeroceridae (Borboridae). - South African Animal Life, Lund 11: 485-503.

Marshall, S. A. (1985): The genera Xenolimosina and Terrilimosina (Diptera: Sphaeroceridae: Limosininae) in North America. - Proceedings of the Entomological Society of Washington 87: 759-769.

Marshall, S. A. \& Sмith, I. P. (1992): A revision of the New World and Pacific Phthitia Enderlein (Diptera; Sphaeroceridae; Limosininae), including Kimosina Roháček, new synonym and Aubertinia Richards, new synonym. - Memoirs of the Entomological Society of Canada 161: 1-83. https://doi.org/10.4039/entm124161fv

Marshall, S. A., Hall, C. B. \& Hodge, S. (1992): A review of the genus Phthitia Enderlein (Diptera, Sphaeroceridae), in New Zealand, with the description of two new species. - New Zealand Entomologist 32: 48-54. https://doi.org/10.1080/00779962.2009.9722175

Marshall, S. A., Roháček, J., Dong, H. \& Buck, M. (2011): The state of Sphaeroceridae (Diptera: Acalyptratae): a world catalog update covering the years 2000-2010, with new generic synonymy, new combinations, and new distributions. - Acta Entomologica Musei Nationalis Pragae 51(1): 217-298.

Norrbom, A. L. \& PApp, L. (1994): Additional new species and analysis of phylogenetic relationships of Achaetothorax Hedicke (Diptera: Sphaeroceridae). Acta Zoologica Academiae Scientiarum Hungaricae 40(1): 65-86.

PApr, L. (1973a): Sphaeroceridae (Diptera) from Mongolia. - Acta Zoologica Academiae Scientiarum Hungaricae 19: 369-425.

PApp, L. (1973b): Trágyalegyek - Harmatlegyek - Sphaeroceridae - Drosophilidae. In: Magyarország Állatvilága, Fauna Hungariae. XV/2., Akadémiai Kiadó, Budapest, 146 pp. [In Hungarian]

PApr, L. (1983): Three new species of Elachisoma Rondani, 1880 (Diptera: Sphaeroceridae). - Acta Zoologica Academiae Scientiarum Hungaricae 29(4): 451-459.

PAPp, L. (1988): A review of the Afrotropical species of Norrbomia gen. n. (Diptera: Sphaeroceridae, Copromyzini). - Acta Zoologica Academiae Scientiarum Hungaricae 34: 393-408.

PApr, L. (2007): A study of the cow pat Diptera on the Hortobágy, Hungary. - Folia entomologica hungarica 68: 123-135.

PApp, L. (2008a): New genera of the Old World Limosininae (Diptera, Sphaeroceridae). Acta Zoologica Academiae Scientiarum Hungaricae 54 (Suppl. 2): 47-209.

PAPP, L. (2008b) Will the elephant dung flies go extinct after the elephants disappear? - Folia entomologica hungarica 69: 221-228.

PAPp, L. (2014): A review of the Old World species of Ceroptera Macquart, 1835 (Diptera, Sphaeroceridae). - Acta Zoologica Academiae Scientiarum Hungaricae 60(2): 109-155. 
Papp, L. \& Norrbom, A. L. (1992): Taxonomy of the Palaeotropical genus Achaetothorax Hedicke (Diptera, Sphaeroceridae). - Acta Zoologica Academiae Scientiarum Hungaricae 38: 321-344.

PApp, L. \& RoháčEK, J. (2017): 99. Sphaeroceridae (Lesser dung flies). In: KIRK-Spriggs, A. H. (ed.): Manual of the Afrotropical Region, Vol. 2. [in print]

Rони́čEK, J. (1982): A monograph and re-classification of the previous genus Limosina Macquart (Diptera, Sphaeroceridae) of Europe. Part I. - Beiträge zur Entomologie, Berlin 33: 3-195.

RoнÁČEK, J. (1983): A monograph and re-classification of the previous genus Limosina Macquart (Diptera, Sphaeroceridae) of Europe. Part II. - Part III. - Beiträge zur Entomologie, Berlin 33: 3-195; 203-255.

RoháčeK, J. \& Marshall, S. A. (1986): The genus Trachyopella Duda (Diptera, Sphaeroceridae) of the Holarctic Region. - Museo Regionale di Scienze Naturali, Torino, Monografie III (1985), 109 pp.

RoháčeK, J. \& Marshall, S. A. (1988): A review of Minilimosina (Svarciella) Rohácek, with descriptions of fourteen new species (Diptera: Sphaeroceridae). - Insecta Mundi 2: 241-282.

Roháček, J., Marshall, S. A., Norrbom, A. L., Buck, M., Quiros, D. I., Smith, I. (2001): World Catalog of Sphaeroceridae (Diptera). - Slezské zemské museum, Opava, 414 pp.

Su, L. X. \& Liu, G. C. (2009): A review of the genus Terrilimosina from China. - Pan-Pacific Entomologist 85: 51-57. https://doi.org/10.3956/2009-10.1

Vanschuytbroeck, P. (1950): Diptères Sphaeroceridae du Musée du Congo belge. - Annales du Musée du Congo Belge, Tervuren, Série in $8^{\circ}$ (Sciences Zoologiques) 5: 5-46.

Vanschuytвroeck, P. (1951): Contribution à l'étude des Sphaeroceridae africains (Diptera Acalyptratae) (3me note). - Bulletin Institut royal des Sciences naturelles de Belgique, Bruxelles 27(41): 1-20.

Received December 1, 2016, accepted August 1, 2017, published October 20, 2017 